\title{
Biodetection Technologies for First Responders
}

\author{
C Baird \\ D Seiner \\ R Ozanich \\ R Bartholomew
}

H Colburn

T Straub

C Bruckner-Lea

November 2012

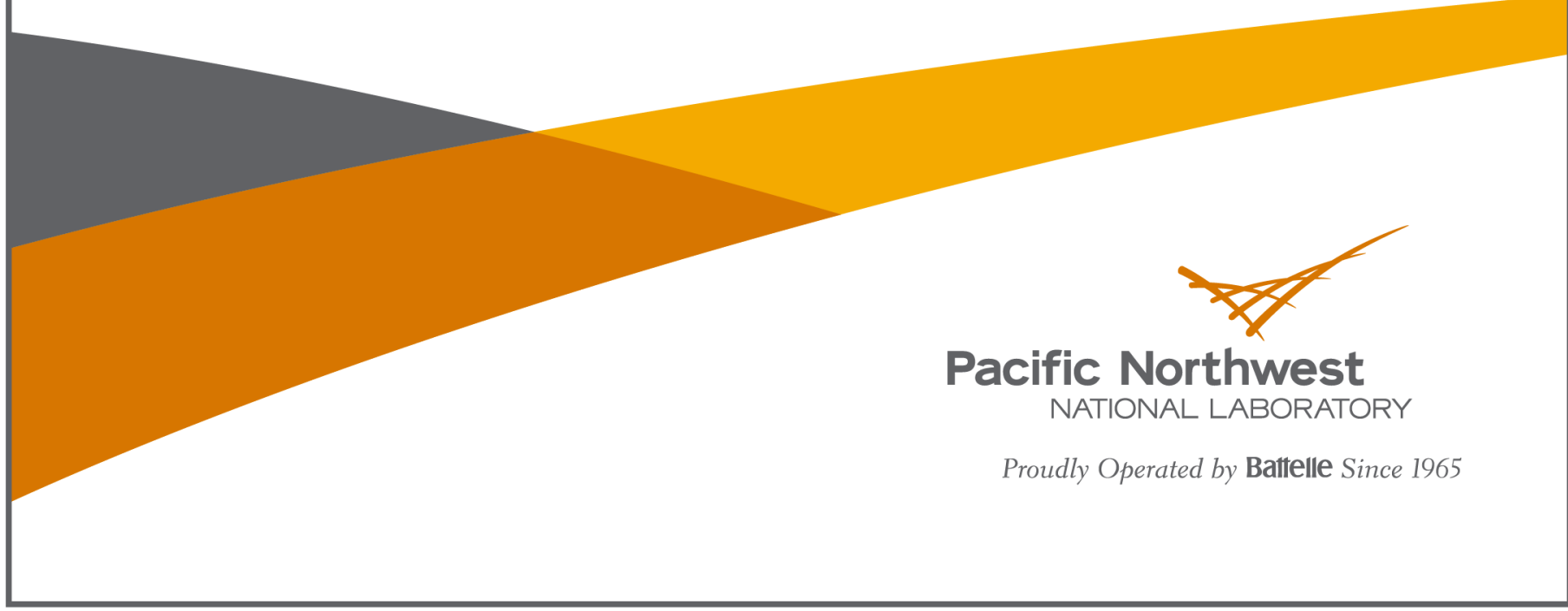


This report was prepared for the Department of Homeland Security Science and Technology Directorate under Contract HSHQDC-08-X-00843.

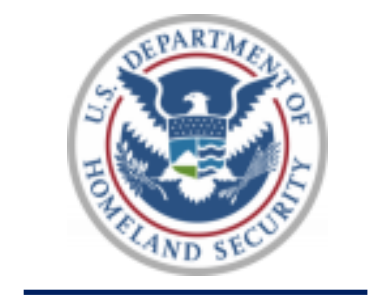

Science and Technology

\title{
DISCLAIMER
}

This report was prepared as an account of work sponsored by an agency of the United States Government. Neither the United States Government nor any agency thereof, nor Battelle Memorial Institute, nor any of their employees, makes any warranty, express or implied, or assumes any legal liability or responsibility for the accuracy, completeness, or usefulness of any information, apparatus, product, or process disclosed, or represents that its use would not infringe privately owned rights. Reference herein to any specific commercial product, process, or service by trade name, trademark, manufacturer, or otherwise does not necessarily constitute or imply its endorsement, recommendation, or favoring by the United States Government or any agency thereof, or Battelle Memorial Institute. The views and opinions of authors expressed herein do not necessarily state or reflect those of the United States Government or any agency thereof.

\author{
PACIFIC NORTHWEST NATIONAL LABORATORY \\ operated by BATTELLE for the \\ UNITED STATES DEPARTMENT OF ENERGY \\ under Contract DE-ACO5-76RL01830
}


PNNL-21713

\title{
Biodetection Technologies for First Responders
}

\author{
C Baird \\ H Colburn \\ D Seiner \\ T Straub \\ R Ozanich \\ C Bruckner-Lea \\ R Bartholomew
}

November 2012

Prepared for the Department of Homeland Security Science and Technology Directorate under Contract HSHQDC-08-X-00843.

Pacific Northwest National Laboratory

Richland, Washington 99352 



\section{Summary}

In a white powder scenario, a large variety of field-deployable assays can be used to determine if the suspicious substance contains biological material and warrants further investigation. First responders have several significant factors to consider before purchasing biodetection technologies, including:

- ease-of-use in the field

- weight and size

- total time from sample to answer

- type, usefulness, and accuracy of results

- total cost of ownership (e.g., hardware, consumables, and training needs) understanding that the reagent cost, shelf-life, instrument maintenance, and upgrades are significant contributors.

This report summarizes commercially-available, hand-portable technologies that can be used by first responders in the field. This is not meant to be an exhaustive list, nor an endorsement of any technology described herein. Rather, this report is meant to provide useful information about available technologies to help end-users make informed decisions about biodetection technology procurement and use. Information listed in this report is primarily vendor-provided; however, where possible it has been supplemented with additional information obtained from publications, reports, and websites. Manufacturers were given the chance to review summaries of their technologies from August through November 2012 to verify the accuracy of technical specifications, available references, and pricing.

Comparing biodetection technologies is challenging in the absence of independent, standardized, third-party testing. Many factors can impact measured performance metrics such as sensitivity (limit of detection) and selectivity (cross-reactivity). Environmental conditions, sample type, target threat agent, and degree of sample preparation all impact a technology's performance and make it difficult, if not impossible, to directly compare data generated for different technologies tested under different (and typically not well-defined) conditions. Vendor-provided performance metrics are listed, and where possible, shown in relation to the quantity (rather than concentration) of organism detected, because different technologies require different sample volumes (which ultimately affects the sensitivity of a test). Where possible, publicly available, peer-reviewed publications that evaluate the performance of a technology have been used; however, such publications are rare and often outdated. Available references are listed along with a short summary of findings and the technology's applicability for testing solid samples (e.g., powders).

This report has been organized based on grouping similar technologies relevant to investigating potential biological threat incidents. These include the following:

- sample collection kits

- non-specific assays including protein, adenosine triphosphate (ATP), deoxyribonucleic acid (DNA), and spectroscopic assays

- immunoassays

- polymerase chain reaction (PCR)-based detection systems.

Table ES.1 provides an overview of the technologies described in this report, including the product, manufacturer, website, cost, and applicable notes. 

Table ES.1. Overview of Products for Sampling and Detection of Potential Biothreats

\begin{tabular}{|c|c|c|c|c|c|}
\hline Instrument/Kit & Manufacturer & Company Website & Type of Assay & Cost & Notes \\
\hline $\begin{array}{l}\text { Alexeter Collection } \\
\text { Swab }\end{array}$ & Alexeter & http://www.alexeter.com/biow/index.asp & Sampling Kit & $\begin{array}{l}\$ 75 / \mathrm{box} \\
\text { of } 25\end{array}$ & $\begin{array}{l}\text { compatible with PCR and } \\
\text { immunoassay }\end{array}$ \\
\hline $\begin{array}{l}\text { Sample Collection and } \\
\text { Recovery Device (SCRD) }\end{array}$ & ASD BioSystems & http://www.asdbiosystems.com/p1.htm & Sampling Kit & $\$ 12$ each & $\begin{array}{l}\text { compatible with PCR and } \\
\text { immunoassay }\end{array}$ \\
\hline SWIPETM Kits & $\begin{array}{l}\text { New Horizons } \\
\text { Diagnostics }\end{array}$ & http://www.nhdiag.com/profile_one.shtml & Sampling Kit & $\begin{array}{c}\text { Kit } \\
\text { dependent } \\
\$ 13.20- \\
23.10\end{array}$ & $\begin{array}{l}\text { compatible with PCR and } \\
\text { immunoassay }\end{array}$ \\
\hline $\begin{array}{l}\text { B2C тм Bulk Sample } \\
\text { Collection Kit }\end{array}$ & $\begin{array}{l}\text { QuickSilver } \\
\text { Analytics, Inc. }\end{array}$ & http://www.chembiokits.com/ & Sampling Kit & $\begin{array}{l}\$ 26.71 \\
\text { each }\end{array}$ & $\begin{array}{l}\text { meets American Society for Testing } \\
\text { and Materials (ASTM) Standard E } \\
\text { 2458-10 for bulk sample collection }\end{array}$ \\
\hline $\begin{array}{l}\text { Biological Sampling Kit } \\
\left.\text { (BiSKit }^{\mathrm{TM}}\right) \text { - Large Area }\end{array}$ & $\begin{array}{l}\text { QuickSilver } \\
\text { Analytics, Inc. }\end{array}$ & http://www.chembiokits.com/ & Sampling Kit & $\begin{array}{l}\$ 31.50 \\
\text { each }\end{array}$ & $\begin{array}{l}\text { large area sampling kit compatible } \\
\text { with PCR and immunoassay }\end{array}$ \\
\hline $\begin{array}{l}\text { QSA Model } 102^{\mathrm{TM}} \text { Full } \\
\text { Forensic Analytical } \\
\text { Center (FAC) }\end{array}$ & $\begin{array}{l}\text { QuickSilver } \\
\text { Analytics, Inc. }\end{array}$ & http://www.chembiokits.com/ & Sampling Kit & $\begin{array}{l}\$ 2961.80 \\
\text { each }\end{array}$ & $\begin{array}{l}\text { large area sampling kit developed and } \\
\text { used by U.S. Army Mobile Labs and } \\
\text { Kits Team }\end{array}$ \\
\hline $\begin{array}{l}\text { Mini Push Pack }{ }^{\mathrm{TM}} \text { Kits } \\
\text { Wipe/Bio/Solid/Liquid }\end{array}$ & $\begin{array}{l}\text { QuickSilver } \\
\text { Analytics, Inc. }\end{array}$ & http://www.chembiokits.com/ & Sampling Kit & $\begin{array}{c}\$ 36.70 \\
\text { each }\end{array}$ & single-use kits \\
\hline $\begin{array}{l}\text { Small Area Sampling } \\
\left(\mathrm{SAS}^{\mathrm{TM}}\right) \mathrm{Kit}\end{array}$ & $\begin{array}{l}\text { QuickSilver } \\
\text { Analytics, Inc. }\end{array}$ & http://www.chembiokits.com/ & Sampling Kit & $\begin{array}{l}\$ 17.96 \\
\text { each }\end{array}$ & $\begin{array}{l}\text { designed for small area sampling; } \\
\text { 4-year shelf-life }\end{array}$ \\
\hline S3' ${ }^{\text {TM }}$ Bio Sampler & $\begin{array}{l}\text { QuickSilver } \\
\text { Analytics, Inc. }\end{array}$ & http://www.chembiokits.com/ & Sampling Kit & $\begin{array}{l}\$ 22.56 \\
\text { each }\end{array}$ & $\begin{array}{l}\text { Phosphate buffered saline (PBS) } \\
\text { buffer-moistened sponge for } \\
\text { sampling; compatible with PCR and } \\
\text { immunoassay }\end{array}$ \\
\hline $\mathrm{LiNK}{ }^{\odot}$ & $\begin{array}{l}\text { Triarii Scientific, } \\
\text { LLC }\end{array}$ & $\underline{\text { http://www.tri-sci.com/Link2.html }}$ & Sampling kit & $\$ 55$ each & $\begin{array}{l}\text { removes some PCR inhibitors; not } \\
\text { compatible with immunoassay }\end{array}$ \\
\hline HAZCAT WMD Kit & $\begin{array}{l}\text { HazTech } \\
\text { Systems }\end{array}$ & http://www.hazcat.com & Assorted & $\$ 4,910.17$ & $\begin{array}{l}\text { an all-in-one chemical/biological/ } \\
\text { radiological/nuclear/explosive } \\
\text { detection and classification kit }\end{array}$ \\
\hline Prime Alert ${ }^{\circledR}$ & GenPrime & http://www.genprime.com/ & $\begin{array}{l}\text { Non-Specific } \\
\text { Biological } \\
\text { (DNA) }\end{array}$ & $\begin{array}{l}\$ 12,000 \\
\text { reader; } \\
\$ 200 / \text { test }\end{array}$ & $\begin{array}{l}\text { non-specific DNA colorimetric test } \\
\text { with a separate immunoassay toxin } \\
\text { test }\end{array}$ \\
\hline
\end{tabular}


Table ES.1. (continued)

\begin{tabular}{|c|c|c|c|c|c|}
\hline Instrument/Kit & Manufacturer & Company Website & Type of Assay & Cost & Notes \\
\hline $\begin{array}{l}\text { BioCheck }^{\circledR} \text { Powder } \\
\text { Screening Kit }\end{array}$ & $\begin{array}{c}20 / 20 \\
\text { Bioresponse }\end{array}$ & http://biocheckinfo.com/ & $\begin{array}{c}\text { Non-Specific } \\
\text { Biological } \\
\text { (Protein \& pH) }\end{array}$ & $\begin{array}{l}\$ 687.50 / \\
25 \text { kits }\end{array}$ & $\begin{array}{l}\text { non-specific colorimetric protein } \\
\text { detection and } \mathrm{pH} \text { test }\end{array}$ \\
\hline Indipro & Macherey-Nagel & $\underline{\text { http://www.mn- }} \underline{\underline{\text { net.com/tabid/10441/default.aspx }}}$ & $\begin{array}{l}\text { Non-Specific } \\
\text { Biological } \\
\text { (Protein) }\end{array}$ & $\begin{array}{l}\$ 103 / \\
50 \text { strips }\end{array}$ & non-specific protein detection \\
\hline Profile $^{\circledR} 1$ & $\begin{array}{l}\text { New Horizons } \\
\text { Diagnostics }\end{array}$ & http://www.nhdiag.com/profile_one.shtml & $\begin{array}{l}\text { Non-Specific } \\
\text { Biological } \\
\text { (ATP) }\end{array}$ & $\begin{array}{l}\$ 5000 \\
\text { reader: } \\
\$ 450 / 100 \\
\text { tests }\end{array}$ & $\begin{array}{l}\text { non-specific test for live bacterial } \\
\text { cells using ATP }\end{array}$ \\
\hline HazMatID $^{\text {TM }} 360$ & Smiths Detection & http://www.smithsdetection.com & $\begin{array}{c}\text { Non-Specific } \\
\text { Biological } \\
\text { (FT-IR/Protein) }\end{array}$ & $\$ 53,000$ & $\begin{array}{l}\text { non-specific test for biological } \\
\text { material (protein-based) using FT-IR } \\
\text { spectroscopy }\end{array}$ \\
\hline HazMatID Ranger ${ }^{\mathrm{TM}}$ & Smiths Detection & http://www.smithsdetection.com & $\begin{array}{l}\text { Non-Specific } \\
\text { Biological } \\
\text { (FT-IR/Protein) }\end{array}$ & $\$ 35,000$ & $\begin{array}{l}\text { non-specific test for biological } \\
\text { material (protein-based) using FT-IR } \\
\text { spectroscopy }\end{array}$ \\
\hline HazMatID $^{\mathrm{TM}}$ Elite & Smiths Detection & http://www.smithsdetection.com & $\begin{array}{c}\text { Non-Specific } \\
\text { Biological } \\
\text { (FT-IR/Protein) }\end{array}$ & $\$ 50,000$ & $\begin{array}{l}\text { non-specific test for biological } \\
\text { material (protein-based) using FT-IR } \\
\text { spectroscopy }\end{array}$ \\
\hline TruDefenderTM FT/FTi & $\begin{array}{c}\text { Thermo } \\
\text { Scientific } \\
\text { (formerly Ahura } \\
\text { Scientific) }\end{array}$ & http://www.thermoscientific.com & $\begin{array}{l}\text { Non-Specific } \\
\text { Biological } \\
\text { (FT-IR/Protein) }\end{array}$ & $\begin{array}{l}\$ 45,000- \\
\$ 46,500\end{array}$ & $\begin{array}{l}\text { non-specific test for biological } \\
\text { material (protein-based) using FT-IR } \\
\text { spectroscopy }\end{array}$ \\
\hline $\begin{array}{l}\text { BADD }^{\mathrm{TM}} \text { Biowarfare } \\
\text { Agent Detection Devices }\end{array}$ & Advnt & http://www.advnt.org & Immunoassay & $\begin{array}{l}\$ 24.50 / \\
\text { test }\end{array}$ & $\begin{array}{l}\text { single-agent lateral flow } \\
\text { immunoassay }\end{array}$ \\
\hline Pro Strips ${ }^{\mathrm{TM}}$ & Advnt & http://www.advnt.org & Immunoassay & $\begin{array}{l}\$ 699.50 / \\
10 \text { tests }\end{array}$ & five-agent lateral flow immunoassay \\
\hline BioDetect $^{\mathrm{TM}}$ Test Strips & Alexeter & $\underline{\mathrm{http}: / / \mathrm{www} . \text { alexeter.com/biow/products.asp }}$ & Immunoassay & $\begin{array}{l}\$ 685 / \\
25 \text { tests }\end{array}$ & $\begin{array}{l}\text { single-agent lateral flow } \\
\text { immunoassay }\end{array}$ \\
\hline $\begin{array}{l}\text { Defender TSR }{ }^{\mathrm{TM}} \text { reader } \\
\text { for use with BioDetect } \\
\text { Test Strips }\end{array}$ & Alexeter & http://www.alexeter.com/biow/products.asp & $\begin{array}{l}\text { Immunoassay } \\
\text { reader }\end{array}$ & $\begin{array}{l}\$ 6500 \\
\text { reader }\end{array}$ & $\begin{array}{l}\text { handheld optical reader for single- } \\
\text { agent BioDetect } \\
\text { Windows test strips using } \\
\text { Wobile interface }\end{array}$ \\
\hline
\end{tabular}


Table ES.1. (continued)

\begin{tabular}{|c|c|c|c|c|c|}
\hline Instrument/Kit & Manufacturer & Company Website & Type of Assay & Cost & Notes \\
\hline $\begin{array}{l}\text { Guardian Reader }{ }^{\mathrm{TM}} \text { for } \\
\text { use with BioDetect } \\
\text { Test Strips }\end{array}$ & Alexeter & http://www.alexeter.com/biow/products.asp & $\begin{array}{l}\text { Immunoassay } \\
\text { reader }\end{array}$ & $\begin{array}{l}\$ 9995 \\
\text { reader }\end{array}$ & $\begin{array}{l}\text { optical reader for single-agent } \\
\text { BioDetect }\end{array}$ \\
\hline RAID $^{\text {TM }}$ Multi-Test Strips & Alexeter & http://www.alexeter.com/biow/products.asp & Immunoassay & $\begin{array}{l}\$ 695- \\
\$ 995 / \\
10 \text { tests }\end{array}$ & $\begin{array}{l}\text { multiplexed lateral flow immunoassay } \\
\text { available as either five-plex or eight- } \\
\text { plex }\end{array}$ \\
\hline ENVI Assay System & Environics & http://www.environicsusa.com & Immunoassay & $\begin{array}{l}\$ 400- \\
\$ 450 / \\
10 \text { tests }\end{array}$ & $\begin{array}{l}\text { toxin assays can be read visually or } \\
\text { with a reader }(\$ 3452) \text {, while the } \\
\text { ENVI-FL pathogen assays require a } \\
\text { reader }\end{array}$ \\
\hline BIOSENSOR $^{\text {TM }} 2200 \mathrm{R}$ & MSA/QTL & http://www.msafire.com/ & $\begin{array}{l}\text { Immunoassay, } \\
\text { automated }\end{array}$ & $\begin{array}{l}\$ 16,450 \\
\$ 80 / \text { single } \\
\text {-agent test }\end{array}$ & $\begin{array}{l}\text { fluorescence-based automated } \\
\text { immunoassay detection system }\end{array}$ \\
\hline Smart $^{\mathrm{TM}} \mathrm{II}$ & $\begin{array}{l}\text { New Horizons } \\
\text { Diagnostics }\end{array}$ & $\underline{\text { http://www.nhdiag.com/profile_one.shtml }}$ & Immunoassay & $\begin{array}{c}\$ 550 / \\
25 \text { tests }\end{array}$ & $\begin{array}{l}\text { single-agent lateral flow } \\
\text { immunoassay strips }\end{array}$ \\
\hline RAMP $^{\circledR}$ & $\begin{array}{l}\text { Response } \\
\text { Biomedical }\end{array}$ & http://www.responsebio.com & $\begin{array}{l}\text { Immunoassay } \\
\text { and reader }\end{array}$ & $\begin{array}{l}\$ 11,333 \\
\$ 27 / \text { test } \\
\text { (anthrax) }\end{array}$ & $\begin{array}{l}\text { fluorescence-based lateral flow } \\
\text { immunoassay strips and reader }\end{array}$ \\
\hline $\begin{array}{l}\text { RAPTORTM: Portable, } \\
\text { Multianalyte Bioassay } \\
\text { Detection System }\end{array}$ & $\begin{array}{l}\text { Research } \\
\text { International }\end{array}$ & http://resrchintl.com/ & $\begin{array}{l}\text { Immunoassay, } \\
\text { automated }\end{array}$ & $\begin{array}{l}\$ 50,000 \\
\$ 200 / \text { test }\end{array}$ & $\begin{array}{l}\text { portable automated immunoassay } \\
\text { system designed for the U.S. military }\end{array}$ \\
\hline $\mathrm{NIDS}^{\mathrm{TM}}$ & $\begin{array}{c}\text { ANP } \\
\text { Technologies/Sm } \\
\text { iths Detection }\end{array}$ & http://www.smithsdetection.com/NIDS.php & $\begin{array}{l}\text { Immunoassay } \\
\text { and reader }\end{array}$ & $\begin{array}{c}\$ 7500 \\
\$ 45- \\
\$ 75 / \text { assay }\end{array}$ & $\begin{array}{l}\text { multiplexed lateral flow immunoassay } \\
\text { with optical reader }\end{array}$ \\
\hline $\begin{array}{l}\text { BioThreat Alert }{ }^{\circledR} \text { and } \\
\text { Reader }\end{array}$ & Tetracore & http://www.tetracore.com/bio-warfare/ & $\begin{array}{l}\text { Immunoassay } \\
\text { and reader }\end{array}$ & $\begin{array}{l}\$ 5500 \\
\$ 605 / \mathrm{box} \\
\text { of } 25\end{array}$ & $\begin{array}{l}\text { single-agent lateral flow } \\
\text { immunoassay with optical reader }\end{array}$ \\
\hline FilmArray ${ }^{\circledR}$ & $\begin{array}{c}\text { BioFire } \\
\text { Diagnostics } \\
\text { (formerly Idaho } \\
\text { Technology) }\end{array}$ & http://www.biofiredx.com & PCR & $\begin{array}{l}\$ 49,500 \\
\$ 180 \\
\text { pouch }\end{array}$ & $\begin{array}{l}\text { sample-to-answer PCR system, } \\
\text { detects } 21 \text { targets per pouch }\end{array}$ \\
\hline R.A.P.I.D. ${ }^{\circledR}($ JBAIDS $)$ & $\begin{array}{l}\text { BioFire } \\
\text { Diagnostics } \\
\text { (formerly Idaho } \\
\text { Technology) }\end{array}$ & http://www.biofiredx.com & PCR & $\begin{array}{l}\$ 55,000 \\
\$ 452 / 48 \\
\text { assays }\end{array}$ & $\begin{array}{l}\text { portable PCR system designed for the } \\
\text { U.S. Military; multiple assays } \\
\text { available }\end{array}$ \\
\hline
\end{tabular}


Table ES.1. (continued)

\begin{tabular}{|c|c|c|c|c|c|}
\hline Instrument/Kit & Manufacturer & Company Website & Type of Assay & Cost & Notes \\
\hline RAZOR $^{\circledR}$ EX & $\begin{array}{c}\text { BioFire } \\
\text { Diagnostics } \\
\text { (formerly Idaho } \\
\text { Technology) }\end{array}$ & http://www.biofiredx.com & PCR & $\begin{array}{c}\$ 38,500 \\
\$ 200 \\
\text { pouch }\end{array}$ & $\begin{array}{l}\text { portable PCR system detects } \\
10 \text { targets per pouch }\end{array}$ \\
\hline Bio-Seeq ${ }^{\text {TM }}$ PLUS & Smiths Detection & http://www.smithsdetection.com & PCR & $\begin{array}{l}\$ 45,000 \\
\$ 30 / \text { assay }\end{array}$ & $\begin{array}{l}\text { portable PCR system, uses single- } \\
\text { agent assays }\end{array}$ \\
\hline $\mathrm{T}-\mathrm{COR} 4^{\mathrm{TM}}$ & Tetracore & http://www.tetracore.com/t-cor/index.html & PCR & $\begin{array}{c}\$ 16,000 \\
\$ 12 \\
\text { cartridge }\end{array}$ & $\begin{array}{l}\text { portable PCR system, uses single- } \\
\text { agent assays }\end{array}$ \\
\hline
\end{tabular}




\section{Acronyms and Abbreviations}

ASTM

ATP

COTS

DNA

ECBC

EEE

EPA

ETV

FAC

FT-IR

HAZMAT

LFA

LOD

NHD

NIDS

NYDOH

PBS

PCR

PNNL

R.A.P.I.D.

RAMP

RNA

SCRD

SEB

SPADA

TNT

$\mathrm{UAB}$

WEE

WMD
American Society for Testing and Materials

adenosine triphosphate

commercial-off-the-shelf

deoxyribonucleic acid

Edgewood Chemical and Biological Center

Eastern Equine Encephalitis

U.S. Environmental Protection Agency

U.S. EPA Technology Verification

Forensic Analytical Center

Fourier Transform Infrared

hazardous materials

lateral flow assay

limit of detection

New Horizons Diagnostics

Nano Intelligent Detection System

New York State Department of Health

phosphate buffered saline

polymerase chain reaction

Pacific Northwest National Laboratory

Ruggedized Advanced Pathogen Identification Device

Rapid Analyte Measurement Platform

ribonucleic acid

sample collection and recovery device

Staphylococcal Enterotoxin B (toxin)

Stakeholder Panel on Agent Detection Assays

trinitrotoluene

University of Alabama

Western Equine Encephalitis

weapon of mass destruction 



\section{Contents}

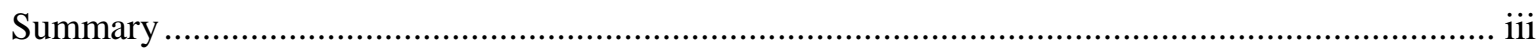

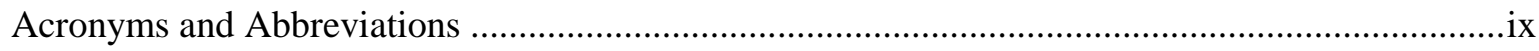

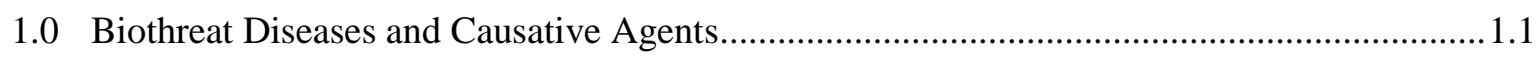

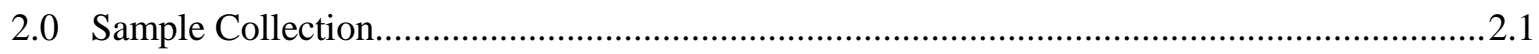

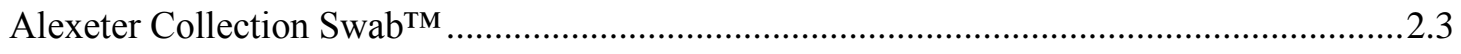

ASD Biosystems Sample Collection and Recovery Device ................................................. 2.4

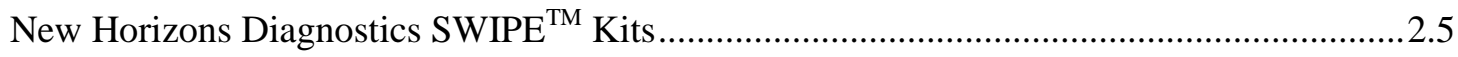

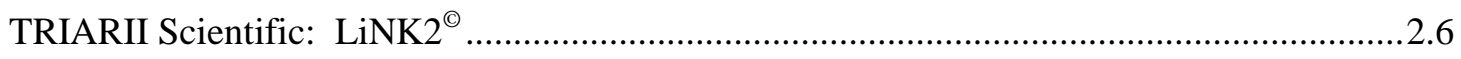

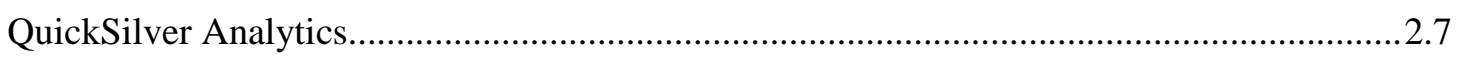

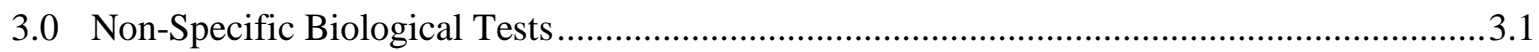

HazTech Systems: KT7001 HAZCAT WMD Kit.............................................................. 3.3

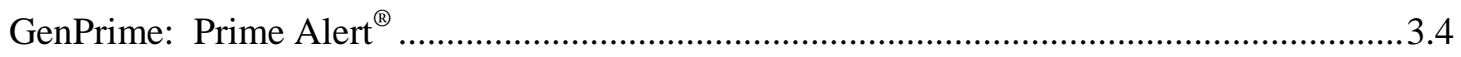

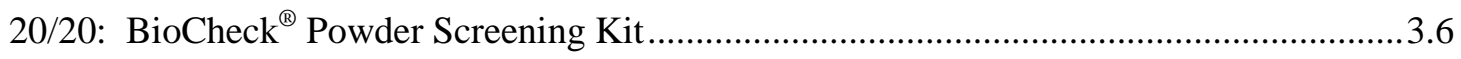

Macherey-Nagel Indipro: Protein Test Strips................................................................. 3.8

New Horizons Diagnostics PROFILE ${ }^{\circledR} 1$ : ATP Test............................................................ 3.9

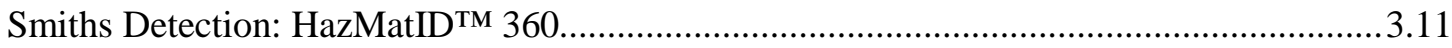

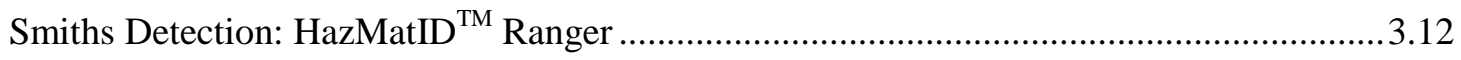

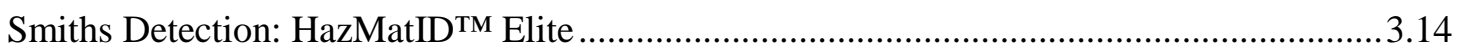

Thermo Scientific (Formerly Ahura): TruDefender ${ }^{\circledR}$ FT and FTi ........................................16

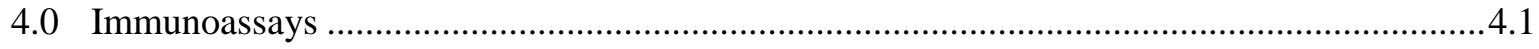

Advnt: BADD ${ }^{\mathrm{TM}}$ Biowarfare Agent Detection Devices...................................................... 4.3

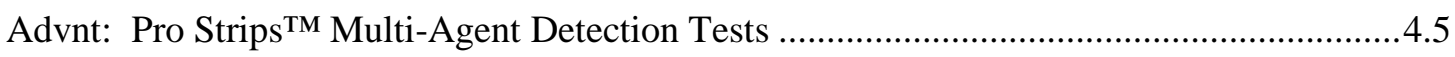

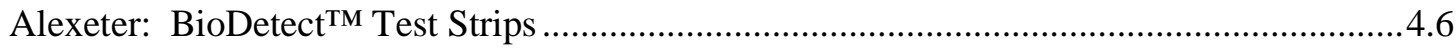

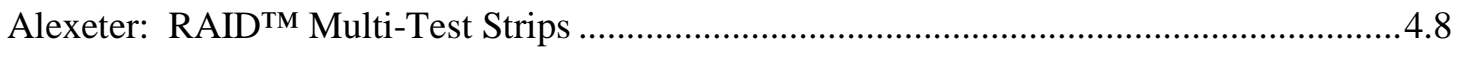

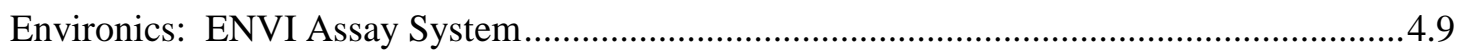

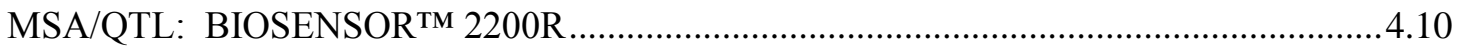

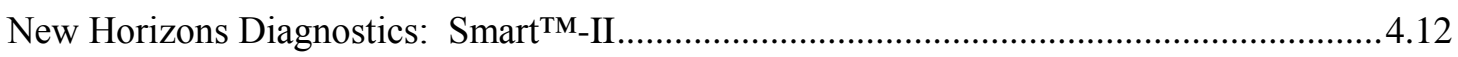

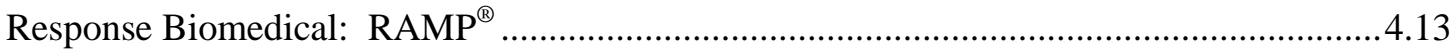

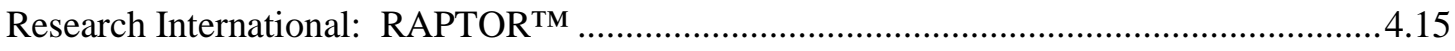

Smiths Detection: NIDSTM (Developed by ANP Technologies) ...........................................17

Tetracore: BioThreat Alert ${ }^{\circledR}$ Test Strips and Reader .........................................................18

5.0 PCR-Based Detection Systems .....................................................................................

BioFire Diagnostics (formerly Idaho Technology): FilmArray ${ }^{\circledR}$.............................................. 5.3

BioFire Diagnostics (formerly Idaho Technology): R.A.P.I.D. ${ }^{\circledR}$...........................................5.5

BioFire Diagnostics (formerly Idaho Technology): RAZOR ${ }^{\circledR}$ EX …….................................. 5.7

Smiths Detection: Bio-Seeq ${ }^{\text {TM }}$ PLUS ……................................................................. 5.9

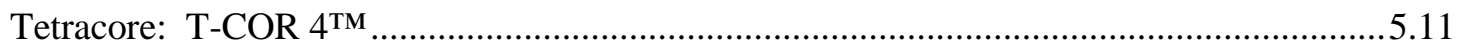




\section{Tables}

ES.1 Overview of Products for Sampling and Detection of Potential Biothreats............................ v v

1.1 Listing of Diseases and Toxins Referenced in this Report with Their Causative Agents or

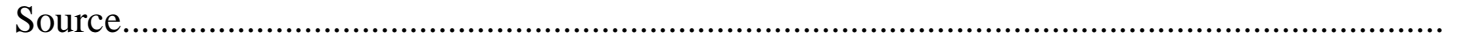

1.1 


\subsection{Biothreat Diseases and Causative Agents}

Important Note: Biothreat detection target names used throughout this report are those specified by equipment manufacturers. Often, vendors reference a disease instead of its causative agent. One prevalent example is the use of anthrax, a disease caused by the organism Bacillus anthracis (B. anthracis). These tests detect the organism, not the disease, yet anthrax and B. anthracis are used interchangeably in the biodetection technology marketplace. Table 1.1 lists diseases and their corresponding biothreat agents.

Table 1.1. Causative Agents or Sources for Various Diseases and Toxins

\begin{tabular}{ll}
\hline \multicolumn{1}{c}{ Disease/Toxin } & \multicolumn{1}{c}{ Causative Agent/Source } \\
\hline Anthrax & Bacillus anthracis \\
Plague & Yersinia pestis \\
Tularemia & Francisella tularensis \\
Smallpox & Orthopoxvirus (Variola virus) \\
Brucellosis & Brucella species \\
Typhus & Rickettsia prowazekii \\
Viral encephalitis & Alphaviruses (Western Equine Encephalitis \\
& [WEE], Venezuelan Equine Encephalitis [VEE], \\
Viral hemorrhagic fevers & and Eastern Equine Encephalitis [EEE]) \\
Q fever & Marburg and Ebola Viruses \\
Melioidosis & Coxiella burnetii \\
Glanders & Burkholderia pseudomallei \\
Foodborne illness & Burkholderia mallei \\
Ricin toxin & Salmonella species, E. coli O157:H7, Shigella \\
Staphylococcal Enterotoxin B (SEB) toxin & Ricinus communis (Castor oil plant) \\
Botulism (botulinum toxin) & Staphylococcus aureus \\
\hline
\end{tabular}




\subsection{Sample Collection}

In addition to sampling kits provided as part of an assay kit, wide ranges of standalone sampling kits are available. Typically, these kits consist of a swab or scoop to pick up the sample and a collection vial with buffer to solubilize the sample. Additional features may include integrated droppers for sample dispensing, chain-of-custody forms, or sample preparation for removal of potential assay inhibitors. Most kits are designed to be dunked for decontamination, so that a sample can easily be sent out to a laboratory or tested in the warm or cold zone (near or outside of the contaminated area, respectively).

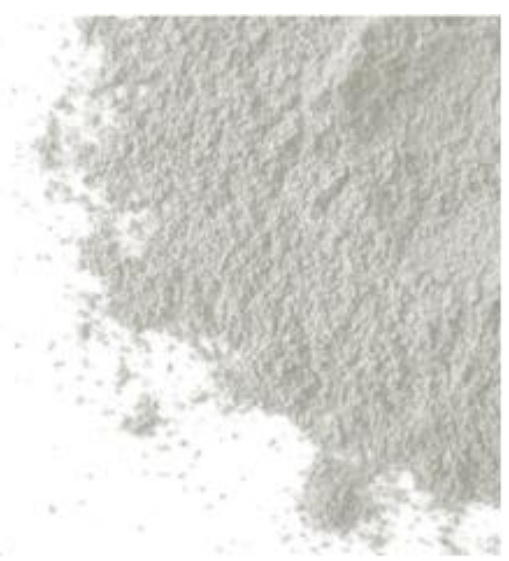

For the most part, the sampling kits listed in this report are designed to sample "white powders." With a few exceptions, no sample processing to remove potential assay inhibitors is employed. The kits are designed to suspend suspect material in a buffered solution for downstream analysis. Whereas the kits themselves have not been formally evaluated, principal components of the kits (e.g. swabs, wipes, and sponges) have been evaluated for their ability to recover Bacillus spp. spores from various surfaces (1-6). In some cases, the protocols and components provided in the kits are designed to meet standards for law enforcement/chain of custody requirements for the criminal investigation of a biological attack (7-9).

Most of the available literature on sampling materials concerns recovery efficiency. Recovery efficiency is affected by a number of factors including the sampling materials, surface area covered (1), inanimate surfaces (stainless steel, tile, carpet, drywall, etc.), how assayed, and even spore deposition (16). With these studies, it is important to emphasize that there is an underlying assumption that high spore/agent concentrations will be present in a small area. Unfortunately, due to the multifactorial nature of the sampling and preservation issues, the studies offer little consensus on best practices for sampling "white powders" from suspected incidents.

In summary, when choosing a sampling kit, the potential downstream diagnostic assays should be considered. Care should be exercised to insure that, especially when buffers are used, the final sample is compatible with the down-stream detection methods. For example, some sample buffers have components that can interfere with immunoassays or PCR-based detection systems. Always verify with the manufacturer that the sampling kit is compatible with the diagnostic assay and suitable for collection of the sample type of interest.

\section{References}

1. Buttner, M. P., P. Cruz, V. L. Stevens, and P. A. Emanuel. 2004. Evaluation of the Biological Sampling Kit (BiSKit) for large-area surface sampling. Appl Environ Microbiol 70:7040-7045.

2. Hodges, L. R., L. J. Rose, A. Peterson, J. Nobel-Wang, and M. J. Arduino. 2006. Evaluation of a macrofoam swab protocol for the recovery of Bacillus anthracis spores from a steel surface. Appl Environ Microbiol 72:4429 - 4430.

3. Rose, L. J., L. Hodges, H. O. O'Connell, and J. Nobel-Wang. 2011. National validation study of a cellulose sponge wipe-processing method for use after sampling Bacillus anthracis spores from surfaces. Appl Environ Microbiol 77:8355-8359. 
4. Valentine, N. B., M. G. Butcher, Y. F. Su, K. H. Jarman, M. Matzke, B. J. Webb-Robertson, E. A. Panisko, B. A. B. Seiders, and K. L. Wahl. 2008. Evaluation of sampling tools for environmental sampling of bacterial endospores from porous and nonporous surfaces. J Appl Microbiol 105:1107-1113.

5. Edmonds, J. M., P. J. Collett, E. R. Valdes, E. W. Skowronski, G. J. Pellar, and P. A. Emanuel. 2009. Surface sampling of spores in dry-deposition aerosols. Appl Environ Microbiol 75:39-44.

6. Rose, L., B. Jensen, A. Peterson, S. N. Banerjee, and M. J. Srduino. 2004. Swab materials and Bacillus anthracis spore recovery from nonporous surfaces. Emerg Infect Dis 10:1023-9.

7. Budowle, B., S. E. Schutzer, M. S. Ascher, R. M. Atlas, J. P. Burans, R. Chakraborty, J. J. Dunn, C. M. Fraser, D. R. Franz, T. J. Leighton, S. A. Morse, R. S. Murch, J. Ravel, D. L. Rock, T. R. Slezak, S. P. Velsko, A. C. Walsh, and R. A. Walters. 2005. Toward a system of microbial forensics: from sample collection to interpretation of evidence. Appl Environ Microbiol 71:2209-13.

8. Budowle, B., S. E. Schutzer, J. P. Burans, D. J. Beecher, T. A. Cebula, R. Chakraborty, W. T. Cobb, J. Fletcher, M. L. Hale, R. B. Harris, M. A. Heitkamp, F. P. Keller, C. Kuske, J. E. Leclerc, B. L. Marrone, T. S. McKenna, S. A. Morse, L. L. Rodriguez, N. B. Valentine, and J. Yadev. 2006. Quality sample collection, handling, and preservation for an effective microbial forensics program. Appl Environ Microbiol 72:6431-8.

9. Budowle, B., S. E. Schutzer, A. Einseln, L. C. Kelley, A. C. Walsh, J. A. Smith, B. L. Marrone, J. Robertson, and J. Campos. 2003. Public health. Building microbial forensics as a response to bioterrorism. Science 301:1852-3. 


\section{Alexeter Collection Swab ${ }^{\mathrm{TM}}$}

Website: http://www.alexeter.com/biow/index.asp

Contact: Tom Fryzel (tfryzel@alexeter.com)

Phone: (877) 591-5571

\section{Technology Summary}

The Alexeter Collection Swab ${ }^{\mathrm{TM}}$ combines onsite sampling of biological agents and sample preparation for fieldtesting by immunoassay or PCR-based assay. The device includes a Dacron ${ }^{\circledR}$-tipped swab, self-contained test buffer, pre-filter, and transfer sample dropper-all in one device. The all-in-one device minimizes sample transfer operations and is provided in a convenient single package.

\section{Compatibility with Biodetection Assays}

The Alexeter Collection Swab ${ }^{\mathrm{TM}}$ is designed to be used with Alexeter BioDetect immunoassay test strips. According to the company, the collection swab is compatible with PCR-based detection.

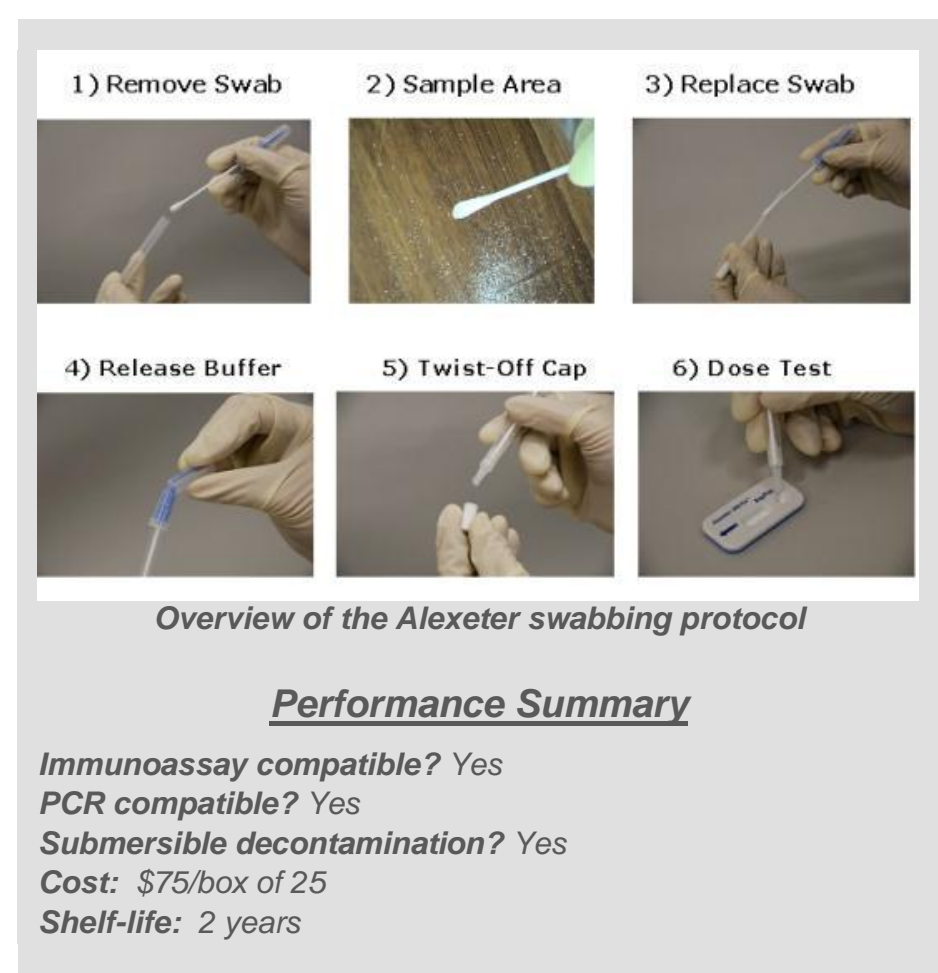

\section{References}

No publicly available, peer-reviewed literature references were found for this product. 


\section{ASD Biosystems Sample Collection and Recovery Device}

Website: http://www.asdbiosystems.com/p1.htm

Contact: ASD BioSystems, Inc. (info@asdbiosystems.com)

Phone: (804) 545-3102

\section{Technology Summary}

The ASD Biosystems Sample and Collection Recovery Device (SCRD) enables collection, transport, recovery, and retention of a specimen in a barcoded tube. The collection buffer is

determined by the end-user. The collection device is a conical tube containing a buffer solution with a swab attached to the lid. The company offers four standard collection buffers (Tris with $1 \%$ pluronic acid, phosphate buffered saline (PBS), Water, or PBS with $0.1 \%$ Tween-20), all of which are compatible with immunoassay or PCR-based detection systems. After a sample is taken, the swab is rinsed in buffer, and the sample assayed using the detection system of choice.

\section{Compatibility with Biodetection Assays}

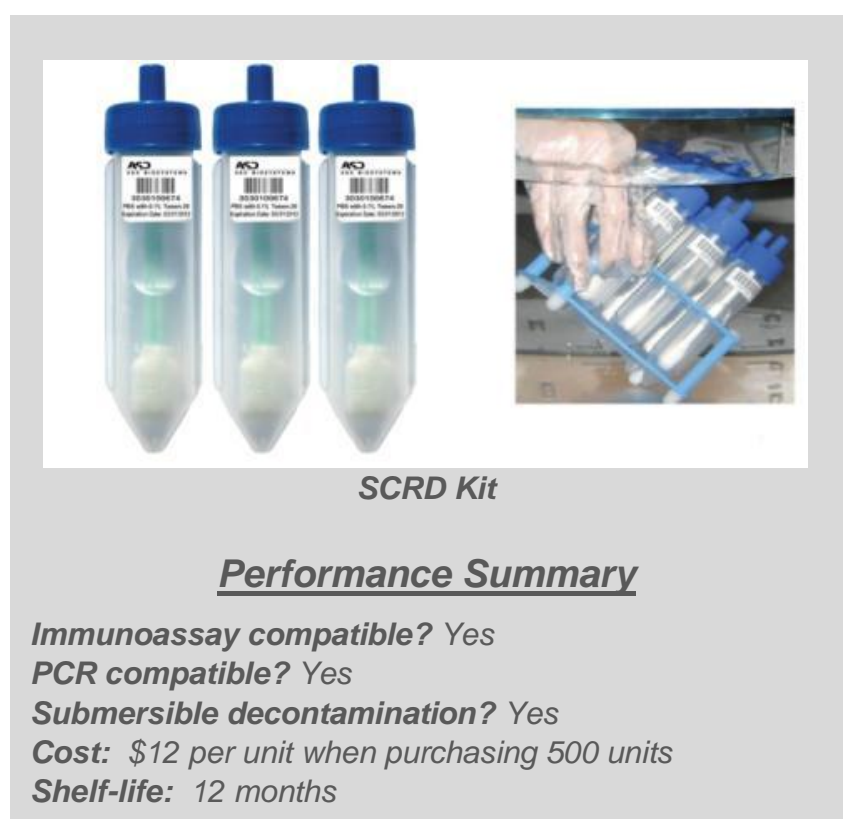

These collection devices can be used with immunoassay or PCR-based systems. Most of the available standard buffers offered by the company are compatible with both immunoassay and PCR-based detection.

\section{References}

No publicly available, peer-reviewed literature references were found for this product. 


\section{New Horizons Diagnostics SWIPE ${ }^{\mathrm{TM}}$ Kits}

Website: http://www.nhdiag.com/profile_one.shtml

Contact: Larry Loomis (larryl@nhdiag.com)

Phone: (443) 543-5755

\section{Technology Summary}

New Horizons Diagnostics SWIPE ${ }^{\mathrm{TM}}$ kits are prepackaged, sterilized sampling kits for the HAZMAT community. SWIPE ${ }^{\mathrm{TM}}$ kits are available in five different formats, all of which contain a slide lock bag for dunkable decontamination, if necessary, to remove the collected sample from the hot zone. SWIPE ${ }^{\mathrm{TM}} \mathrm{I}$ (\$23.10 each) is a large surface collection kit that comes with $25 \mathrm{~mL}$ of Aseptisol $^{\mathrm{TM}}$ collection fluid and an adenosine triphosphate (ATP)-free sponge. SWIPE ${ }^{\mathrm{TM}}$ II (\$23.10 each) is a smallsurface or powder collection kit, which includes a sterile spatula, collection tube, and two sterile swabs. SWIPE ${ }^{\mathrm{TM}}$ III (\$13.20 each) is a liquid collection kit with two sterile 10 mL syringes. SWIPE ${ }^{\mathrm{TM}} \mathrm{IV}$ ( $\$ 18.15$ each) is an aerosol on filter collection kit containing a sterile collection tube, $25 \mathrm{~mL}$ of Aseptisol ${ }^{\mathrm{TM}}$ collection fluid, and sterile forceps. $\mathrm{SWIPE}^{\mathrm{TM}}$ Sample Processing Kit (SPK) (\$17.33 each) is a kit designed to be used for sample dilution or pre-filtration of turbid samples outside the hot zone and includes syringes, collection tubes, $25 \mathrm{~mL}$ of Aseptisol ${ }^{\mathrm{TM}}$ fluid, and a biohazard bag for collection of waste.

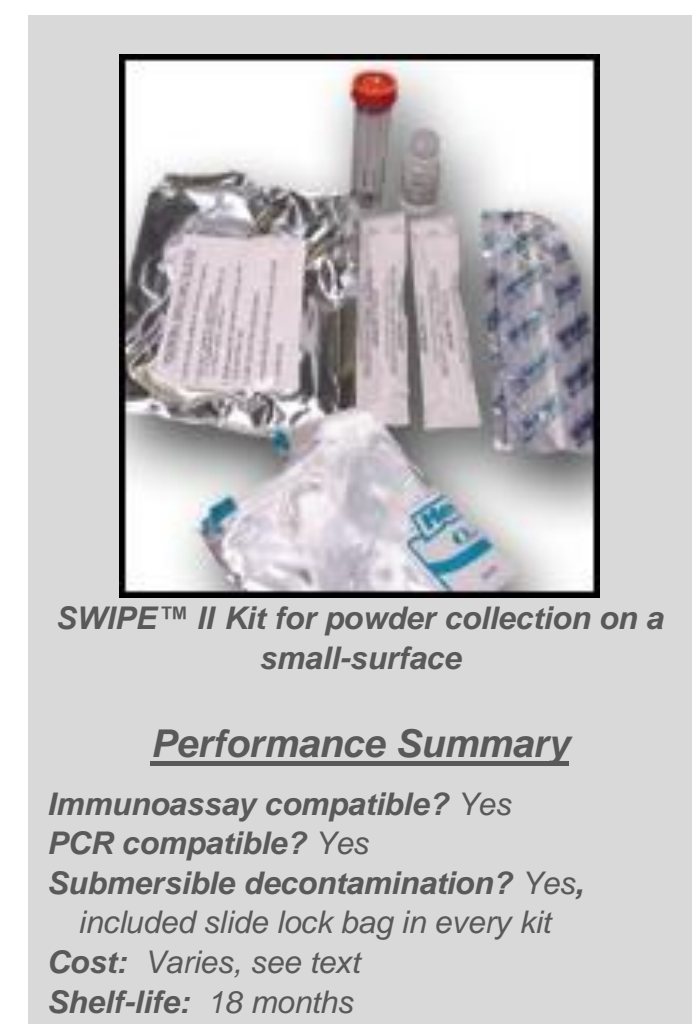

\section{Compatibility with Biodetection Assays}

These collection devices can be used with immunoassay or PCR-based detection systems.

\section{References}

No publicly available, peer-reviewed literature references were found for this product. 


\section{TRIARII Scientific: LiNK2 $^{\odot}$}

Website: http://www.tri-sci.com/index.html

Sales Contact: Jim Trecek (jtrecek@tri-sci.com)

Technical Contact: Ryan Deady (ryan.deady@qckslvr.com)

Phone: (918) 760-5533

\section{Technology Summary}

The LiNK $2^{\odot}$ is a sample-processing system specifically designed to prepare samples (wet or dry) for PCR-based detection. The system is used to collect, lyse, and purify biological samples, removing potential PCR inhibitors in the process. Removing PCR inhibitors may be critical for some sample types to reduce false negative results due to inactivation or inhibition of the enzyme reagents in the PCR assay, which may cause a false negative result.

The Massachusetts Institute of Technology Lincoln Laboratory and the Naval Medical Research Center have evaluated this sample-processing system. The results of these evaluations are reported by the manufacturer along with the conclusion that PCR assays using the LiNK $2^{\odot}$ collection solution perform at levels comparable to standard laboratory sample cleanup processes. The PCR systems evaluated in combination with $\mathrm{LiNK} 2^{\odot}$ sample preparation included the RAZOR ${ }^{\circledR}$ EX (BioFire Diagnostics), LightCycler ${ }^{\circledR}$

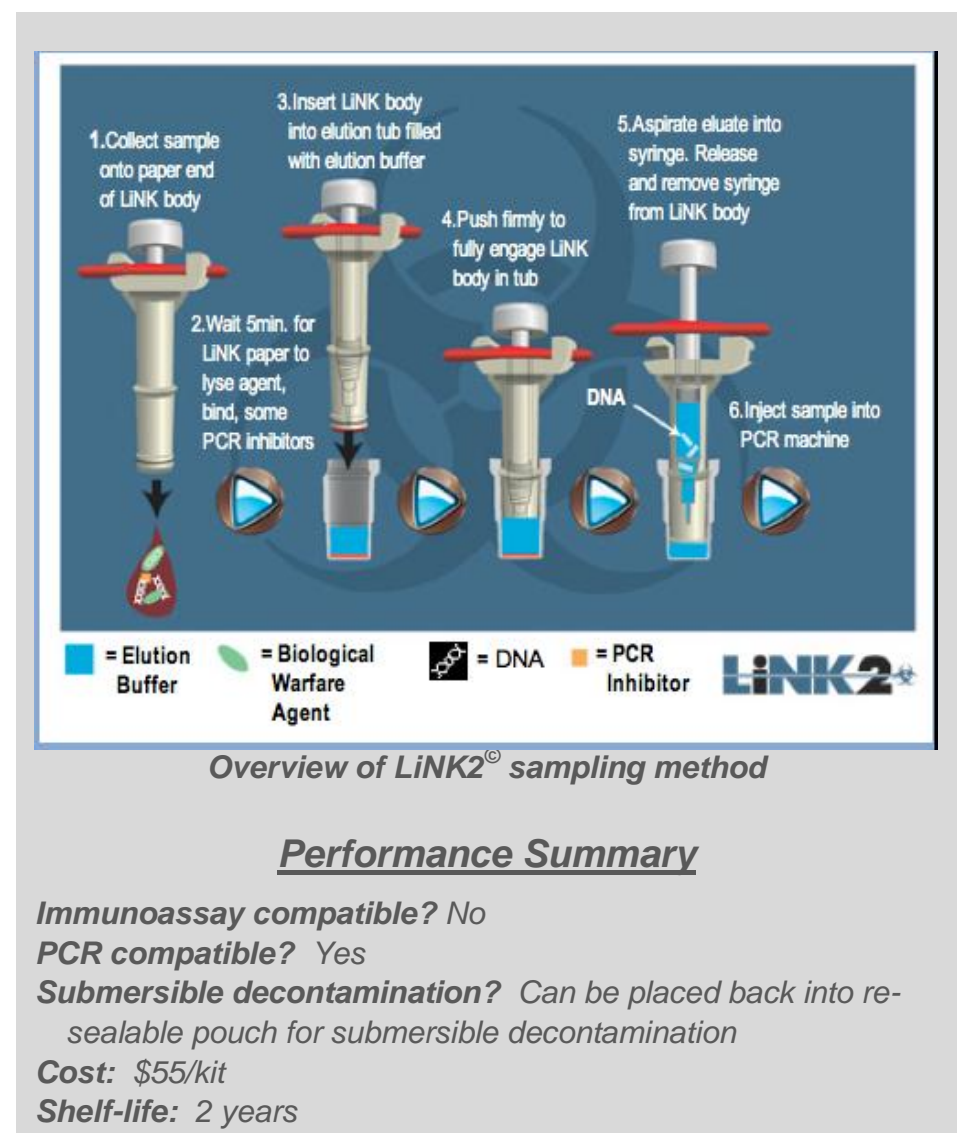
(Roche), and 7900 Fast Real-Time PCR System (Applied Biosystems).

\section{Compatibility with Biodetection Assays}

The LiNK $2^{\odot}$ system is designed to purify deoxyribonucleic acid (DNA) for PCR-based assays. This system is not recommended for immunoassays, because the sample processing may disrupt and/or remove the immunoassay targets.

\section{References}

No publicly available, peer-reviewed literature references were found for this product. 


\section{QuickSilver Analytics}

Website: http://chembiokits.com

Contact: Ryan Deady (ryan.deady@qukslvr.com)

Phone: (410) 676-4300

\section{Technology Summary}

QuickSilver Analytics, Inc. is ISO 9001-2008 registered and a Center for Veterans Enterprise-verified Service Disabled Veteran-Owned Small Business. The company specializes in sampling kits for the HazMat community. Several biological sampling kits with slightly different utility are reviewed here. All kits use PBS buffer for biological sampling, which is compatible with immunoassays and PCR-based systems. In addition, sample containers can be dunked for decontamination after sample collection.

- $3^{\mathrm{TM}}$ Bio Sampler (\$22.56 each). The S3 ${ }^{\mathrm{TM}}$ Bio Sampler is designed to collect biological samples from potentially contaminated surfaces onto a PBS buffermoistened sterilized sponge for field or laboratory analysis.

- Small Area Sampling (SAS ${ }^{\mathrm{TM}}$ ) Kit (\$17.96 each). The SAS $^{\text {TM }}$ Kit is intended to sample small areas. The kit includes two swabs that can be moistened with the provided buffer (4 mL PBS) for sampling of powders or used directly for liquids. The swab can be broken off into the buffer bottle, placed into the $50 \mathrm{~mL}$ centrifuge tube, and shipped in the plastic bag provided for transport to a lab for analysis. A chain-of-custody form is also included. This kit has a 4-year shelf-life from the date of manufacture.

- Biological Sampling Kit (BiSKit ${ }^{\mathrm{TM}}$ ) - Large Area Sampling Kit (\$31.50). The BiSKit ${ }^{\mathrm{TM}}$ is designed to sample $1 \mathrm{~m}^{2}$ of surface for bacteria, viruses, and toxins and to solubilize the sample in PBS buffer with sufficient volume $(15 \mathrm{~mL})$ for extensive testing and archiving. The kit has been designed to be easy to use in Level A protective gear and to enable transport of a sample without leaking. The lid of the unit has a foam material attached for collecting either a wet or a dry sample. After sampling, the lid is screwed back on and the unit can then be removed from the area for later testing or used for immediate analysis. This kit has a 2-

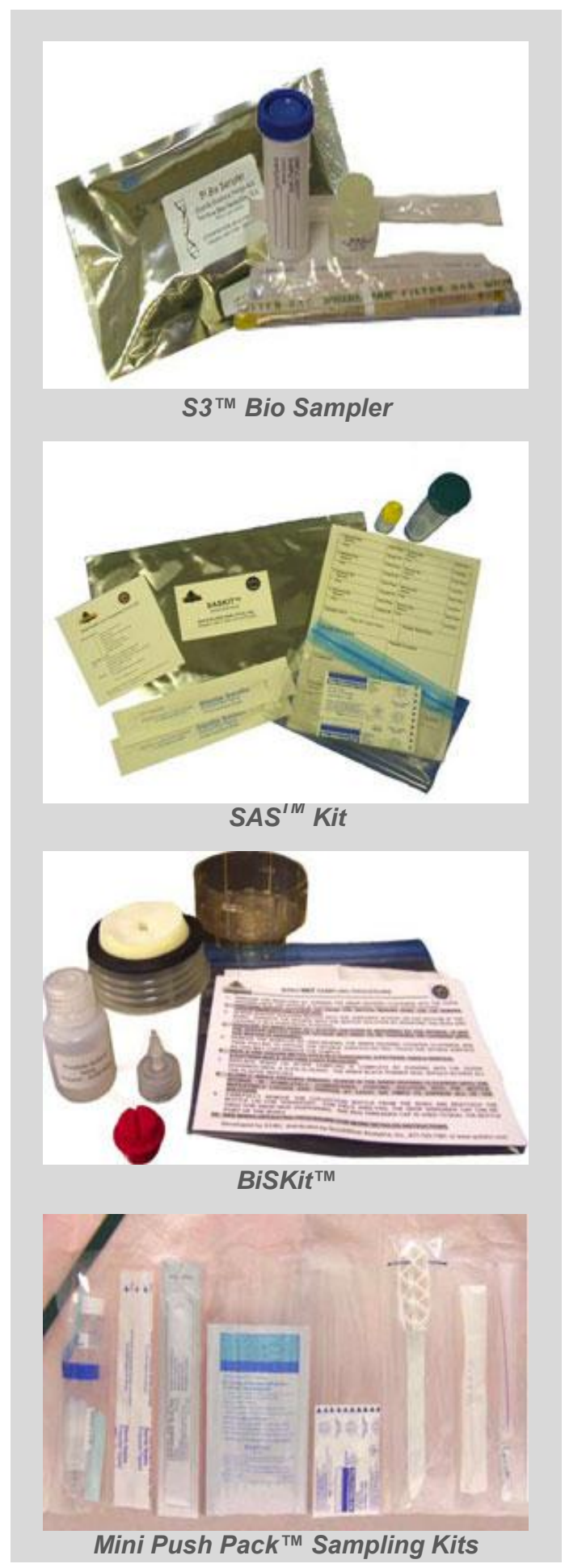


year shelf-life from date of manufacture.

- Mini Push Pack ${ }^{\mathrm{TM}}$ Sampling Kits:

- Wipe Sampling Kit (\$51.30)

- Biological Sampling Kit (\$36.70, pictured)

- Liquid Sampling Kit (\$84.50)

- Solid Sampling Kit (\$52.50)

These kits are highly compact and portable single-use units that contain the tools and supplies needed to take one sample per pack. All of the components are heat sealed into one package that is notched for easy opening. Each package is held together with a color-coded strap used to differentiate each type of sampling kit. Once sampling is complete, all of the waste can be placed on the absorbent liner, rolled up, and secured with the strap for disposal.

- QSA Model 102 ${ }^{\text {TM }}$ Full FAC (\$2961.80). This is a large sampling kit developed and used by the Edgewood Chemical and Biological Center (ECBC) Forensic Analytical Center (FAC) Mobile Labs Team. The kit (not shown) has materials for obtaining 27 total samples for chemical/biological/radiological/explosives testing.

- B2C ${ }^{\text {TM }}$ Bulk Sample Collection Kit - SWB60013 (\$26.71). This kit meets Method A of the ASTM Standard E 2458-10 for bulk sample collection and packaging of visible powders suspected of being biological agents from nonporous surfaces.

\section{Compatibility with Biodetection Assays}

All kits use a PBS buffer for solubilizing collected samples; this buffer solution is compatible with both PCR-based detection systems and immunoassays.

\section{References}

\section{Evaluation of the Biological Sampling Kit (BiSKit) for large-area surface sampling. Appl} Environ Microbiol (2004) 70:7040-7045. This publication describes experiments performed to evaluate the BiSKit. As a result of the larger area that could be sampled with the BiSKit compared to swabs, 10 times more spores were recovered by the BiSKit ${ }^{\circledR}$ than swabs. The BiSKit ${ }^{\circledR}$ system had a sensitivity of detection of $42 \pm 5.8 \mathrm{CFU} / \mathrm{m}^{2}$ for wet sampling and $100.5 \pm 10.2 \mathrm{CFU} / \mathrm{m}^{2}$ for dry sampling and a recovery efficiency ranging from 11 to $18 \%$. 


\subsection{Non-Specific Biological Tests}

The goal of non-specific biological tests is to simply detect the presence of biological material in a sample. Typically these tests detect the presence of proteins, DNA, or ATP. Proteins and DNA are found in all cells, including spores and bacterial cells. Biological toxins, like ricin and botulinum toxin, are typically protein-based, but can be associated with DNA if the material is crudely prepared from cells. ATP is a metabolite found in living cells. Fourier Transform Infrared (FT-IR) spectroscopy is a common analytical tool that provides information about the sample properties by matching the spectral fingerprint of the sample to a library containing spectral fingerprints for thousands of compounds. Some FT-IR spectrometers include screening for biological samples, with a clear indication cautioning that the sample may be of biological origin.

While non-specific biological tests are relatively rapid and inexpensive, they should be used as a screening tool in conjunction with more specific tests. In general, these tests have low specificity and sensitivity, although the ATP test does have a reported limit of detection several orders of magnitude lower than immunoassays. These tests detect a broad range of biological materials, and therefore do not confirm the presence of a specific agent.

\section{Protein Test}

- Detects any type of protein (including milk proteins in coffee creamer and powdered infant formula)

- Protein tests may also include a pH test (biological material is typically neutral in $\mathrm{pH}$ )

- Easy to use (add sample, mix, and visually read)

- Operator manually reads color change for protein and $\mathrm{pH}$

- Sample to answer in about 5 minutes

- Detection limit: 10 to 100 million B. anthracis spores (equivalent to about 1000 to 10,000 infectious doses, but still a barely visible amount of powder, $<1 \mathrm{mg}$ )

- Typical assay cost: $\sim \$ 40$

- Typical shelf-life: 12 months

- Examples:

- Biocheck $^{\circledR}(20 / 20$ BioResponse)

- INDIPRO (Macherey-Nagel)

\section{DNA Test}

- Detects any type of DNA (e.g., human, plant, animal)

- Easy to use (add sample, mix, and read)

- Requires a fluorescence optical reader

- Sample to answer in about 5 minutes

- Detection limit: 1 to 10 billion $B$. anthracis spores (equivalent to about 1 to 10 million infectious doses and a readily visible amount of powder, approximately 1 to $10 \mathrm{mg}$ ) 
- Instrument cost (fluorometer): $\$ 12,000$

- Typical assay cost: $\$ 200$

- Typical shelf-life: 12 months

- Example: Prime Alert ${ }^{\circledR}$ (GenPrime)

\section{ATP Test}

- Tests if any cell is present and alive

- Note, for spores an additional step ( 15 minutes) must be performed prior to detection to stimulate the spore to convert to a vegetative (cellular) state to enable detection

- Requires a reader (luminometer)

- Sample to answer is about 20 minutes

- Detection limit: 10,000 B. anthracis spores (approximately one infectious dose; amount not visible by eye)

- Luminometer reader cost: $\$ 5000$

- Typical assay cost: $\sim \$ 5$

- Shelf-life: 12 months

- Example: Profile ${ }^{\circledR} 1$ (New Horizons Diagnostics)

\section{FT-IR Spectroscopy}

- These systems were initially designed to rapidly identify chemicals. Proteins (contained in most biological materials) also give a defined FT-IR spectrum and should be detected in samples containing at least $10 \%$ protein.

- FT-IR systems have not been extensively tested as a screening tool for biological material in suspicious powders. In fact, Thermo Scientific (formerly Ahura) does not recommend the use of their system for this purpose.

- Chemicals are identified by comparing their spectrum to a library containing known chemical spectra. If a chemical's spectrum is not in the library, it will remain unidentified.

- Moderate ease-of-use; mixtures can be difficult to interpret

- Sample to answer in $<5$ minutes

- Detection limit: $\sim 10 \%$ protein content in sample (No studies have been performed to determine the sensitivity in terms of number of spores).

- High instrument and upgrade costs ( $\$ 35$ to $95 \mathrm{~K})$

- No consumables

- Examples: HazMatID ${ }^{\mathrm{TM}}$ Elite and HazMatID Ranger ${ }^{\mathrm{TM}}$ (Smiths Detection); TruDefender ${ }^{\mathrm{TM}}$ (Thermo Scientific). 


\section{HazTech Systems: KT7001 HAZCAT WMD Kit}

Website: http://www.hazcat.com

Contact: Mark Parrish (mparrish@ @azcat.com)

Phone: (800) 543-5487 (ext 207)

\section{Technology Summary}

The KT7001 HAZCAT WMD Kit consists of panels of chemical and biochemical assays to identify unknown substances. The kit is specifically for WMD detection and classification and consists of two Pelican ${ }^{\mathrm{TM}}$ cases containing evidence collection tools and materials, chemical testing reagents, and biological agent testing assays. The included chemical tests can detect explosives and chemical weapons. A radiological meter capable of detecting alpha, beta, and gamma radiation is also included. The biological agent tests include separate assays for detecting amino acids/proteins: Alexeter RAID $^{\text {TM }} 8$ immunoassay tickets for detecting anthrax, plague, tularemia, brucellosis, orthopox, and botulinum, ricin, and SEB toxins; and other screens for nonbiological materials and pesticides. The kit includes materials sufficient for responding to ten incidents.

\section{Demonstrated Biodetection Assays}

The kit detects a wide variety of potential hazardous substances, including radiation, chemicals (e.g., nerve agents and pesticides), and pathogens (e.g., anthrax). The kit includes general protein and $\mathrm{pH}$ assays as well as a standalone multiplexed immunoassay for anthrax, botulinum, SEB, and ricin toxins; plague; tularemia; brucellosis; and orthopox (Alexeter RAID ${ }^{\mathrm{TM}} 8$ ).

\section{References}

No publicly available, peer-reviewed literature references were found for this product.

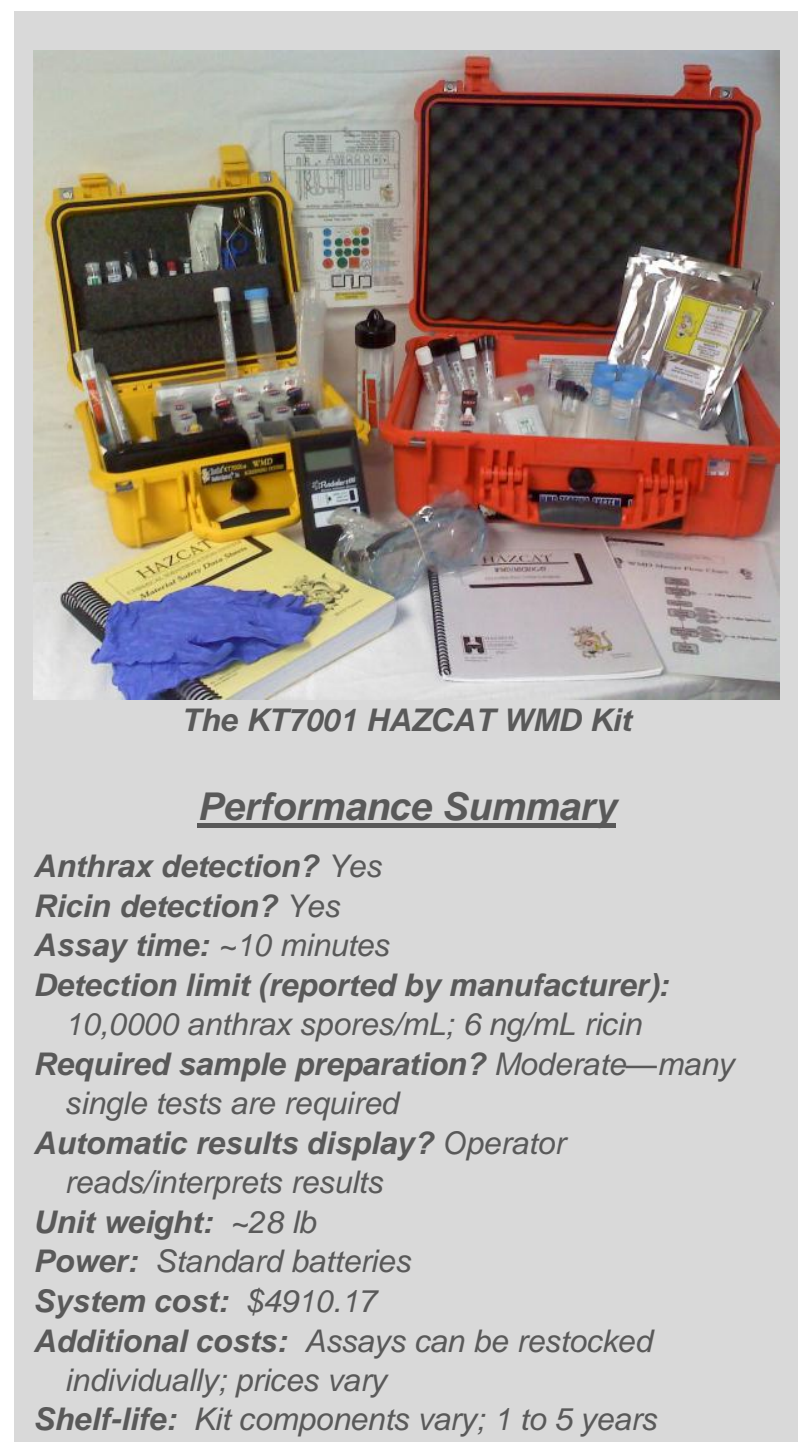




\section{GenPrime: Prime Alert ${ }^{\circledR}$}

Website: http://www.genprime.com/

Sales Contact: Ken Klein (ken.klein@ smithsdetection.com); (302) 353-0909

Technical Contact: Darby McLean (dmclean@genprime.com); (866) 624-9855

\section{Technology Summary}

The Prime Alert ${ }^{\circledR}$ System is designed to test for biological material in a white powder sample based on the presence of large amounts of DNA/ribonucleic acid (RNA) or proteinacious biothreat toxins. This sytem is distributed through Smiths Detection.

The Prime Alert ${ }^{\circledR}$ System contains two components: a microbe screen (an assay that detects DNA) and a toxin screen (lateral flow immunoassays for specific toxin detection). The advantage of the microbe screen is that it is a broad screen for any type of microbe sample, not just anthrax. However, the test is not specific and only indicates if the sample contains a large quantity of DNA. The DNA assay consists of a DNA binding dye that fluoresces only when bound to DNA. Fluroescence emission is read by a handheld fluorometer included with the system. A calibration standard is included with the kit and used to calibrate the fluroescent reader before each use. The assay takes approximately 5 minutes to run. The immunoassay toxin test is a standard lateral flow immunoassay that contains assays to detect ricin, botulinum neurotoxin serotype A, and SEB in a single cassette. The immunoassay is optimized to work with the microbe screen sample buffers, so both tests can be performed from a single solubilized sample.

\section{Demonstrated Biodetection Assays}

The Prime Alert ${ }^{\circledR}$ System microbe screen is intended to be used as a broad screen for biological material in visible powder samples.

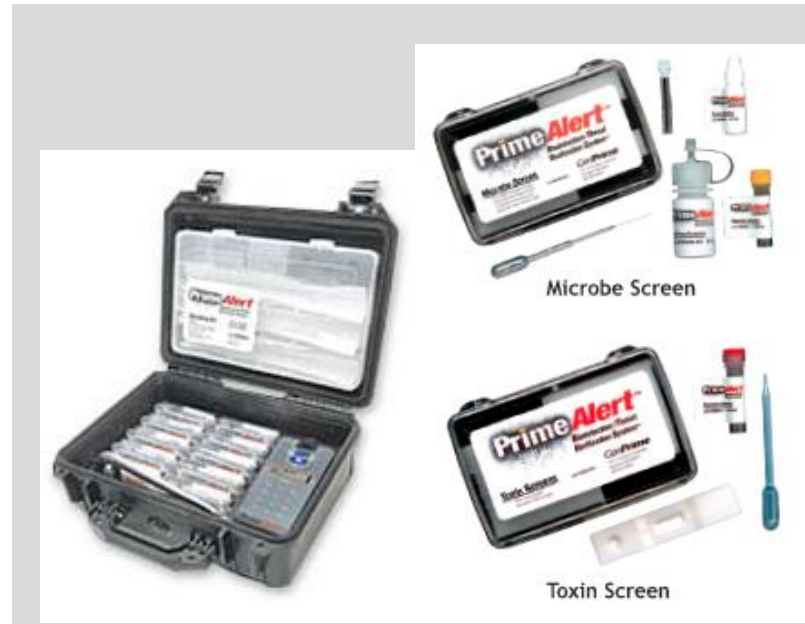

The Microbe and Toxin Screens included in the Prime Alert ${ }^{\circledR}$ System (note: the current toxin screen is a single three-agent cartridge).

\section{Performance Summary}

Anthrax detection? Yes, but not specifically, detection is based on high levels of generic DNA in sample

Ricin detection? Yes (separate immunoassay test)

Assay time: 5 minutes for microbe screen; 10 minutes for immunoassay toxin screen

Detection limit (based on published literature): microbe screen:100 million to 10 trillion spores $/ \mathrm{mL}$; immunoassay: $400 \mathrm{ng} / \mathrm{mL}$ (50 ng/test) ricin and botulinum neurotoxin

Required sample preparation? Minimal

Automatic results display? Yes, microbe test; user interprets presence/absence of a line, toxin immunoassay

Unit weight: $1 \mathrm{lb}$ (reader); $12 \mathrm{lb}$ (complete kit)

Power: 4 AAA batteries (2000+ readings)

System cost: Starter Kit: \$12,000; includes fluorometer and supplies for five complete screens and two training kits; Test Kits: $\$ 200$ (microbial and toxin screens); Microbial Screen: $\$ 90$

Additional costs: None

Shelf-life: 12 months The Prime Alert ${ }^{\circledR}$ System toxin screen is an immunoassay that detects ricin, SEB, and botulinum toxin. Testing by ECBC demonstrated that the Prime Alert ${ }^{\circledR}$ System was sensitive to 1 to 20 trillion Bacillus anthracis Sterne spores, which is significantly higher than the limit of detection reported by the manufacturer. The sensitivity was dependent on the number of times the spores were washed, as less 
washing allowed for better detection of extraneous DNA present on the surface of spores (see reference below). In contrast, an evaluation performed by Battelle in 2002 (report available upon request from GenPrime, see References) found the assay sensitive down to 100 million spores (determined using $B$. subtilis spores). This study also found that samples containing unbleached flour will give a false-positive result.

\section{References}

An evaluation of suspicious powder screening tools for first responders. J Hazard Mater. (2009) 172 (2-3), 559-65. This study reports the detection limit for anthrax spores to be between 1 to 10 trillion colony forming units (CFU) depending on how stringently the spores were washed (the more washes, the more difficult the spores were to detect). Note: the limit of detection reported by the manufacturer is between 100,000 and 1 million CFU/mg using lyophilized spores.

Final Report for Evaluation of the GenPrime Prime Alert ${ }^{\text {TM }}$ Powder Assessment Kit (Reference No. CPO50297; not peer reviewed). Prepared by Battelle Memorial Institute. (April 2002). This evaluation of the Prime Alert ${ }^{\mathrm{TM}}$ kit was sponsored by GenPrime. Document available upon request from GenPrime. 


\section{0/20: BioCheck ${ }^{\circledR}$ Powder Screening Kit}

Website: http://www.biocheckinfo.com

Contact: Barry Cohen (sales@2020gene.com)

Phone: (240) 453-6339 (ext 103)

\section{Technology Summary}

The BioCheck ${ }^{\circledR}$ Powder Screening Kit is a tool to screen for biological material in visible powder samples. Note: the test is not designed for environmental sampling (e.g., soil). A sample is collected with the provided swab for protein analysis, added to a liquid-containing tube, and allowed to incubate for 5 minutes. If the sample is positive for protein, the solution in the tube turns blue. If the protein assay is negative, the results are validated by inserting the provided control swab into the protein test tube-if the assay is working correctly, this swab should turn the solution blue. A positive protein result is a tentative indication of the presence of a biological agent or toxin. The $\mathrm{pH}$ tube determines if the sample is acidic, basic, or neutral: it will turn pink if the sample is acidic, purple if the sample is basic, and have no color change or turn slightly yellow if the sample is neutral. The $\mathrm{pH}$ of biological samples is typically neutral. Samples with an acidic $\mathrm{pH}$ may cause the protein test to fail. If a BioCheck $^{\circledR}$ test is positive, additional tests should be performed to determine the presence of a biological agent of concern or if the sample merely contains a harmless protein-containing substance (e.g., baby formula, powdered milk).

\section{Demonstrated Biodetection Assays}

The BioCheck ${ }^{\circledR}$ Powder Screening Kit has been independently evaluated using a variety of Bacillus

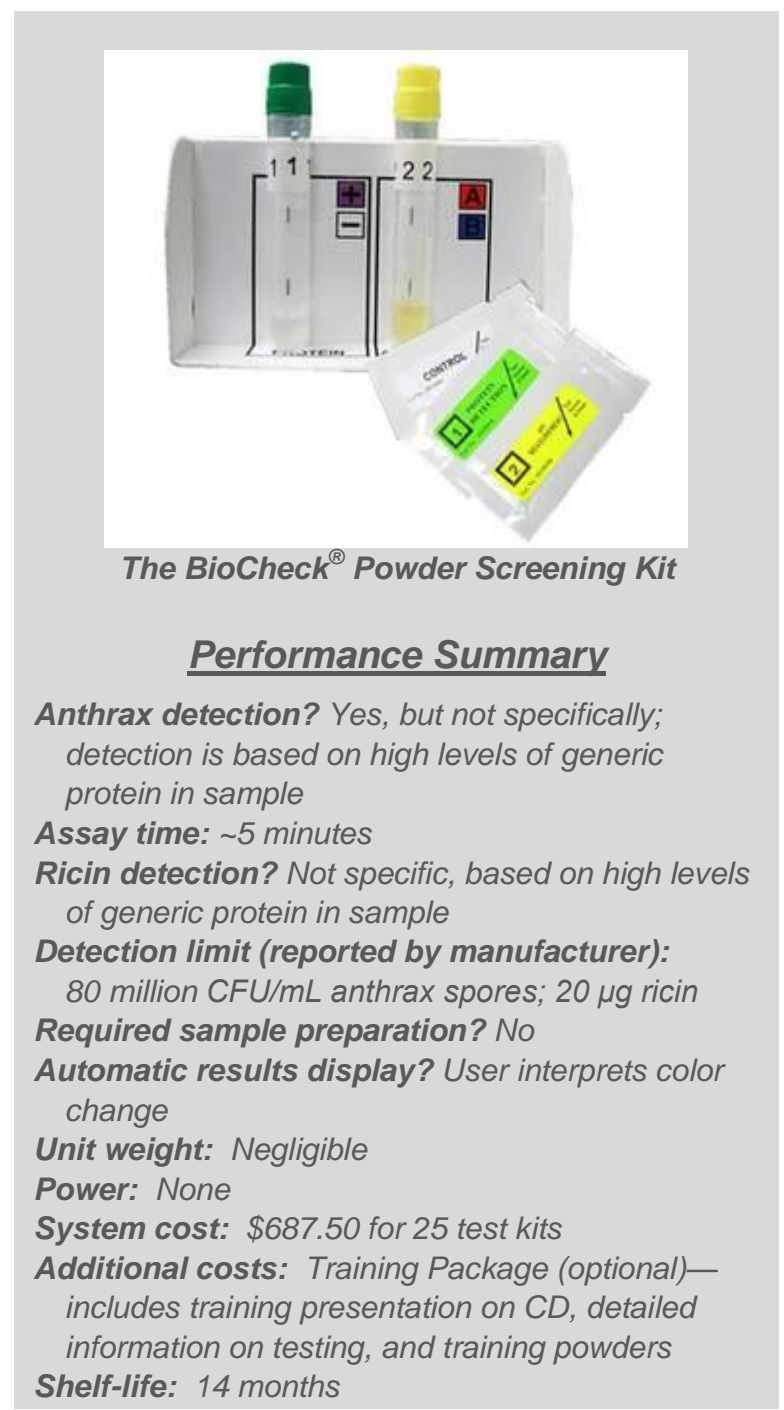

Shelf-life: 14 months species spore preparations (e.g., washed spores, unwashed spores, spores with silica). Consistent detection of protein in all samples containing $\geq 1$ million spores was reported (evaluation by Battelle, weblink to report provided in References). The BioCheck ${ }^{\circledR}$ Powder Screening Kit was also evaluated at ECBC (see reference listed below), where positive protein detection was found to depend on whether B. anthracis Sterne spores were washed or not (i.e., the method of spore preparation). In the ECBC evaluation, the average detection levels were 10 million $B$. anthracis Sterne spores and $100 \mu \mathrm{g}$ of ricin. Positive protein detection of a Yersinia pestis preparation was reported at 10 million cells. 


\section{References}

An evaluation of suspicious powder screening tools for first responders. J Hazard Mater. (2009) 172 (2-3), 559-65. This study reports the detection limit for anthrax spores to be between 10 to 100 million CFU depending on how stringently the spores were washed (the more washes, the harder the spores were to detect). Note: these studies were performed with spore samples added directly to the kit solutions, thus detection limits are not reported per milliliter. However, the reported results are within range of the detection limit reported by the manufacturer.

20/20 GeneSystems Bio-Identification Kit Testing Summary Report: Tier I and II. Prepared by Battelle. (September 2002; not peer reviewed). This evaluation of the Prime Alert ${ }^{\mathrm{TM}}$ kit was sponsored by 20/20. http://www.biocheckinfo.com/Battelle_Testing.pdf 


\section{Macherey-Nagel Indipro: Protein Test Strips}

Website: http://www.mn-net.com/tabid/10441/default.aspx

Contact: Henry Medollo (U.S. supplier at CTL Scientific Supply Group); (hmedollo@ctlscientific.com)

Phone: (631) 242-4249

\section{Technology Summary}

Like the BioCheck ${ }^{\circledR}$ Kit, these strips detect the presence of protein. The standard protocol for use is to first moisten the test strip with one drop of solution "indipro-1" and then wipe the test strip over the test surface. Next, the strip is developed by applying a drop of "indipro-2" solution directly to the strip. A color change (yellow to green) indicates the presence of protein.

\section{Demonstrated Biodetection Assays}

The indipro test is primarily marketed to the food and restaurant industries for detecting protein contamination on work surfaces and utensils. However, being an assay for generic proteins, this test can also be used in a manner similar to the $20 / 20$ BioCheck $^{\circledR}$ assay to determine if a suspicious powder contains protein. The manufacturer claims a limit of detection of $50 \mu \mathrm{g}$ protein. This detection limit was determined using a bovine serum albumin protein standard.

\section{References}

No publicly available, peer-reviewed references were found for this product.

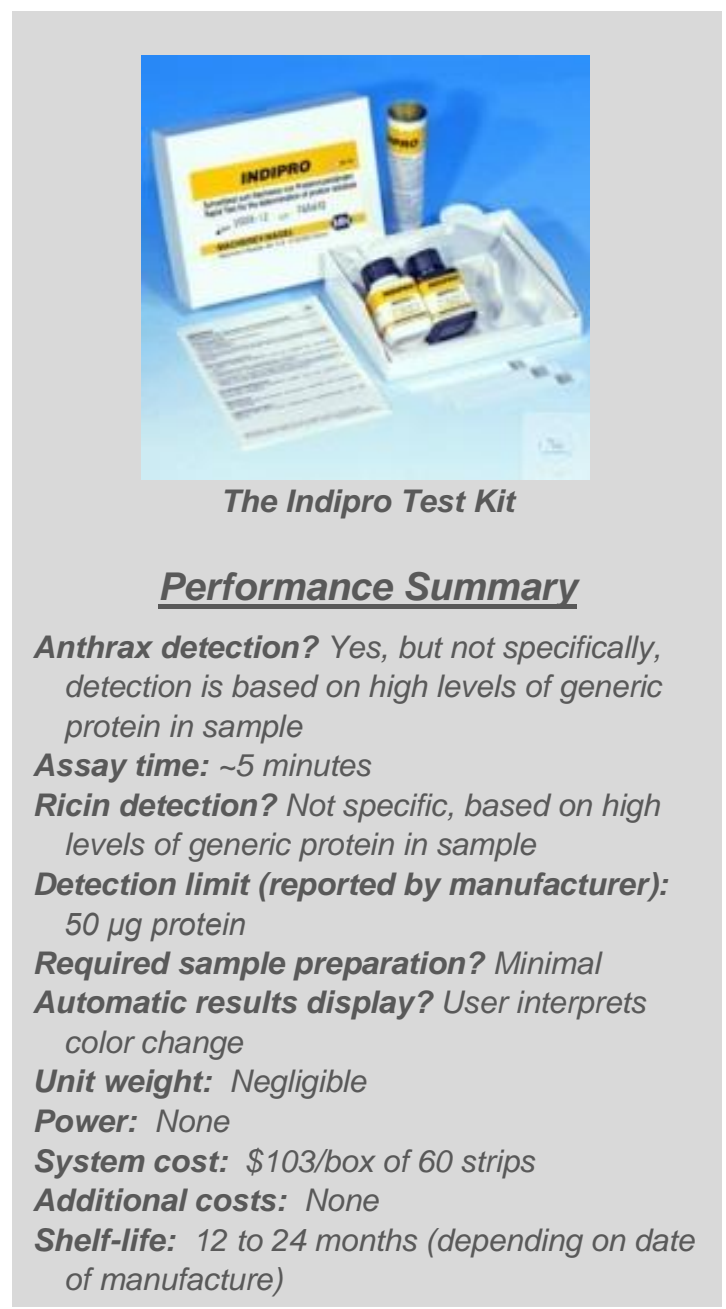




\section{New Horizons Diagnostics PROFILE ${ }^{\circledR}$ 1: ATP Test}

Website: http://www.nhdiag.com/profile_one.shtml

Contact: Larry Loomis (larryl@nhdiag.com)

Phone: (443) 543-5755

\section{Technology Summary}

The PROFILE ${ }^{\circledR} 1$ kit detects the presence of living bacterial cells by measuring the amount of ATP in a sample. ATP is a cellular metabolite present in all living cells. The amount of ATP in a sample is typically proportional to the number of living cells. The test can distinguish bacteria from human cells through the use of sample preparation methods that release ATP selectively from microbial cells. The system has two main components: a microluminometer to read ATP-induced luminescence and a "filtravette" (a filter device and cuvette combined) to concentrate cells from a sample solution and remove chemical contaminants that may interfere with the test. Samples and solutions are processed through the filtravette using an empty syringe. After the sample is processed, a solution is applied to remove non-microbial sources of ATP. Then, a microbial lysis solution is added to the filtravette, followed by a luciferase solution that produces light in the presence of ATP. After pipette mixing, the filtravette is placed in the reader and the intensity of emitted light (luminescence) is recorded. Ricin and botulinum toxin are not detected by this method.

Spores do not contain high levels of ATP and are essentially undetectable using the PROFILE ${ }^{\circledR} 1$ kit unless an incubation step is performed to initiate cell growth. When analyzing a suspected anthrax spore

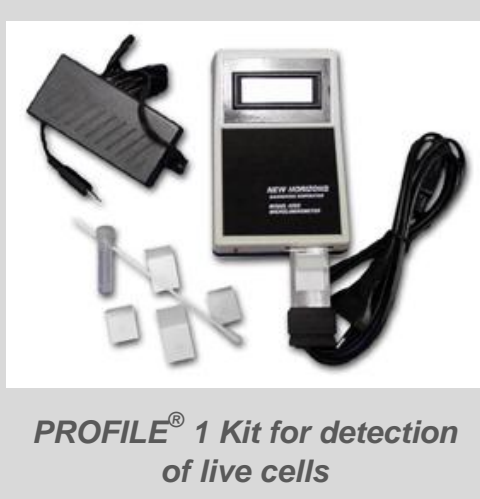

Performance Summary

Anthrax detection? Yes, but not specifically; detection is based on presence of ATP in sample Ricin detection? No

Assay time: 15 minutes (longer growth times can be used to improve sensitivity)

Detection limit (reported by manufacturer): $10,000 \mathrm{CFU} / \mathrm{mL}$

Required sample preparation? Yes

Automatic results display? User interprets numerical readout

Unit Weight: <1 lb

Power: 9V battery (1000+ reads) or AC

System cost: Profile ${ }^{\circledR} 1$ system: $\$ 5000$ (includes carrying kit, microluminometer, and pipettor), Reagent kit: $\$ 450$ (reagents and materials for 100 tests)

Additional costs: None

Shelf-life: 12 months (some reagents require refrigeration) powder, the sample must be incubated in growth media for 15 minutes and two ATP measurements taken: one prior to incubation, and one after incubation. Note: using this method, powders containing yeast cells or Dipel dust (i.e., biological insecticide) may also give a positive result.

\section{Demonstrated Biodetection Assays}

The PROFILE ${ }^{\circledR} 1$ is primarily marketed to the food safety industry as an alternative to culture methods to rapidly determine if a sample contains viable organisms. The system has been evaluated specifically for anthrax detection at ECBC (see reference below). This evaluation reported a limit of detection of 10,000 anthrax spores and notes that flour and talcum powder produce false-positive results. The manufacturer reports these false-positive reactions are eliminated by using the somatic cell releasing reagent before testing final samples in the filtravette. Since the ECBC evaluation, the manufacturer indicates that it has made improvements to the microluminometer, decreasing the detection limit 10-fold. 


\section{References}

An evaluation of suspicious powder screening tools for first responders. J Hazard Mater. (2009) 172 (2-3), 559-65. The limit of detection (LOD) reported by this study was $10,000 \mathrm{CFU} / \mathrm{mL}$, independent of the stringency of spore washing. Flour and talcum powder produced false-positive results, but may have resulted from bacterial contamination of those powders. A procedure modification made by the manufacturer may have addressed these issues. 


\section{Smiths Detection: HazMatID ${ }^{\text {TM }} \mathbf{3 6 0}$}

Website: http://www.smithsdetection.com/hazmatid360.php

Contact: Chris Lins (chris.lins@smithsdetection.com)

Phone: 770-664-8723

\section{Technology Summary}

The HazMatID ${ }^{\text {TM }} 360$ is a hand portable FT-IR spectrometer for solid and liquid samples. The device includes an integrated press to ensure high-quality data collection of solid samples and an integrated well for liquid samples. A finger or stylus can be used to control the system via a touchscreen. The software provides enhanced mixture analysis and classification tools and PEAC $^{\circledR}$ decision-support software provides detailed information regarding the management of hazardous chemicals. The system can identify over 32,000 substances, including many white powders. The system can operate in temperatures ranging from 19 to $122^{\circ} \mathrm{F}$ and in any level of humidity. A removable, rechargeable battery provides 2 hours of operation and recharges in 3 hours. The device can also use AC or automobile power. Data can be stored on removable USB, flash, floppy, or $\mathrm{CD}$ drives. The system is mouse and keyboard compatible and runs a Windows ${ }^{\circledR}$-based operating system. Available options include: ExtractIR (a system for removing chemicals from aqueous solutions for improved identification), wireless Bluetooth capability, additional spectral libraries, and a software upgrade.

\section{Demonstrated Biodetection Assays}

FT-IR is a well-established technology widely used by hazardous materials teams across the nation to identify chemical solids, liquids, and powders.

Biological materials are generically identified primarily based on protein content. Though the analysis of mixtures presents a challenge, the HazMatID ${ }^{\mathrm{TM}} 360$ alerts the user when a sample has a protein content of approximately $10 \%$ or more, indicating a sample of potential biological origin.

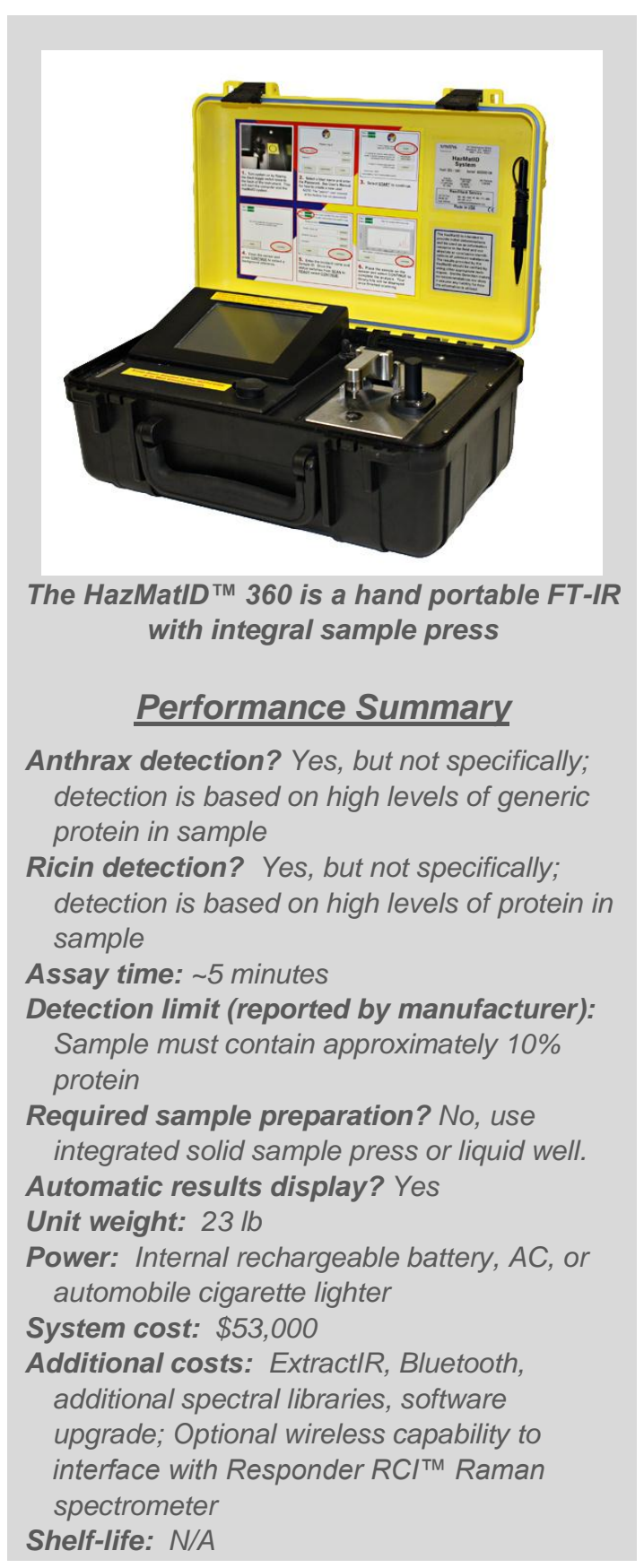

\section{References}

No publicly available, peer-reviewed references were found for this product. However, the manufacturer has published the following article in the Proceedings of the SPIE (not peer reviewed): Arno, J., et al. "Advances in Handheld FT-IR Instrumentation" Proc. SPIE 8374. http://proceedings.spiedigitallibrary.org/proceeding.aspx? articleid=1354102 


\section{Smiths Detection: HazMatID ${ }^{\mathrm{TM}}$ Ranger}

Website: http://www.smithsdetection.com/hazmatid_ranger.php

Contact: Chris Lins (chris.lins@smithsdetection.com)

Phone: 770-664-8723

\section{Technology Summary}

The HazMatID ${ }^{\text {TM }}$ Ranger is a FT-IR designed for handheld, backpack, or robot portability and ease of use. Samples are measured by firmly pressing the diamond attenuated total reflection (ATR) sensor head directly onto a liquid or solid sample. Spectral results and a list of probable substances are displayed on the attached touchscreen personal digital assistant (PDA). The ruggedized device, but not the PDA, can be decontaminated via dunking and can withstand $40 \mathrm{G}$ of shock. The instrument can operate in any level of humidity and at temperatures from 19 to $122^{\circ} \mathrm{F}$. The system battery runs for $>3$ hours and the PDA battery runs for $>8$ hours. The standard library contains spectra of $>4400$ materials, and the optional library contains spectra of $>32,000$ materials. Another additional option is wireless capability that allows communication with a laptop computer for advanced combined analysis with the Responder RCI ${ }^{\mathrm{TM}}$ portable Raman spectrometer. In addition, for difficult samples (i.e., small sample amounts or samples located on irregular surfaces), the PDA can be removed and the sample placed on an optional solids press accessory for measurement.

\section{Demonstrated Biodetection Assays}

While FT-IR is a well-established technology, use of handheld FT-IR is relatively new. Both the handheld Ranger and the hand portable HazMatID ${ }^{\mathrm{TM}} 360$ have extensive libraries used to identify materials, including most known white powders. Biological materials are identified generically, primarily based on their protein content. Though the analysis of mixtures presents a challenge, the HazMatID ${ }^{\mathrm{TM}}$ Ranger alerts the user when a sample has a protein content of approximately $10 \%$ or more, indicating a sample of potential biological origin.

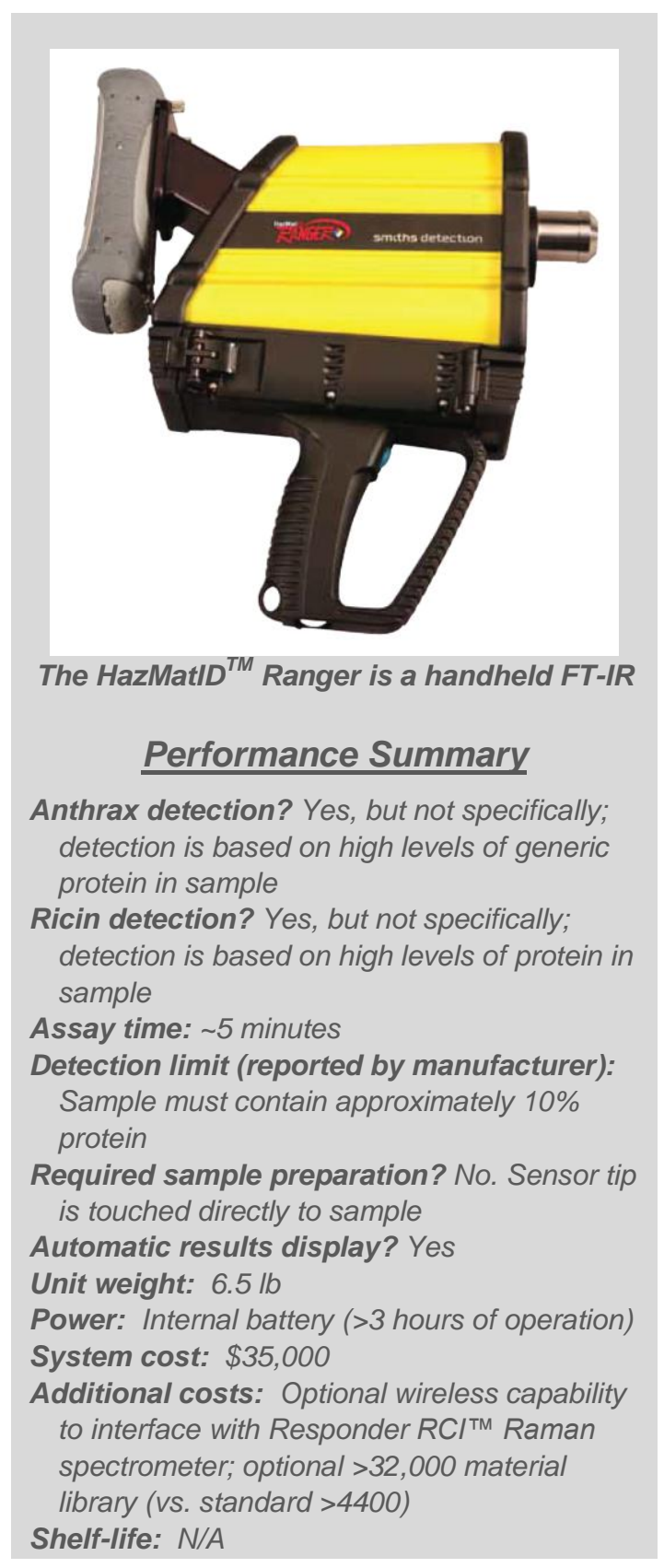

\section{References}

No publicly available, peer-reviewed references were found for this product. However, Smiths Detection offers an application brief that discusses how the HazMatID ${ }^{\mathrm{TM}}$ Ranger compares to its hand 
portable predecessor, the HazMatID ${ }^{\mathrm{TM}} 360$.

http://www.smithsdetection.com/media/Application_Brief_86_-_Handheld_FT-IR.pdf

In addition, the manufacturer has published an article in the Proceedings of the SPIE (not peer reviewed): Levy, D. "Advances in Portable FTIR Spectrometers for the field: the HazMatID Ranger" Proc. SPIE 7319. http://proceedings.spiedigitallibrary.org/proceeding. aspx?articleid=777822 


\section{Smiths Detection: HazMatID ${ }^{\mathrm{TM}}$ Elite}

Website: http://www.smithsdetection.com/HazMatIDElite.php

Contact: Chris Lins (chris.lins@ @mithsdetection.com)

Phone: 770-664-8723

\section{Technology Summary}

The HazMatID ${ }^{\mathrm{TM}}$ Elite is the next generation FT-IR specifically designed for ease-of-use in the hot zone and extreme environments. The device includes an integrated press to ensure high-quality data collection on solid samples and an integrated well for liquid samples. A second touch-to-sample diamond ATR sensor is available for analysis of pooled liquid and surface films and to enable robotics applications. The 4.3-inch color display has high visibility in direct sunlight. Easy-to-use software and on-screen instructional graphics guide the user through essential operations. Automated mixture analysis software is claimed to simplify complex sample analysis. The device is designed to military standards (MIL-STD$810 \mathrm{G}$ ) and can operate in temperatures ranging from -4 to $122^{\circ} \mathrm{F}$ and any level of humidity. A rechargeable lithiumion battery provides 4 hours of operation. The device can also use disposable 123 A batteries, as well as AC or automobile power. An embedded radio frequency (RF) modem enables line-of-sight communication of up to 1 $\mathrm{km}$ for data transfer and remote operation. A global positioning system (GPS) is also included. The device library includes 10,000 known spectra and user-defined libraries can be transferred from the HazMatID ${ }^{\text {TM }} 360$ hand portable unit. Using a command PC, an optional software package allows data management and spectral reprocessing against an upgraded library of 35,000 spectra. In addition, a RF repeater is available for extending the wireless range.

\section{Demonstrated Biodetection Assays}

While FT-IR is a well-established technology, use of handheld FT-IR is relatively new. The HazMatID ${ }^{\text {TM }}$ Elite, like the hand portable HazMatID ${ }^{\text {TM }}$ 360, has an extensive library used to identify materials including most known white powders. Biological materials are generically identified primarily based on their protein content.

Though the analysis of mixtures presents a challenge, the

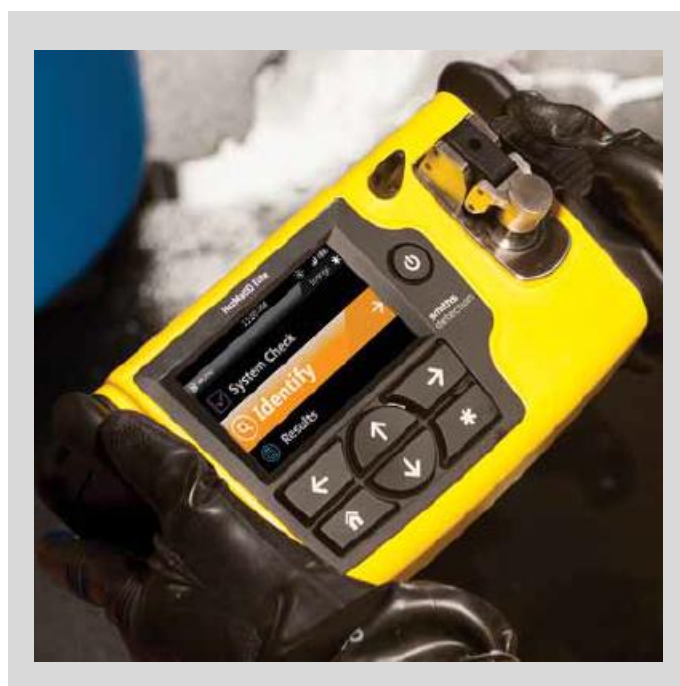

The HazMatID ${ }^{\mathrm{TM}}$ Elite is a handheld FT-IR with integral sample press

\section{Performance Summary}

Anthrax detection? Yes, but not specifically; detection is based on high levels of generic protein in sample

Ricin detection? Yes, but not specifically; detection is based on high levels of protein in sample

Assay time: $\sim 5$ minutes

Detection limit (reported by manufacturer): Sample must contain approximately $10 \%$ protein

Required sample preparation? No, touch sensor tip directly to sample or use integrated solid sample press or liquid well. Automatic results display? Yes Unit weight: $5 \mathrm{lb}$

Power: Internal rechargeable battery or disposable123A batteries (4 hours of operation)

System cost: $\$ 50,000$

Additional costs: Optional software package for data reprocessing on a remote laptop PC using 35,000 spectra library; Optional $R F$ repeater for increased wireless range Shelf-life: $N / A$ 
HazMatID ${ }^{\mathrm{TM}}$ Elite alerts the user when a sample has a protein content of approximately $10 \%$ or more, indicating a sample of potential biological origin.

\section{References}

No publicly available, peer-reviewed references were found for this product. However, the manufacturer has published the following article in the Proceedings of the SPIE (not peer reviewed): Arno, J., et al. “Advances in Handheld FT-IR Instrumentation” Proc. SPIE 8374.

http://proceedings.spiedigitallibrary.org/proceeding.aspx?articleid=1354102 


\section{Thermo Scientific (Formerly Ahura): TruDefender ${ }^{\circledR}$ FT and FTi}

Website: http://www.ahurascientific.com/chemical-explosives-id/products/trudefenderft/index.php

Contact: Tom Keller (tom.keller@thermoscientific.com)

Phone: (480) 532-6171

\section{Technology Summary}

The TruDefender ${ }^{\circledR}$ FT and FTi are handheld FT-IR instruments for analyzing and identifying chemical substances, including white powders, explosives, narcotics, and chemical weapons. The FTi version adds wireless communication, allowing results to be transmitted via email or text message. Thermo Scientific does not recommend the system for identification or detection of biological material due to the low sensitivity of FT-IR for accurately detecting biological materials in suspicious powders.

A sample is analyzed by contacting the diamond ATR sensor head directly to a liquid or solid sample. A "sample crusher," or sampling platform, is included for analyzing solid samples and volatile liquids. Once a sample is scanned, spectral results are compared to a library of known spectra. The current spectral library (version 1.5) contains over 10,000 spectra; users can also add custom spectra to the library. In addition, TruDefender ${ }^{\circledR}$ software uses an automated proprietary algorithm for analyzing mixtures of chemicals without manual spectral subtraction and subjective evaluation. The TruDefender ${ }^{\circledR}$ series is designed to be used in a hot zone wearing Level A gear. For decontamination, the unit can be immersed in water and household bleach (5\% sodium hypochlorite).

\section{Demonstrated Biodetection Assays}

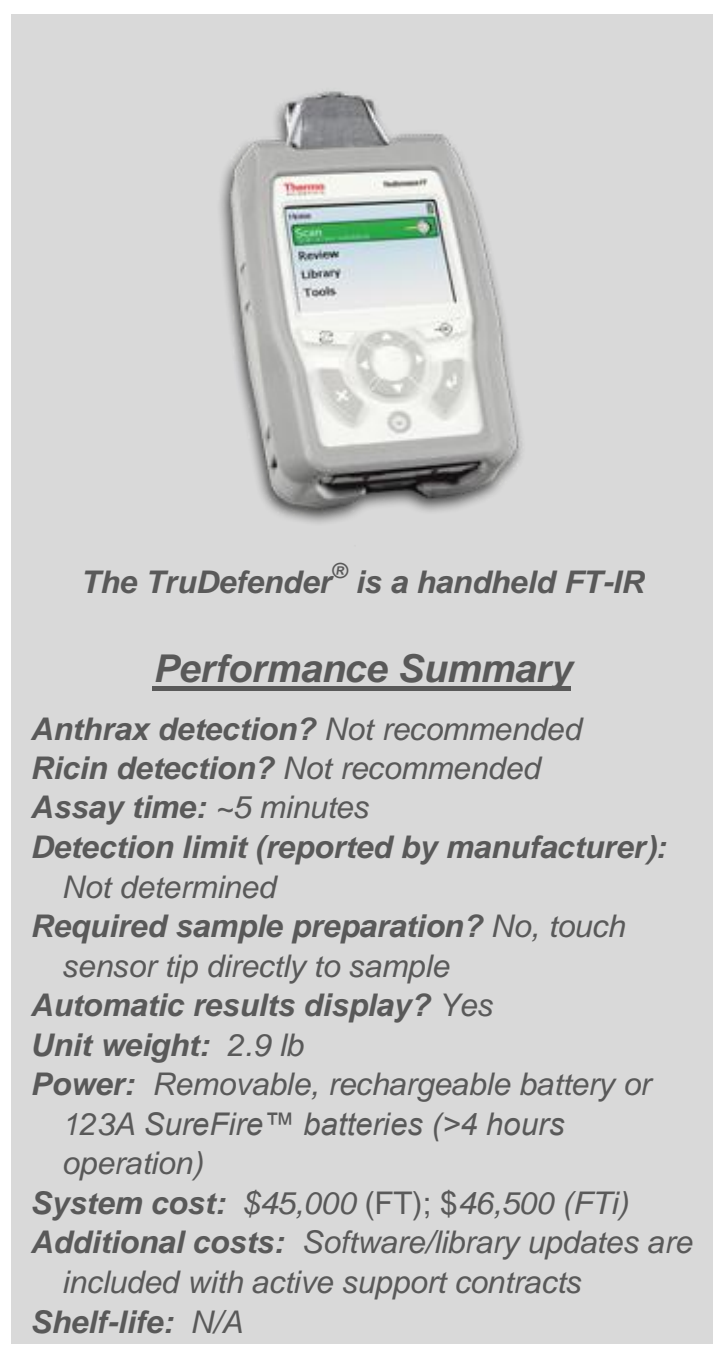

Thermo Scientific does not endorse these systems for detecting the presence of biological material in suspicious powders.

\section{References}

While several peer-reviewed publications discuss the TruDefender ${ }^{\circledR}$ system for chemical identification, no peer-reviewed publications were found for its use in detection and identification of biological materials. 


\subsection{Immunoassays}

The goal of biodetection immunoassays is to differentiate and detect the presence of specific threats (pathogen and toxin) in a sample. These assays use antibodies, which are proteins designed (by nature or in the laboratory) to bind to a specific threat agent.

Most field-based immunoassays use a lateral flow assay (LFA) format similar to a home pregnancy test. An LFA includes an assay strip containing all the assay components encased in a plastic cartridge. The cartridge has a sample window where the sample is applied to the assay strip and a results window where the results are read. LFAs require samples to be in a liquid form, which typically necessitates a swab collection kit that solubilizes material from the swab into a buffer. After a sample is collected, approximately 5 or 6 drops $(<0.5$

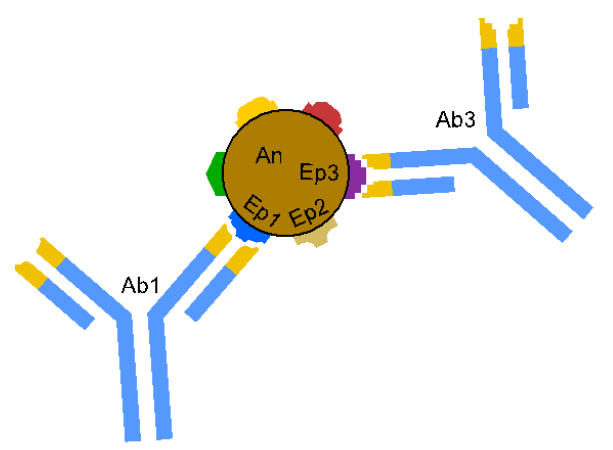

Schematic drawing of two different antibodies (Ab1 and Ab3) binding to two different regions (Ep1 and Ep3) on a target molecule. (By Antibody.svg: Fvasconcellos Epitope.png: Schorschski derivative work: Marek M (Antibody.svg Epitope.png) [CC-BY-SA-3.0], via Wikimedia Commons).

$\mathrm{mL}$ ) of sample solution are added to the sample inlet window. The sample solution is wicked across the strip and through a reagent zone that contains dye-labeled antibodies specific to the threat agent. Threat agent molecules in the sample bind to the colored antibody-dye as the sample passes through this zone. The sample continues to be wicked into a capture zone containing a second set of antibodies that bind the threat agent/antibody-dye complex. The secondary antibodies in the capture zone are immobilized in a line across the strip so that, as capture proceeds, a visible line (the test line) develops in the test window. Adjacent to the capture zone is a control zone that contains immobilized antibodies (the control line) that bind to the antibody-dye directly. For an assay to be considered positive, both the test and control lines must be visible. For an assay to be considered negative, only the control line should be visible.

Immunoassays are advantageous because they are relatively inexpensive, require little skill to use, and results can be obtained in only 5 to 15 minutes. However, the specificity and sensitivity of immunoassays vary depending primarily on the quality of the antibodies used in the assay. For example, some antibodies can bind very low concentrations of target threat agent resulting in a very sensitive assay. Other antibodies may bind the target molecule but also have some affinity for closely related molecules (like non-pathogenic relatives of B. anthracis that are found naturally in the environment). Furthermore, immunoassays are subject to false negatives resulting from interferents and highly concentrated samples. For example, if there are more target molecules than dye-labeled antibody molecules, unlabeled target molecules may bind to the test line and effectively block the labeled target molecules from binding. In this situation, the target line would be negative and the control line may or may not be positive (depending on the assay design). Typical detection limits for immunoassays range from 100,000 to 10 million spores or microbes.

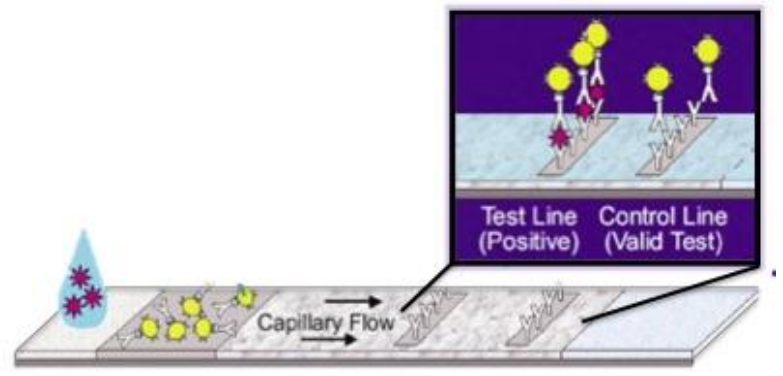

IIlustration of a Typical Immunoassay. (By U.S. National Aeronautics and Space Administration (Lateral_Flow_Assay.jpg) [Public domain], via Wikimedia Commons) 


\section{Single Target Tests}

- Assay cost: $\sim \$ 25$ to 30

- Reader cost: $\$ 5$ to $10 \mathrm{~K}$ (optional)

- Note: the reader improves sensitivity and accuracy and may help to identify a hook effect (excess target threat agent) condition

- Examples: BADD ${ }^{\mathrm{TM}}$ (Advnt), BioDetect ${ }^{\mathrm{TM}}$ (Alexeter), and many others

\section{Multiple Target Tests}

- 3- to 8-plex ticket

- Assay cost: $\$ 70$ to 100

- Optional reader for NIDS ${ }^{\mathrm{TM}}$ : $\$ 7.5 \mathrm{~K}$

- Examples: Pro Strips ${ }^{\mathrm{TM}}$ (Advnt), RAID ${ }^{\mathrm{TM}}$ (Alexeter), NIDS ${ }^{\mathrm{TM}}$ (Smiths Detection) and others

\section{Automated Systems}

- BIOSENSOR ${ }^{\text {TM } 2200 R}$ (MSA/QTL)

- 2-plex (Bacillus spores, ricin toxin)

- Detection limit $\sim 10,000$ Bacillus spores

- Assay cost: $\$ 50$

- Instrument cost: \$16K

- RAPTOR ${ }^{\mathrm{TM}}$ (Research International)

- 4-plex

- Assay cost: $\$ 200$

- Instrument cost: $\$ 49.5 \mathrm{~K}$ 


\section{Advnt: BADD ${ }^{\mathrm{TM}}$ Biowarfare Agent Detection Devices}

Website: http://www.advnt.org/

Contact: Kevin Borah (kevinb@advnt.org)

Phone: (888) 223-3269

\section{Technology Summary}

The Advnt Biowarfare Agent Detection Devices $\left(\mathrm{BADD}^{\mathrm{TM}}\right.$ ) are LFAs for the detection of specific biothreats. These devices test for one agent/target at a time. Each test comes with an all-in-one swab kit that contains a swab, sample buffer, and pipette/dropper tube. Following sampling, the test is initiated by adding five or six drops $(\sim 0.2 \mathrm{~mL})$ of sample to the sample inlet window. Results (presence/absence of lines in the test window) can be seen in 15 minutes; however, with concentrated samples a positive result may be obvious after only three minutes. The test produces one of three results: positive - target detected (two lines in the test window, one for the target and one for the internal positive control), negative - target not detected (single line at the positive control zone), and inconclusiveassay error (no lines, or a single line for the target but no control line).

\section{Demonstrated Biodetection Assays}

Individual tests are available for anthrax, plague, ricin, botulinum, and SEB. Advnt reports that the LOD of the anthrax assay ranges from 15,000 to 83,000 spores $/ \mathrm{mL}$ depending on the strain tested. This equates to approximately 3000 to 16,600 spores if a five to six drop ( $\sim 0.2 \mathrm{~mL}$, according to the manufacturer) sample is applied. The LODs reported by the manufacturer for other biothreat targets are: $10 \mathrm{ng} / \mathrm{mL}$ for ricin, 33 $\mathrm{ng} / \mathrm{mL}$ for botulinum $\mathrm{A}, 500 \mathrm{ng} / \mathrm{mL}$ for botulinum $\mathrm{B}$, 100,000 organisms $/ \mathrm{mL}$ for $Y$. pestis, $10 \mathrm{ng} / \mathrm{mL}$ for SEB, and 1.4 million CFU/mL for $F$. tularensis. Peerreviewed studies (listed in the references) in 2003 and 2007 report higher detection limits; however, the manufacturer indicates these studies were performed

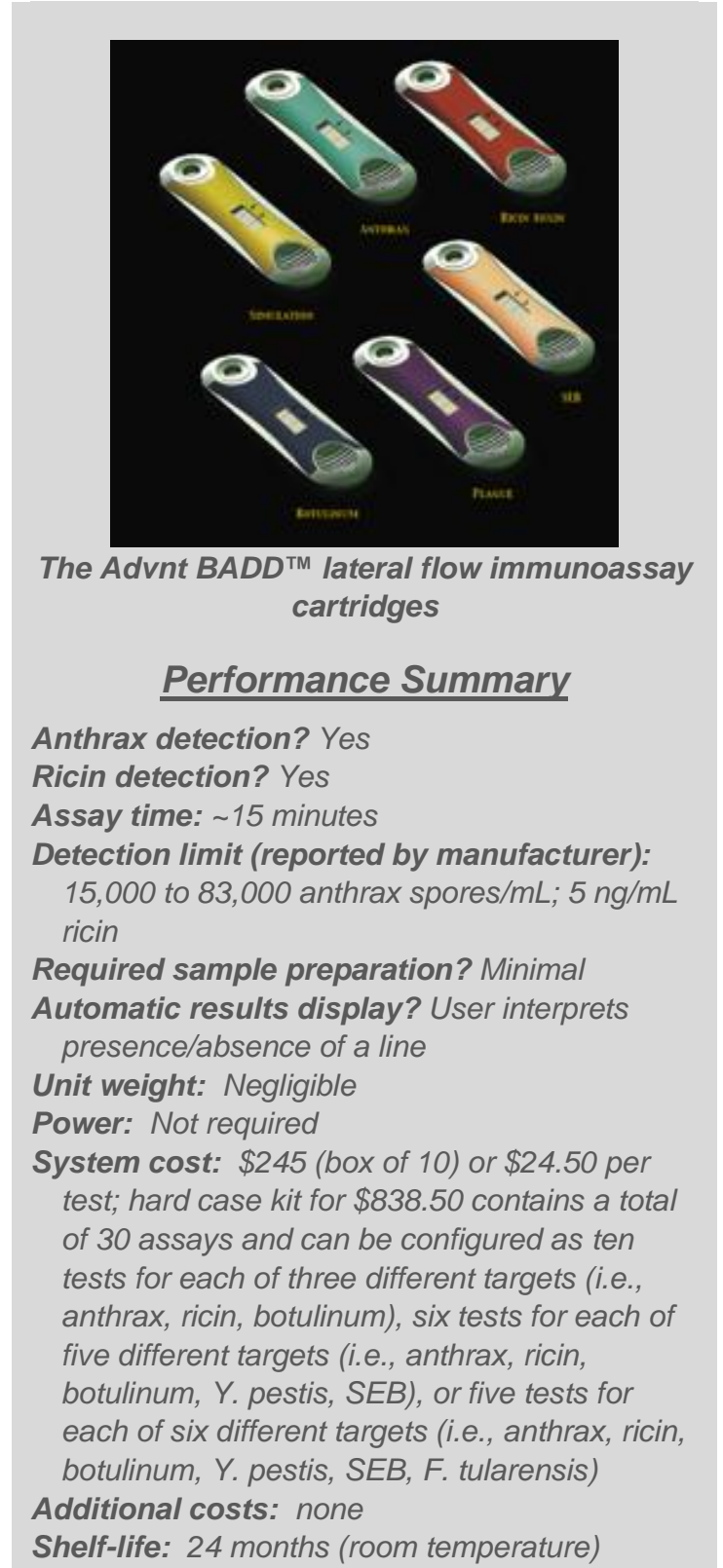
with the first generation of the assay, which has been subsequently updated several times $(2006,2010$, 2012/2013). A weblink to Advnt-sponsored performance specifications is provided in the References.

\section{References}

Performance Assessment of Three Commercial Assays for Direct Detection of B. anthracis Spores. Journal of Clinical Microbiology (2003) 3454-3455. This brief study evaluated the $1^{\text {st }}$ generation 
$\mathrm{BADD}^{\mathrm{TM}}$ anthrax assay ( $4^{\text {th }}$ generation assay is expected to be released in 2013) and reported detection of 100,000 spores in three out of three tests; the assay could not detect 10,000 or less spores. The volume of the sample applied was not reported.

Evaluation of lateral flow assays for the detection of botulinum neurotoxin type $A$ and their application in laboratory diagnosis of botulism. Diagnostic Microbiology and Infectious Disease (2007) 57 243-249. This study reports the detection limit of the $1^{\text {st }}$ generation assay for botulinum neurotoxin type A to be $100 \mathrm{ng} / \mathrm{mL}$ using a $125 \mu \mathrm{L}$ sample (currently Advnt recommends using a $0.2 \mathrm{~mL}$ sample (5 to 6 drops)). This study also found the assay detects both purified toxin and toxin in complex with its natural, non-toxic carrier proteins.

Performance Spec Sheets for Prostrips and BADD. Results reported by Advnt. (2012) http://www.advnt.org/products/biowarfare/techlibrary/SpecSheet_PS_and_BADD.pdf 


\section{Advnt: Pro Strips ${ }^{\mathrm{TM}}$ Multi-Agent Detection Tests}

Website: http://www.advnt.org/

Contact: Kevin Borah (kevinb@advnt.org)

Phone: (888) 223-3269

\section{Technology Summary}

The Advnt Pro Strips ${ }^{\mathrm{TM}}$ are basically the BADD ${ }^{\mathrm{TM}}$ assays bundled into a single cartridge. In the Pro Strips ${ }^{\mathrm{TM}}$ assay, one sample is automatically divided among five different tests (i.e., anthrax, ricin, botulinum, $Y$. pestis, and SEB). Following sample collection with the included all-in-one swab kit, approximately 10 to 11 drops $(\sim 0.4 \mathrm{~mL})$ of the solution is added to the sample inlet window. Results are read in a separate window for each target tested. For a valid test, a control line must also be observed in each window. The recommended incubation time is 15 minutes, but results may be generated in as little as 3 minutes for concentrated samples.

\section{Demonstrated Biodetection Assays}

The Pro Strips ${ }^{\mathrm{TM}}$ cartridge contains assays for 5 targets: B. anthracis, ricin, SEB, botulinum toxin, and $Y$. pestis. The manufacturer asserts that because the assays are essentially the same as the BADD ${ }^{\mathrm{TM}}$ individual assays, they will have the same LODs and are reported as: 15,000 to 83,000 spores/mL (assuming a $0.4 \mathrm{~mL}$ sample is applied to cartridge this equates to 6000 to 33,200 spores), $10 \mathrm{ng} / \mathrm{mL}$ for ricin, $33 \mathrm{ng} / \mathrm{mL}$

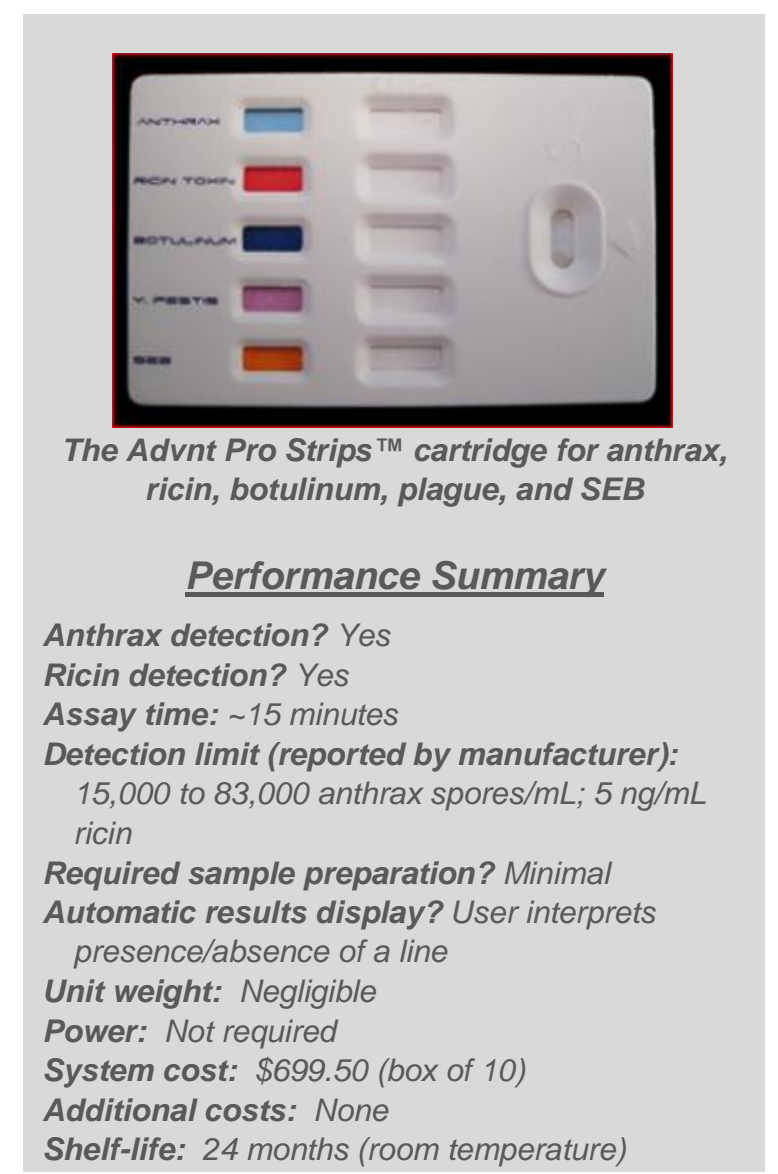
for botulinum neurotoxin serotype A, 100,000 CFU/mL for $Y$. pestis, and $10 \mathrm{ng} / \mathrm{mL}$ for SEB. A weblink to Advnt-sponsored performance specification studies is provided in References.

\section{References}

No publicly available, peer-reviewed literature references were found for this product.

Performance Spec Sheets for Prostrips and BADD. Results reported by Advnt. (2012) http://www.advnt.org/products/biowarfare/techlibrary/SpecSheet_PS_and_BADD.pdf 


\section{Alexeter: BioDetect ${ }^{\mathrm{TM}}$ Test Strips}

Website: http://www.alexeter.com/biow/index.asp

Contact: Tom Fryzel (tfryzel@alexeter.com)

Phone: (877) 591-5571

\section{Technology Summary}

The Alexeter BioDetect ${ }^{\mathrm{TM}}$ Test Strips are standard single target/agent LFAs. Prior to 2005, Alexeter BioDetect ${ }^{\mathrm{TM}}$ strips were manufactured by Tetracore and identical to the BioThreat Alert ${ }^{\circledR}$ Test Strips. However, the current product is independent of Tetracore and includes different reagents. Each cartridge comes with a sampling kit that includes an integrated swab, buffer, and dispenser. To initiate the assay, a 3 to 5 drop sample $(\sim 150$ to $250 \mu \mathrm{L})$ is dispensed into the sample window. After a 15-minute incubation, the test can be read either by eye or with the Alexeter Guardian ${ }^{\mathrm{TM}}$ Reader or Defender ${ }^{\text {TM }}$ TSR (Test Strip Reader). There are two test lines in the test window: a control line in which a red line should always develop for a valid test and a sample line in which a red line appears if the target is detected. For a valid result, positive or negative, the control line must always be visible. For the toxin assays, the manufacturer recommends running an additional test with a 1:40 dilution of the sample to minimize the possibility of oversampling (hook effect).

For increased accuracy and sensitivity, these test strips can be read with the Alexeter Guardian ${ }^{\mathrm{TM}}$ Reader or Defender ${ }^{\mathrm{TM}}$ TSR systems (available separately). The primary advantages of using either reader are an objective interpretation of the test result and enhanced detection sensitivity (reported by the vendor as approximately 10 -fold. The Guardian ${ }^{\mathrm{TM}}$ Reader is approximately the size of a toaster, and the Defender ${ }^{\mathrm{TM}}$ TSR is handheld.

\section{Demonstrated Biodetection Assays}

Test strips are available for anthrax, ricin, and botulinum toxins; plague; brucellosis; and pox. Alexeter reports the LOD for anthrax spores to be 1 to 5 million $\mathrm{CFU} / \mathrm{mL}$ or $\sim 225,000$ to 1.1 million spores applied to the test strip (assuming a $3 \mathrm{drop} / 150 \mu \mathrm{L}$ sample). A weblink to Alexeter-reported performance specifications is provided in References. A previous evaluation performed by the U.S. EPA Technology Verification (ETV) Program in 2004 does not apply to the current version of

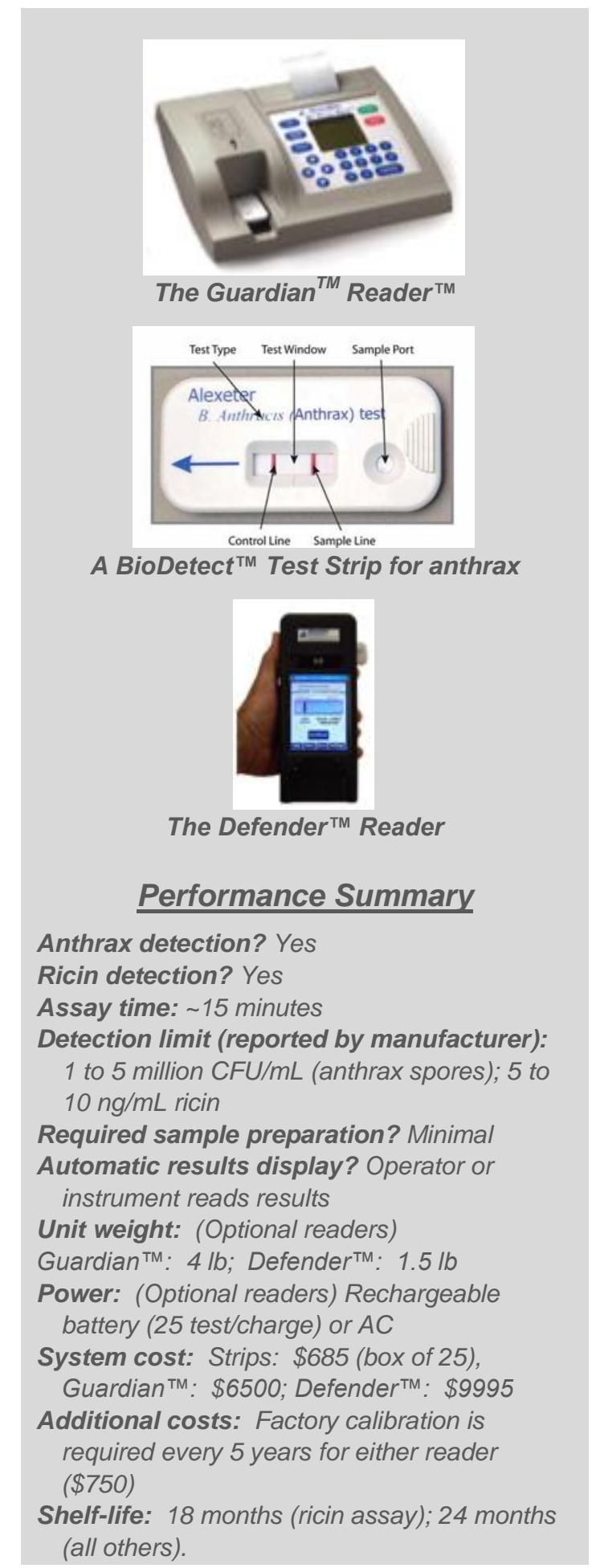


the test strips, which include different reagents.

\section{References}

No publicly available, peer-reviewed references were found for this product.

Alexeter Anthrax (B. anthracis) Bio-Detect Test ${ }^{\mathrm{TM}}$ Specifications. Summary provided by Alexeter. http://www.alexeter.com/biow/products/products/strips/spec\%20sheets/Anthrax\%20Test\%20Strip\%20Sp ecifications\%20Bio-Detect\%20_1p_.pdf 


\section{Alexeter: RAID ${ }^{\mathrm{TM}}$ Multi-Test Strips}

Website: http://www.alexeter.com/biow/index.asp

Contact: Tom Fryzel (tfryzel@alexeter.com)

Phone: (877) 591-5571

\section{Technology Summary}

Alexeter RAID ${ }^{\mathrm{TM}} 5$ and RAID ${ }^{\mathrm{TM}} 8$ are multiplex LFA strips, which can test simultaneously for five and eight different targets, respectively, from a single sample. Each cartridge comes with a sampling kit that includes an integrated swab, buffer, and dropper dispenser. In the RAID tests, 6 drops of sample $(\sim 300 \mu \mathrm{L})$ are applied to each sample window (RAID ${ }^{\text {TM }} 5$ has a single window; RAID $^{\text {TM }} 8$ has two windows). These multiplexed cartridges work on the same principle as the single target BioDetect ${ }^{\mathrm{TM}}$ test strips: if a biothreat is present, a colorimetric reaction occurs and a line appears in the " $\mathrm{T}$ " zone of the results window. For valid results, a line must be observed in the " $\mathrm{C}$ " zone (internal positive control) of the results window. These assays are not compatible with the Alexeter Defender ${ }^{\mathrm{TM}}$ TSR or Guardian ${ }^{\mathrm{TM}}$ Reader.

\section{Demonstrated Biodetection Assays}

The RAID ${ }^{\mathrm{TM}} 5$ has assays for B. anthracis, Y. pestis, and botulinum, ricin, and SEB. The RAID ${ }^{\mathrm{TM}} 8$ adds three additional assays: Brucella, orthopox, and Francisella. Alexeter reports the following detection limits: anthrax $100,000 \mathrm{CFU} / \mathrm{ml}$ (this equates to approximately 30,000 spores, assuming a $300 \mu \mathrm{L}$ sample is applied), botulinum toxin $30 \mathrm{ng} / \mathrm{ml}$, brucellosis 1.5 million CFU/ml, orthopox 1.6 million PFU $/ \mathrm{ml}$, plague 36,000 CFU $/ \mathrm{ml}$, ricin $6 \mathrm{ng} / \mathrm{ml}$, SEB $10 \mathrm{ng} / \mathrm{ml}$, and tularemia 1.6 million CFU/ml. A summary of performance specifications can be requested from Alexeter (see References for details).

\section{References}

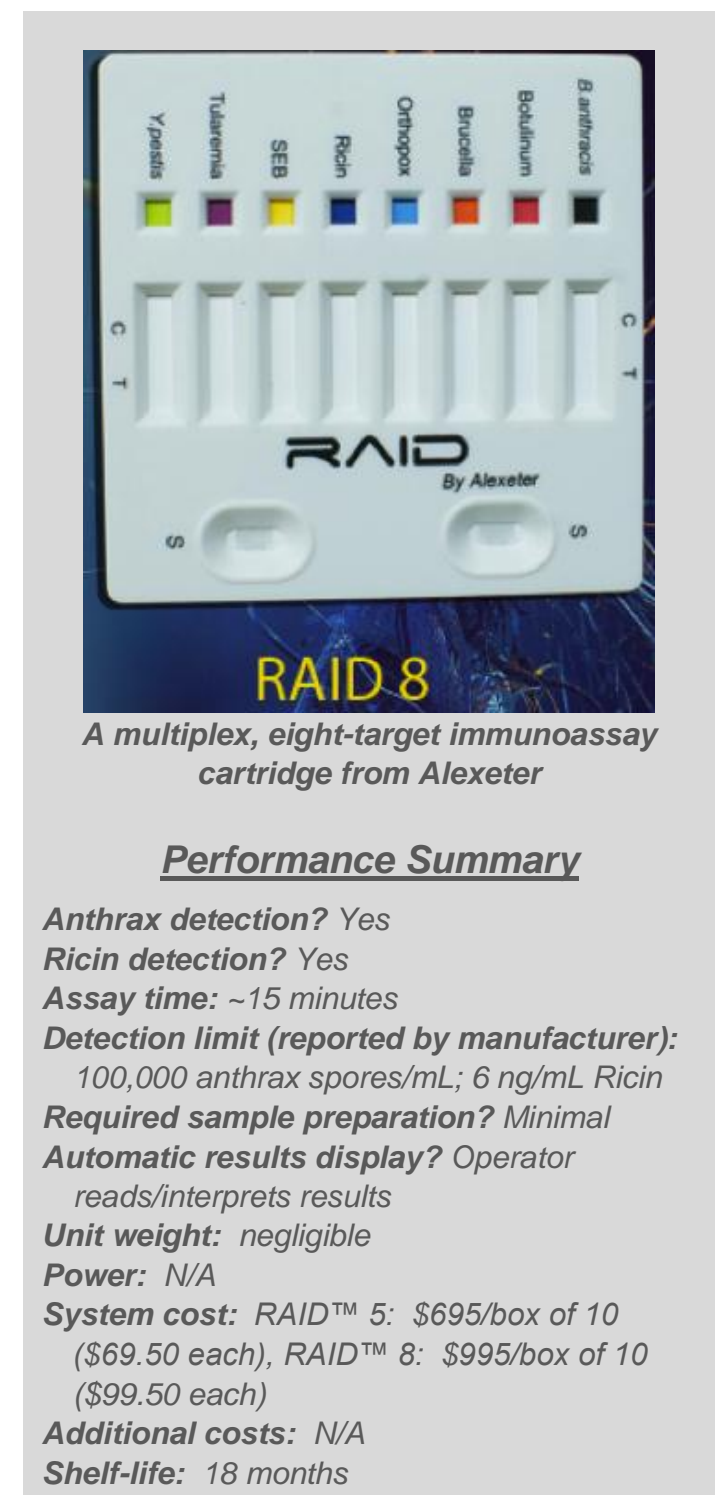

No publicly available, peer-reviewed references were found for this product.

Alexeter RAID 8 BioThreat Detection Kit ${ }^{\mathrm{TM}}$ Specifications. Summary of performance specifications available by request from Alexeter. 


\section{Environics: ENVI Assay System}

Website: www.environicsusa.com

Contact: Chris Wrenn (sales@environicsusa.com)

Phone: (410) 612-1250

\section{Technology Summary}

Environics markets the ENVI assay, a colorimetric LFA. The ENVI assay can be read by eye or with a reader. The Environics Reader Module is designed to be an add-on module for the ChemPro100 Chemical Detector, but also can be used alone, connected to a laptop computer. The reader can be powered by a USB port or directly from the ChemPro100 Chemical Detector. Colorimetric ENVI assays are available for SEB, ricin, and botulinum toxins. Each assay includes all materials required for analysis (e.g., sampling swabs, buffers, transfer pipettes) packaged in a box that doubles as a sample-preparation platform.

\section{Demonstrated Biodetection Assays}

Colorimetric ENVI assays are available for the detection of ricin, SEB, and botulinum toxin with reported sensitivities of ricin $5 \mathrm{ng} / \mathrm{mL}$, SEB $13.1 \mathrm{ng} / \mathrm{mL}$, and botulinum toxin $10 \mathrm{ng} / \mathrm{mL}$.

\section{References}

No publicly available, peer-reviewed references were found for this product; however, test reports may be requested from the vendor.

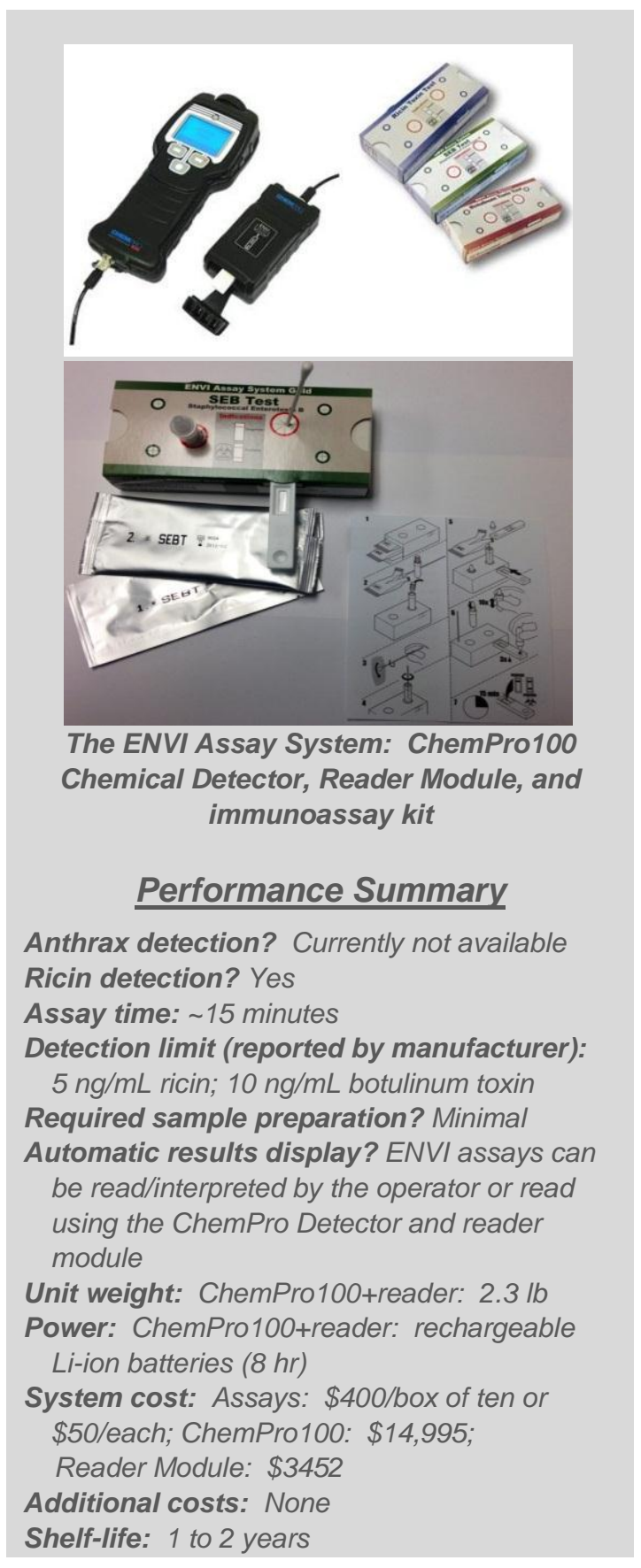




\section{MSA/QTL: BIOSENSOR ${ }^{\text {TM }}$ 2200R}

Website: http://www.msafire.com/ (sales and info) or http://www.qtlbio.com (info)

Contact: Norm Davis (Norm.Davis@MSAnet.com) or Brian Oswalt (boswalt@qtlbio.com)

Phone: (724) 776-8884 (MSA) or (724) 575-0033 (QTL)

\section{Technology Summary}

The BIOSENSOR ${ }^{\mathrm{TM}}$ 2200R (developed by QTL Biosystems and sold in the United States by MSA) is a fluorescence-based immunoassay developed for downrange biothreat detection. A red light/green light (threat present/absent) result is delivered in 5 minutes. The assay protocols are set up for powder samples, but wet samples may also be evaluated. Each disposable assay cartridge kit comes with a sample collection swab, a sample vial, and syringes for sample and wash buffer delivery into the cartridge. Once a sample and wash buffer are injected into the cartridge, the user shakes the cartridge manually for 1 minute to dissolve the sensing materials (i.e., a pair of antibodies that both bind to the target) - one has a fluorescence label for detection the other has a magnetic bead attached for immobilization on the sensor. A complex is formed between the antibodies and target biothreat molecules in solution, and then a magnetic field is applied to concentrate the magnetic beads and complexes into a pellet on the sensing surface. After the pellet is formed, the operator is prompted to depress the wash syringe plunger to remove any potentially interfering materials before the fluorescence is read. Protocols for sample processing are laminated inside the lid of the Pelican ${ }^{\mathrm{TM}}$ case where the unit is housed and the instrument prompts the operator at each step in the process. To verify a positive result, the sample must also be analyzed using a negative control cartridge. Likewise, to verify a negative result, a positive control cartridge must also be analyzed. MSA has a comprehensive training video on YouTube (BIOSENSOR ${ }^{\mathrm{TM}}$ 2200R.mp4) that demonstrates the process with an operator wearing Level A protection.

An updated version of this system, the BIOSENSOR 4000 , is in development by QTL. This system automates the mixing and washing processes, which improves the ease-of-use, precision, and sensitivity of the system, and updates the optics, allowing additional multiplexing capabilities. The manufacturer estimates that the BIOSENSOR 4000 system will be priced below $\$ 20,000$.

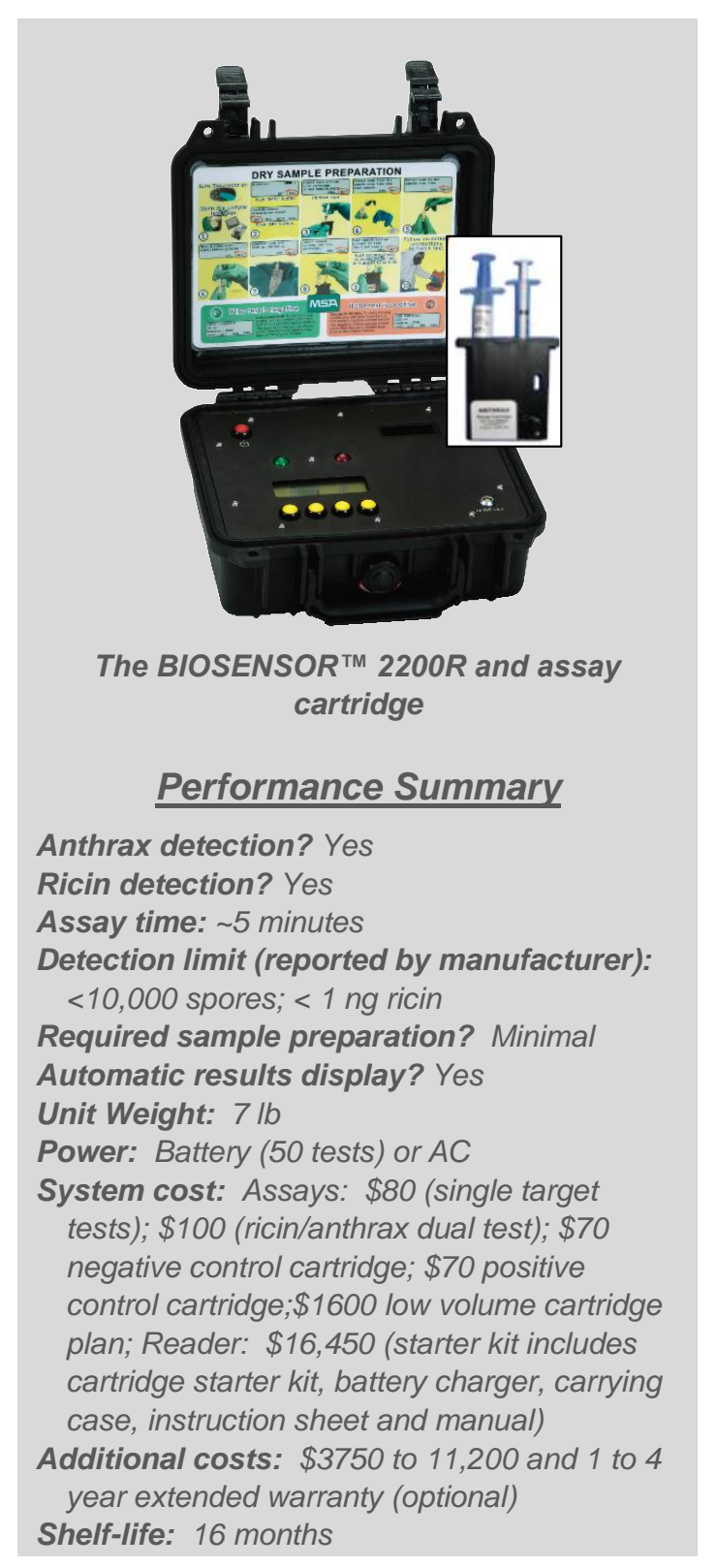

Anthrax detection? Yes Ricin detection? Yes

Assay time: 5 minutes

Detection limit (reported by manufacturer): $<10,000$ spores; $<1$ ng ricin Unit Weight: $7 \mathrm{lb}$

Power: Battery (50 tests) or AC tests); $\$ 100$ (ricin/anthrax dual test); $\$ 70$ negative control cartridge; $\$ 70$ positive control cartridge; $\$ 1600$ low volume cartridge plan; Reader: \$16,450 (starter kit includes cartridge starter kit, battery charger, carrying case, instruction sheet and manual) Additional costs: $\$ 3750$ to 11,200 and 1 to 4 year extended warranty (optional) Shelf-life: 16 months 


\section{Demonstrated Biodetection Assays}

Assay cartridges are available for anthrax and ricin (both as single tests and a duplex). Third-party testing of the anthrax assay, conducted by the University of Alabama (UAB) and the New York State Department of Health (Wadsworth Center), found the LOD to be between 5000 (NYDOH) and 12,000 (UAB) spores depending on the strain and spore preparation method. Weblinks to test reports are provided in References. In 2006, the EPA ETV program evaluated the Biosensor ${ }^{\mathrm{TM}} 2200 \mathrm{R}$ and reported the LOD for anthrax spores to be between 100,000 and 500,000 spores $/ \mathrm{mL}$ and ricin to be between 0.05 and $0.25 \mathrm{mg} / \mathrm{L}$ (weblink to report provided in References). In both assays, interference was observed in samples containing magnesium and calcium; however, the manufacturer reports the buffer has been reformulated since this testing and the assay is no longer affected by these metal ions.

In addition, MSA sells cartridge quantities in plans designed for low ( 1 call/2 months), medium ( 2 calls/month), and high volume ( 5 calls/month) usage. As an example, the low volume plan includes: six anthrax/ricin dual kits, two anthrax and two ricin single kits, six positive control cartridges, two negative control cartridges, two calibration kits, and two wet sample kits. Although a calibration kit is available, MSA/QTL maintains it is not necessary and the instrument light sources (LEDs) are stable for 100,000 hours of use.

\section{References}

No independently published, peer-reviewed publications were found.

Performance Verification of the QTL Biosensor at the University of Alabama (UAB). Summary of performance testing performed at the University of Alabama. Test performed in September-November, 2004. Study (not peer reviewed) was sponsored by QTL Biosystems. http://s7d9.scene7.com/is/content/minesafetyappliances/BIOSENSOR\%202200R\%20UAB\%20Report\%2 $0-\% 20 \mathrm{EN}$

Evaluation Report on the QTL Biosystems Bacillus anthracis Cartridges and $\beta$-unit Reader. Summary of performance testing performed at the Biodefense Laboratory, Wadsworth Center, NY State Department of Health. Study (not peer reviewed) was sponsored by QTL Biosystems. http://s7d9.scene7.com/is/content/minesafetyappliances/BIOSENSOR\%202200R\%20NYDOH\%20Repor $\mathrm{t} \% 20-\% 20 \mathrm{EN}$

Environmental Technology Verification (ETV) Report for QTL Biosystems, LLC: QTL Biosensor for Detecting Anthrax and Ricin. Testing performed by Battelle between November 2005 and March 2006. http://www.epa.gov/etv/pubs/600etv06093.pdf 


\section{New Horizons Diagnostics: Smart ${ }^{\mathrm{TM}}-$ II}

Website: http://www.nhdiag.com/profile_one.shtml

Contact: Larry Loomis (larryl@nhdiag.com)

Phone: (443) 543-5755

\section{Technology Summary}

The New Horizons Diagnostics (NHD) Smart ${ }^{\mathrm{TM}}$-II is a standard LFA. Each device tests for one agent/target at a time. One kit contains the LFA device, plastic droppers, and Chase buffer. A separate collection kit (either an NHD kit or another validated collection system) must be purchased separately. If the sample contains visible debris or large particles, a sample-processing kit should be used (also sold by NHD) prior to loading sample on to the LFA. The test is initiated by adding three drops $(\sim 100 \mu \mathrm{L})$ of liquid sample to the sample well on the device using the provided dropper. After waiting three minutes for the sample to absorb in the sample well, two drops of Chase buffer is added from the Chase buffer dropper bottle. After a 15-minute incubation, the results can be read. The test produces one of three results: positive - target detected (two lines in the test window, one for the target and one for the internal positive control), negative - target not detected (single line at the positive control zone), and inconclusive - assay error (no lines, or a single line for the target but no control line).

\section{Demonstrated Biodetection Assays}

NHD reports the sensitivity for anthrax spores to be $100,000 \mathrm{CFU} / \mathrm{mL}$ which translates to 10,000 spores assuming a 3 drop/100 $\mu \mathrm{L}$ sample applied to the device. An independent evaluation sponsored by NHD and performed by the Pacific Northwest National Laboratory (PNNL) supports these findings (report provided upon request from NHD, see References).

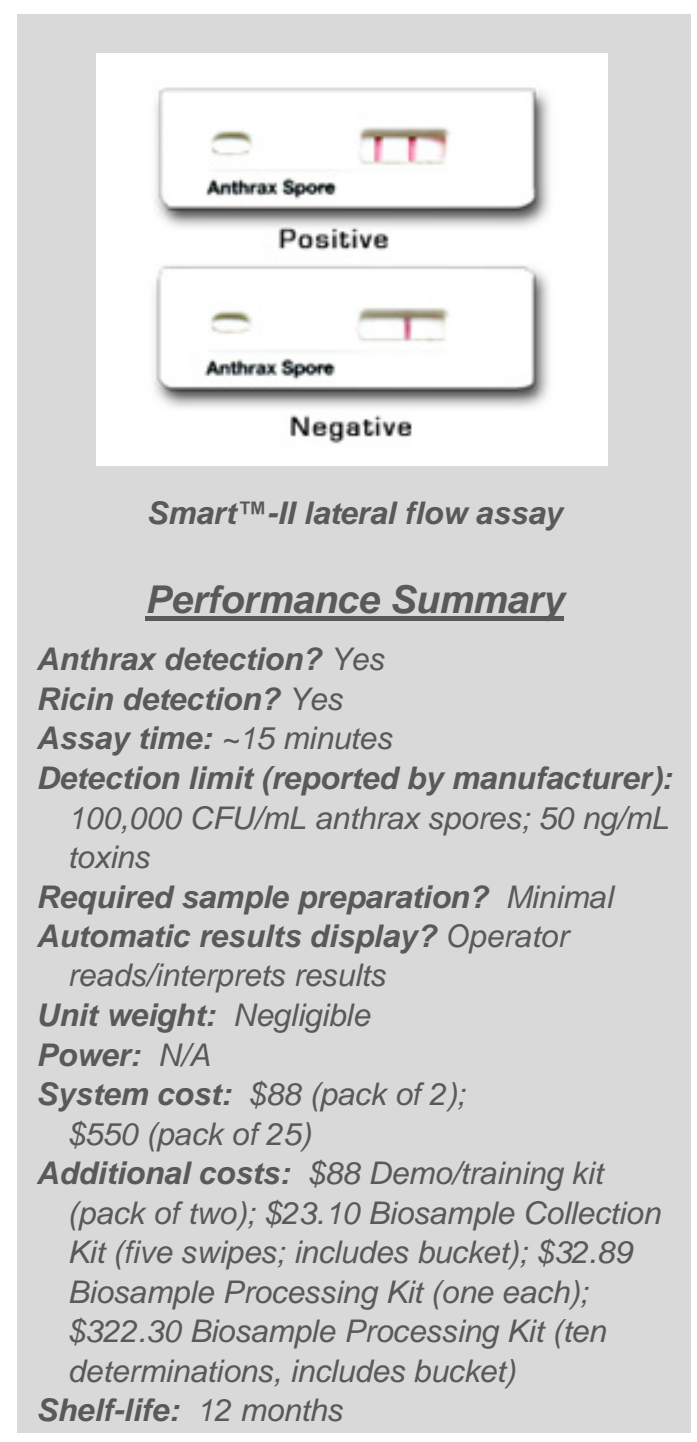

\section{References}

Performance Assessment of Three Commercial Assays for Direct Detection of B. anthracis Spores. Journal of Clinical Microbiology (2003) 3454-3455. This brief study performed by the Florida Department of Health Laboratory, reports detection of 100,000 spores per sample. The volume of the sample applied was not reported.

Task 14: B. anthracis lateral flow devices validation. Technical report of PNNL-RCMDT Contract \#325786-A-K6. Reporting period: 01.04.05-30.06.05. Report of third-party testing results (not peer reviewed); available upon request from NHD. 


\section{Response Biomedical: RAMP ${ }^{\circledR}$}

Website: www.responsebio.com

Contact: Lindsey Cowan (customersupport@ responsebio.com)

Phone: (604) 456-6010 (ext 6076)

\section{Technology Summary}

The RAMP ${ }^{\circledR}$ system is a fluorescence-based lateral flow immunoassay system. The assay uses a fluorescence-based detection scheme that requires an optical reader. The complete RAMP ${ }^{\circledR}$ Biodefense System provides all the materials required to run an assay including sampling swabs, buffers, fluorescence reader, and printer in a waterproof Pelican ${ }^{\mathrm{TM}}$ case. Four assay kits (anthrax, ricin, botulinum neurotoxin, and smallpox) are provided with the system in addition to a Biodefense Training Kit that is supplied at the free-of-charge onsite training by Emery \& Associates. Response Biomedical also provides comprehensive training tutorials for the system on its website. Sample preparation for this assay is slightly more involved than a standard colorimetric LFA; however, the assay is more sensitive than standard LFAs. Initial swab sampling follows standard methods (swab and solubilize in sample buffer). However, transferring the sample to the assay cartridge involves first mixing with the dyelabeled detection antibody, which is dried in the transfer pipette tip. The operator must slowly depress and release the plunger ten times and check that the sample is fully mixed by confirming that the pink dot is no longer visible on the inside of the tip. Once the sample is mixed, the assay proceeds

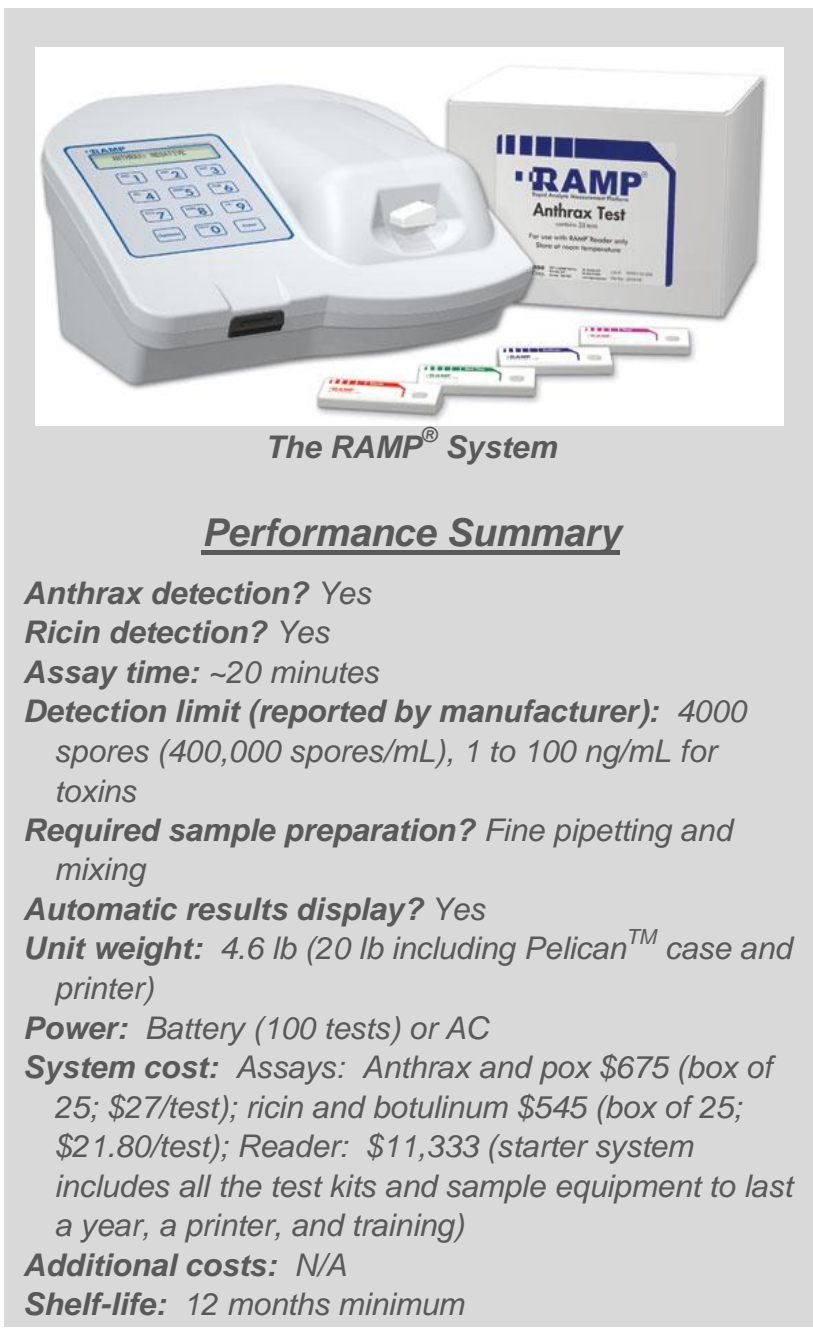

like a typical LFA (add sample to sample window, insert in to the fluorescence reader, and incubate for 15 minutes). Unlike standard LFAs, the positive control that is incorporated into the proprietary RAMP Ratio $^{\circledR}$ corrects for variability in operator technique, sample volume, environmental conditions, and sample viscosity.

As with standard LFAs, RAMP ${ }^{\circledR}$ has an internal positive control, which is automatically read by the system and used for signal processing and quality control when analyzing and displaying the results.

\section{Demonstrated Biodetection Assays}

Response Biomedical has assays available for the detection of anthrax, ricin, botulinum neurotoxin, and smallpox. The anthrax assay is currently the only commercial handheld immunoassay that has a 
"Performance Tested Status" issued from the AOAC Research Institute. The initial performance evaluation was performed in 2004, and the assay has been recertified annually since then as "performing to the manufacturer's specifications." In addition, the system was evaluated at ECBC and was found to specifically detect between 1000 and 2000 anthrax spores (weblink to study report provided in References). However, the EPA ETV 2004 evaluation found the assay to be less sensitive, detecting between 7 to 8 million anthrax spores (700 to 800 million spores $/ \mathrm{mL}$ ) depending on spore preparation (weblink to report provided in References). The EPA evaluation did find the assay to be very sensitive to vegetative Bacillus anthracis cells (3000 cells or 300,000 CFU/mL).

\section{References}

RAMP $^{\circledR}$ anthrax test cartridge. Journal of AOAC International (2005) 88(1):202-3. This article summarizes the protocol for using the $\mathrm{RAMP}^{\circledR}$ assay for presumptive laboratory detection of $B$. anthracis spores in environmental samples. No test data are reported.

Method modification (2004.08) to field-testing of visible powders on a variety of nonporous environmental surfaces: field study. Journal of AOAC International (2006) 89(6):1622-8. This paper provides a summary of RAMP ${ }^{\circledR}$ anthrax assay field-testing performed by trained first responders and civil support teams in Class $\mathrm{C}$ personal protective equipment. Test accuracy was at least $97 \%$ for all surfaces tested.

Evaluation of the rapid analyte measurement platform (RAMP ${ }^{\circledR}$ ) for the detection of Bacillus anthracis at a crime scene. Forensic Science International (2007) 171(1):1-4. This study looked at the accuracy and reliability of the RAMP ${ }^{\circledR}$ system for anthrax detection. It found the LOD to be 6200 spores $(10 \mu \mathrm{L}$ sample with a concentration of $620,000 \mathrm{CFU} / \mathrm{mL})$ and no cross-reactivity with closely related near neighbor spores (Bacillus thuringiensis and Bacillus cereus tested at 100 million spores per $10 \mu \mathrm{L}$ sample) and no interference observed with samples containing common household powders.

Evaluation of lateral flow assays for the detection of botulinum neurotoxin type $A$ and their application in laboratory diagnosis of botulism. Diagnostic Microbiology and Infectious Disease (2007) 57: 243-249. This study reports the detection limit for botulinum neurotoxin type A to be $50 \mathrm{ng} / \mathrm{mL}$ using a $10 \mu \mathrm{L}$ sample diluted into the sample buffer as directed. This study also found the assay detects both purified toxin and toxin in complex with its natural, non-toxic carrier proteins.

Evaluation of a Rapid Immunoassay System for the Detection of Bacillus anthracis Spores. Report (not peer reviewed) prepared by US Army Edgewood Chemical and Biological Center, Aberdeen Proving Ground, MD. http://www.accutest.net/products/pdf/EdgewoodEvaluation.pdf

Environmental Technology Verification (ETV) Report for Response Biomedical Corp., RAMP Test Cartridges for detecting anthrax, botulinum toxin, and ricin. Testing performed by Battelle between January 14 and April 23, 2004. http://www.epa.gov/etv/pubs/01_vr_ramp.pdf 


\section{Research International: RAPTOR ${ }^{\mathrm{TM}}$}

Website: http://www.resrchintl.com

Contact: David McCrae (davidmccrae@ resrchintl.com)

Phone: (360) 805-4930/(703) 625-8381

\section{Technology Summary}

The RAPTOR ${ }^{\mathrm{TM}}$ is a portable assay system first introduced in 2000. It can be configured to detect a wide range of analytes including biological agents, toxins, explosives, and chemicals using antibody-based assays. The RAPTOR ${ }^{\mathrm{TM}}$ is essentially a fluorescence reader with integrated fluidics, electronics, and software, which reads proprietary disposable optical waveguide sensors. The system is highly configurable - the user can define multi-step assay protocols and develop their own assays and assay coupons. There are also a range of pre-defined assays and coupons for biothreat targets.

The disposable assay coupons are about the size of a credit card and contain four reaction surfaces (channels containing sensor elements/waveguides) that can be used to simultaneously detect four different target biothreats. The assay coupons can be functionalized by the user, or purchased preconfigured. The pre-configured assay coupons contain a barcode that is automatically read by the instrument and sets up the run parameters for the assay. The system delivers the sample to the

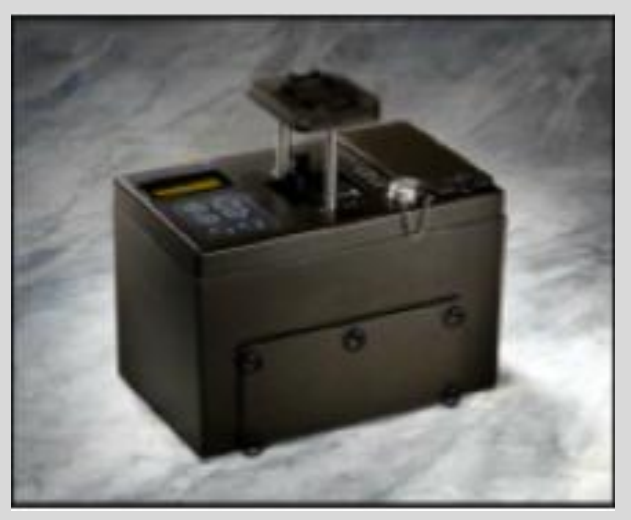

The RAPTOR ${ }^{\mathrm{TM}}$ System

\section{Performance Summary}

Anthrax detection? Yes

Ricin detection? Yes

Assay time: $\sim 15$ minutes

Detection limit (reported by manufacturer):

10,000 spores $/ \mathrm{mL}, 1$ to $100 \mathrm{ng} / \mathrm{mL}$ for toxins

Required sample preparation? Reconstitute detection antibody dried in vial

Automatic results display? Yes

Unit weight: $12.3 \mathrm{lb}, 14.5 \mathrm{lb}$ with battery

Power: Optional military battery BA5590 (9 to 24

hours); rechargeable is also available

System cost: Assays: $\$ 200$; Reader module: $\$ 50,000$ Additional costs: None

Shelf-life: 6 months reaction surface, which has an immobilized antibody that captures the target on the surface. Then the system can be configured for a wash step (to remove unbound material) before a second fluorescently labeled antibody specific for the target is automatically delivered to the surface. To run an assay, the user adds buffer to the detection antibody (supplied dried in a vial), connects the vial to the system, adds $1 \mathrm{~mL}$ of liquid sample to the coupon, inserts the coupon into the reader, and presses the "Run Assay" key. For all assays, the first run performed daily must be a 'blank' assay to set the baseline. Each assay including the initial blank run, takes approximately 10 to 15 minutes to complete. If an assay is negative, the coupon can be re-used in an 8 to 12 hour period for up to 30 assays or until a positive result is obtained.

\section{Demonstrated Biodetection Assays}

The system is currently used in various settings, including corporate mailrooms and food processing facilities. Assays are available for anthrax, ricin, botulinum toxin, Y. pestis, Francisella tularensis, and Vaccinia virus. Additional assays are available including cocaine and trinitrotoluene (TNT) (explosive). Reported assay sensitivities have been gathered from various third-party research groups and are not guaranteed by Research International. The following LODs have been reported: irradiated anthrax spores 
$(50,000$ spores $/ \mathrm{mL}$ or 50,000 spores in a $1 \mathrm{~mL}$ sample), ricin $(1 \mathrm{ng} / \mathrm{mL})$, and botulinum neurotoxin (1 to $10 \mathrm{ng} / \mathrm{mL})$.

\section{References}

RAPTOR ${ }^{\text {TM: }}$ a fluoroimmunoassay-based fiber optic sensor for detection of biological threats. Sensors Journal, IEEE (2003) 3(4):352-360. This research paper summarizes the RAPTOR ${ }^{\text {TM }}$ design (e.g., optics, fluidics). This paper includes data for research and development assays (not commercial) for detecting SEB and anthrax spores. 


\section{Smiths Detection: NIDS ${ }^{\mathrm{TM}}$ (Developed by ANP Technologies)}

Website: http://www.smithsdetection.com

Contact: Ken Klein (ken.klein@ @ smithsdetection.com)

Phone: (302) 353-0909

\section{Technology Summary}

Nano Intelligent Detection System (NIDSTM) consists of LFA strips and an optical reader for detection. NIDSTM is a standalone component of the Smiths Bio Triage $\mathrm{Kit}^{\mathrm{TM}}$ that integrates NIDS ${ }^{\mathrm{TM}}$ with simple protein/pH tests $\left(\right.$ BioCheck $^{\circledR}$ 20/20), FT-IR characterization (HazMatID ${ }^{\text {TM }} 360$ ), and a DNA test (Prime Alert ${ }^{\mathrm{TM}}$ ) for a complete tiered approach using orthogonal assays for evaluating suspicious powders.

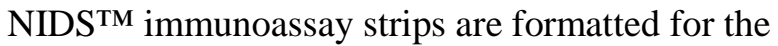
detection of three, four, or five targets in a single cartridge. The manufacturer claims that its proprietary method of immobilizing the capture antibodies in a uniform orientation on the test strips decreases the likelihood of hook effect artifacts that produce false negative results when very concentrated samples are analyzed.

Each test comes with a sampling kit containing transfer dropper bottles, buffer solution, powder scoops, swabs, and sample collection vials. Operation is quite simple, with the user placing $100 \mu \mathrm{L}$ (about 5 drops) of the sample solution in the sample well of the test strip. The test strip is then allowed to develop for 15 minutes and placed into the palm-sized reader for detection. The results are displayed on the screen.

\section{Demonstrated Biodetection Assays}

Multiplexed test strips are available that analyze a single sample for three, four, or five targets simultaneously. Commercial assays are available for the

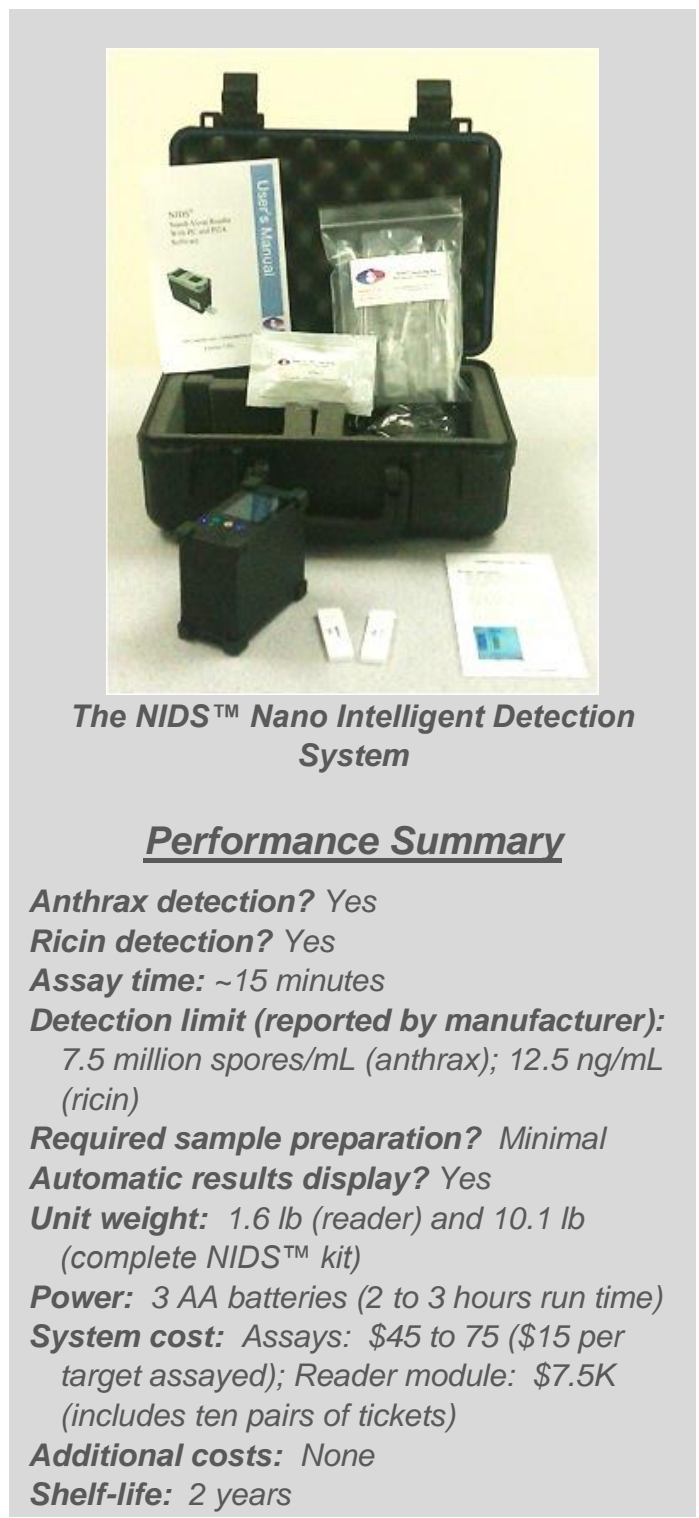
following biothreat targets: anthrax, ricin, plague, botulinum toxin (serotypes A and B), tularemia, smallpox, and SEB. Reported sensitivity for anthrax spores is $7.5 \mathrm{million} / \mathrm{mL}$ (or 750,000 spores assuming a $0.1 \mathrm{~mL}$ sample is applied to device).

\section{References}

No publicly available, peer-reviewed references were found for this product. 


\section{Tetracore: BioThreat Alert ${ }^{\circledR}$ Test Strips and Reader}

Website: http://www.tetracore.com/bio-warfare/

Contact: Pete Pillay (ppillay@tetracore.com)

Phone: (260) 268-5400

\section{Technology Summary}

Tetracore BioThreat Alert ${ }^{\circledR}$ Test Strips are standard single target/agent LFAs. Each BioThreat Alert ${ }^{\circledR}$ kit (containing 25 strips) comes with 5 sample collection swabs and vials. Additional sample collection kits can be purchased separately. Once a sample is collected and solubilized, the user applies 5 drops $(\sim 150 \mu \mathrm{L})$ of sample to the test strip sample window. After a 15-minute incubation period, the results can be read by eye in the test window: one line at the control zone indicates the target was not detected, two lines (one control and one test) indicate the target was detected.

For increased accuracy and sensitivity, an optional reader is available. The reader is essentially a tablet-sized, handheld, touchscreen device that provides an objective interpretation of the test results. Following the test incubation period, it takes approximately 30 seconds for the reader to analyze a strip and give an output of positive, negative, or inconclusive. The reader saves and prints the test results, and also includes an attached optional stylus.

\section{Demonstrated Biodetection Assays}

Test strips are available for anthrax, abrin, ricin, botulinum toxin, plague, brucella, SEB, tularemia, and orthopox. Tetracore reports the anthrax test to have a sensitivity of 10,000 to 1 million CFU/mL (1500 to 150,000 spores, assuming a $0.15 \mathrm{~mL}$

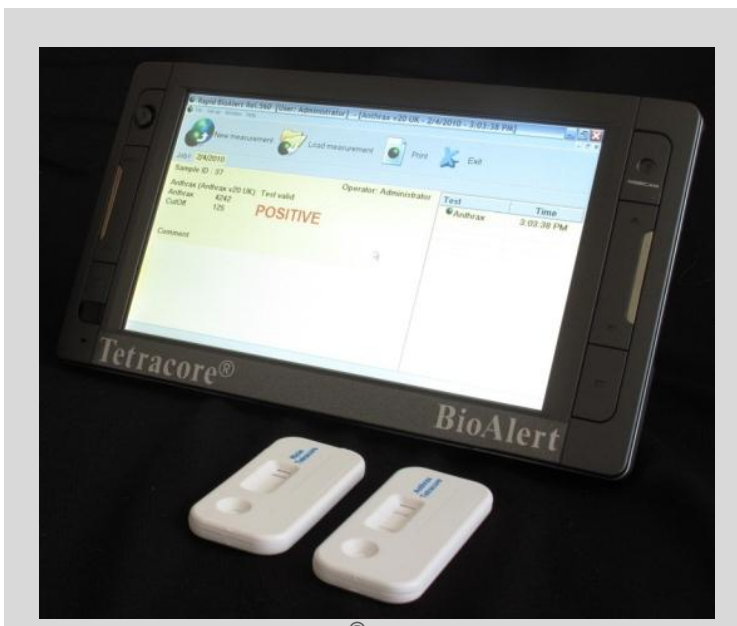

The BioThreat Alert ${ }^{(\Theta)}$ Reader and Test Strips

\section{Performance Summary}

Anthrax detection? Yes

Ricin detection? Yes

Assay time: 15 minutes

Detection limit (reported by manufacturer): Anthrax: 10,000 to 1 million CFU/mL; ricin: 2 to $5 \mathrm{ng} / \mathrm{mL}$ Ricin

Required sample preparation? Minimal

Automatic results display? Automated reader or user observes lines

Unit weight: Reader: $2.1 \mathrm{lb}$

Power: Not required; optional reader has rechargeable battery (5 hours)

System cost: Assays: \$605/box of 25

(\$24.40/assay); Sample Collection Kit: \$125 (25 sample collections); Reader: $\$ 5500$

Additional costs: None

Shelf- life: 2 years for abrin and ricin assays, 3 years for all others. sample volume is applied to the test strip). In 2004, the EPA ETV program evaluated the BioThreat Alert $^{\circledR}$ test strips for the detection of botulinum neurotoxin, anthrax, and ricin (weblink to report listed in the References). Detection limits varied based on the spore preparation (Dugway live spores (700 million spores $/ \mathrm{mL}$ ) vs. Battelle phenol-preserved spores (80 million spores $/ \mathrm{mL})$ ). Calcium $(230 \mathrm{mg} / \mathrm{L})$ and magnesium $(90 \mathrm{mg} / \mathrm{L}$ ) were found to inhibit the anthrax assay; however, calcium and magnesium were not found to interfere with the assays for ricin and botulinum neurotoxin. 


\section{References}

Evaluation of lateral flow assays for the detection of botulinum neurotoxin type $A$ and their application in laboratory diagnosis of botulism. Diagnostic Microbiology and Infectious Disease (2007) 57:243-249. This study found the assay did not detect purified botulinum neurotoxin A in the highest concentration samples tested $(1,000 \mathrm{ng} / \mathrm{mL})$; however, the toxin in complex with its natural, nontoxic carrier proteins was detected at $10 \mathrm{ng} / \mathrm{mL}$.

Evaluation of Lateral-Flow Clostridium botulinum Neurotoxin Detection Kits for Food Analysis. Applied and Environmental Microbiology (2005) 71(7):3935-3941. This paper reports the sensitivity for detecting botulinum neurotoxin type $\mathrm{A} / \mathrm{B}$ to be $10 \mathrm{ng} / \mathrm{mL}$ and type $\mathrm{E}$ to be $20 \mathrm{ng} / \mathrm{mL}$. This report cites the Alexeter assays, which were originally manufactured by Tetracore for Alexeter but currently, are sold exclusively by Tetracore.

\section{Environmental Technology Verification (ETV) Report for BioThreat Alert ${ }^{\circledR}$ Anthrax,} Botulinum Toxin, and Ricin Immunoassay Test Strips. Testing performed by Battelle between January 14 and April 23, 2004. http://www.epa.gov/etv/pubs/01_vr_biothreat.pdf 


\subsection{PCR-Based Detection Systems}

PCR-based assays detect specific organisms based on their DNA sequence. During PCR, protein polymerases copy short pieces of DNA-millions of DNA copies are generated from just a few hundred starting molecules. The assay is designed so only regions of DNA that are unique to the target organism(s) are amplified.

Most field-based PCR systems consist of a disposable assay cartridge containing all of the consumable reagents (including the required polymerase), an instrument that integrates the thermal components required to perform the heat/cool cycles required for PCR, and the optical components required to quantify the amplified DNA products. PCR assays are performed on liquid samples and require a sampling

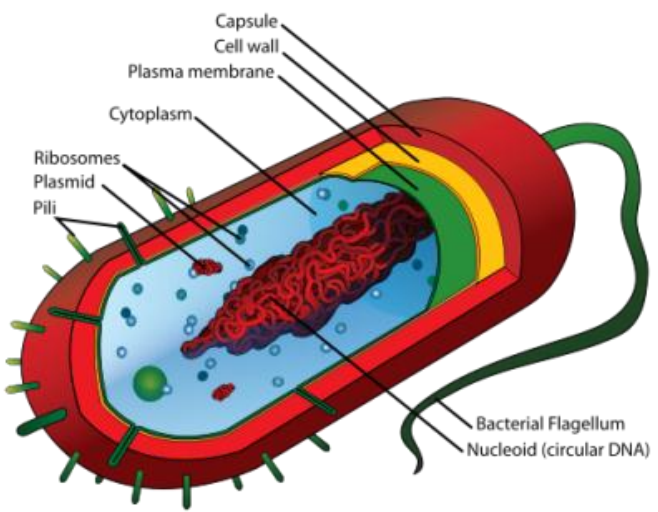

Illustration of a bacterial cell. All cells and viruses contain DNA or RNA that can be used to detect and identify them. (By Mariana Ruiz Villarrea (Average_prokaryote_cell-_en.svg) [Public domain], via Wikimedia Commons) kit to swab a suspicious powder and solubilize the white powder in a buffer compatible with PCR. Sample (white powder + buffer) is added to the assay cartridge and, depending on the system, other manual steps may be required before the cartridge is placed in the instrument. In the instrument, the sample and reaction mixture is cycled between high and low temperatures to amplify the target DNA and the dye-labeled product DNA is measured by integrated optical components (usually fluorescence-based). Each thermal cycle doubles the amount of DNA available for detection; for example, 10 DNA molecules increase to 20 , then 40 , then 80 in three cycles. An assay typically contains an internal positive control to ensure the system components are performing as specified.

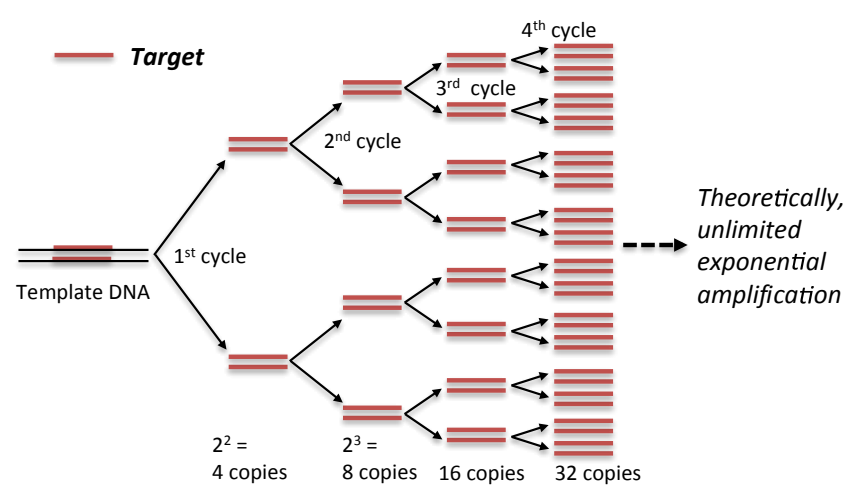

PCR can Amplify a Single Piece of DNA to make Millions of Copies in less than 20 Thermal Cycles

(By Andy Vierstraete (PCRcopies.gif) Yi Cou derivative work (CH391L_S12_PCR_exponential_amplification.jpg) [Public Domain], via OpenWetWare)
PCR-based assays are advantageous because they are very sensitive and specific (although the specificity of a system is dependent on the design of a particular assay). Few field-based PCR systems have integrated sample preparation to concentrate DNA and remove PCR inhibitors; but, because PCR is very sensitive, a sample can often be significantly diluted after sampling to reduce the effects of the inhibitors on the reaction. The most significant disadvantages of PCR-based assays are cost (instruments range from $\$ 15$ to $50 \mathrm{~K}$ and assays from $\$ 12$ to 200) and long assay times (30 to 60 minutes). PCR assays will not detect toxins, unless the toxin preparation contains DNA from the source organism (i.e., castor bean DNA in a preparation of ricin toxin). 
When presented with several current commercially available hand portable PCR-based systems from Smiths Detection, BioFire Diagnostics (formerly Idaho Technology), and Tetracore, the overwhelming response from the first responders in our recent survey was that none of the systems were user-friendly for a responder wearing a Level A suit. Most of the current systems have preparative steps requiring manual dexterity and visual acuity that would be challenging when the user is fully suited up for a biological threat response. However, most potential biothreat responses are conducted in Level B suits, making some systems easier to use, though still not ideal.

\section{Hand Portable PCR-based Systems}

- Assay cost: $\$ 12$ to 200

- Reader cost: $\$ 16$ to $45 \mathrm{~K}$

- Examples: Bio-Seeq ${ }^{\mathrm{TM}}$ PLUS (Smiths Detection), T-COR 4 ${ }^{\mathrm{TM}}$ (Tetracore), RAZOR ${ }^{\circledR}$ EX (BioFire Diagnostics, formerly Idaho Technology), and FilmArray ${ }^{\circledR} *$ (BioFire Diagnostics)

* The FilmArray ${ }^{\circledR}$ system is AC powered, not currently ruggedized, and is more suitable for a mobile laboratory setting 


\section{BioFire Diagnostics (formerly Idaho Technology): FilmArray ${ }^{\circledR}$}

Website: http://www.biofiredx.com

Contact: Lou Banks, Biodefense Marketing Manager (Lou.Banks@biofiredx.com)

Phone: (801) 736-6354

\section{Technology Summary}

The FilmArray ${ }^{\circledR}$ is a fully automated multiplexed PCR-based platform. The system consists of four components: the loading station, reagent pouch, instrument/reader, and laptop computer (see figure).

After injecting a hydration solution and the sample, all preparation, extraction, amplification, and detection steps are automated. The sample passes through a series of chambers within the reagent pouch. In the first chamber, cells/spores are lysed with ceramic beads and a lysis solution. The next set of chambers purifies and concentrates the nucleic acids using magnetic beads. In the last chamber, RNA is reverse transcribed into cDNA and the first round of multiplexed PCR amplification is performed. The sample is then diluted and partitioned into 120 separate $1 \mu \mathrm{L}$ reaction wells, each containing reagents and a target-specific primer pair for a second stage singleplex PCR. In addition, each well contains a fluorescent probe that binds to double-stranded DNA. A patented post-PCR, high-resolution melting point analysis is used to identify positive

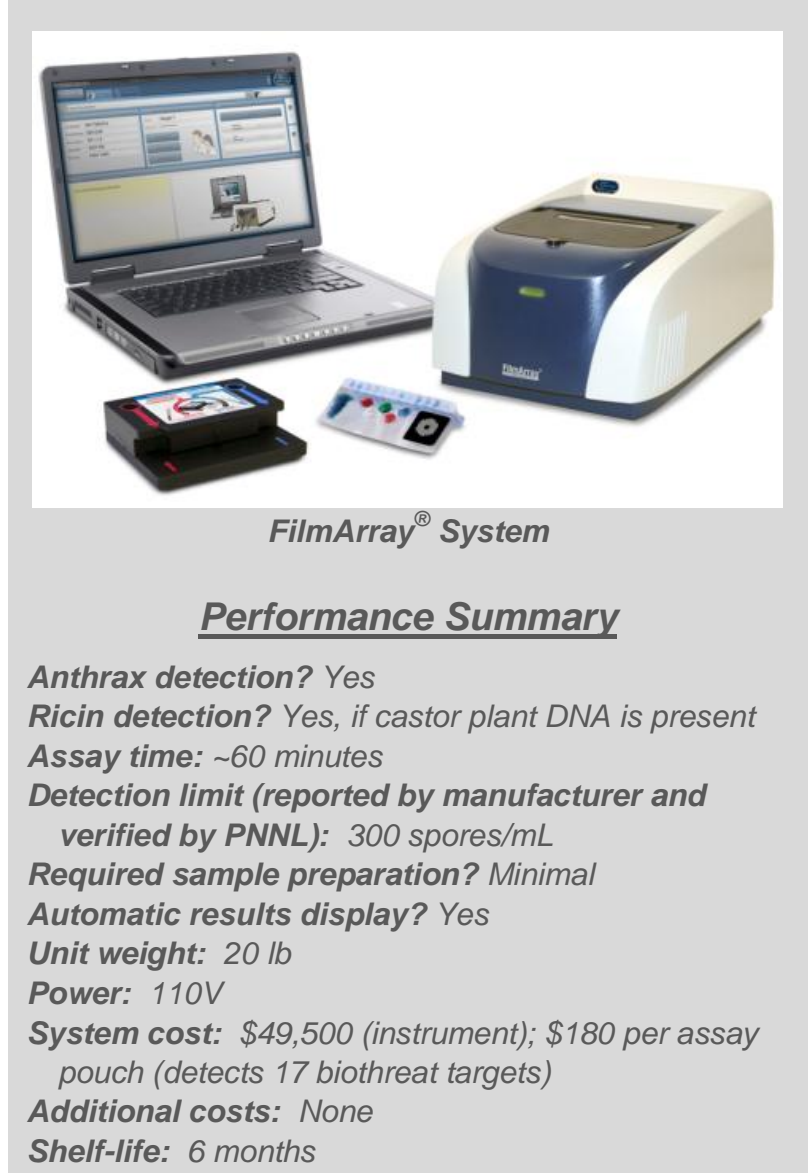
Shelf-life: 6 months targets by monitoring the fluorescence quenching of a double-stranded DNA binding probe. The melting curve is dependent on the length, DNA composition and degree of complementarity of the duplex DNA. Software integrates the results from replicate samples and multiple signatures to determine if a sample is reported as positive or negative.

\section{Demonstrated Biodetection Assays}

BioFire Diagnostics (BFDx) has a biothreat panel (not currently advertised) pouch that simultaneously tests a single sample for the presence of 27 targets (17 agents): B. anthracis (3 targets), Ebola virus, Variola virus, Burkholderia mallei/pseudomallei, Francisella tularensis (2 targets), VEE virus (2 targets), Rickettsia prowazekii (2 targets), Staphylococcus aureus, Clostridium botulinum, Marburg virus (2 targets), Y. pestis (2 targets), Brucella species (2 targets), Coxiella burnetii (2 targets), EEE virus, orthopox (2 targets), Ricinus communis, and WEE virus. BFDx reports a sensitivity for anthrax spores to be 300 spores/mL ( 90 spores, assuming a $300 \mu \mathrm{L}$ sample (recommended by BFDx is diluted into the reaction buffer). Initial testing of the FilmArray ${ }^{\circledR}$ biothreat pouch by PNNL for detection 
of B. anthracis, Francisella tularensis, and $Y$. pestis genomic DNA samples supports the sensitivity claims of the manufacturer.

\section{References}

Evaluation of the Idaho Technology FilmArray ${ }^{\circledR}$ system for detection of Bacillus anthracis, Francisella tularensis, and Yersinia pestis. Journal of Applied Microbiology (first published online January 31,21013$)$. Evaluation of the FilmArray ${ }^{\circledR}$ Biothreat panel with purified DNA samples at PNNL. Sensitivity is reported to be 250 DNA copies.

Evaluation of two multiplex real-time PCR screening capabilities for the detection of Bacillus anthracis, Francisella tularensis and Yersinia pestis in blood samples generated from murine infection models. J Med Microbiol. 2012 Nov;61(Pt 11):1546-55. Evaluation of the FilmArray Biothreat panel for the detection of Bacillus anthracis in blood of infected mice. The FilmArray assay was found to have similar detection rates as culture.

The FilmArray ${ }^{\circledR}$ system has been FDA-approved for use with the respiratory panel assay cartridge (note: not the Biothreat panel) and has been evaluated in three separate studies using clinical samples as reported below. The respiratory panel was both sensitive and selective in detecting several different respiratory viruses in these evaluations.

Comparison of the Luminex xTAG RVP Fast Assay and the Idaho Technology FilmArray ${ }^{\circledR}$ RP Assay for Detection of Respiratory Viruses in Pediatric Patients at a Cancer Hospital. Journal of Clinical Microbiology 50 (2012) 2282-2288.

Comparison of two broadly multiplexed PCR systems for viral detection in clinical respiratory tract specimens from immunocompromised children. Journal of Clinical Virology 53 (2012) 308-13.

Comparison of the Idaho Technology FilmArray ${ }^{\circledR}$ system to real-time PCR for detection of respiratory pathogens in children. Journal of Clinical Microbiology 50 (2012) 364-71. 


\section{BioFire Diagnostics (formerly Idaho Technology): R.A.P.I.D. ${ }^{\circledR}$}

Website: http://www.biofiredx.com

Contact: Lou Banks, Biodefense Marketing Manager (Lou.Banks@ biofiredx.com)

Phone: (801) 736-6354

\section{Technology Summary}

Ruggedized Advanced Pathogen

Identification Device (R.A.P.I.D. ${ }^{\circledR}$ ) is a portable real-time PCR system. A military version of this system (JBAIDS) is available exclusively to the U.S. Department of Defense. R.A.P.I.D. ${ }^{\circledR}$ integrates BioFire Diagnostics' (BFDx) LightCycler $^{\circledR}$ instrument technology into a rugged, portable enclosure that fits in a backpack. A laptop computer and sample preparation materials (e.g., vortexer, microfuge, pipettes, racks, wipes) are also included in the backpack. The system requires a 110 or $220 \mathrm{~V}$ power source for operation.

The system is highly configurable-it can use stock assays and reagents developed by BFDx or independent assays defined by the user. In addition, it is possible to multiplex four signatures in one reaction. Up to 32 samples can be analyzed in parallel in less than 30 minutes, not including sample preparation. Sample preparation is performed offline and can take up to an additional 1.5 hours. Considering the extensive offline sample preparation and external power requirements, this system is well-suited for use in a mobile analytical laboratory or field hospital with trained personnel.

\section{Demonstrated Biodetection Assays}

R.A.P.I.D. ${ }^{\circledR}$ is compatible with standard real-

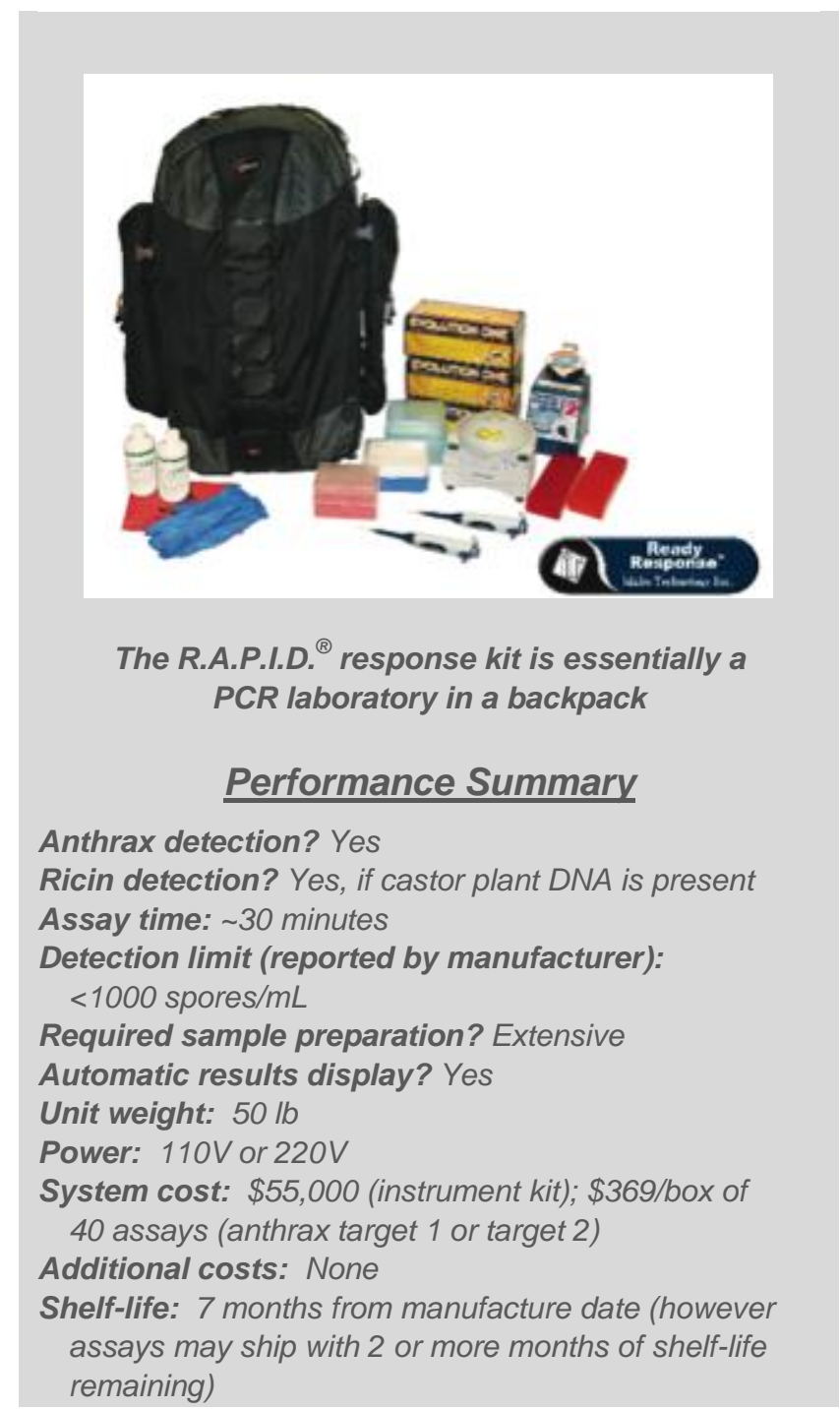

Anthrax detection? Yes

Ricin detection? Yes, if castor plant DNA is present Assay time: 30 minutes

Detection limit (reported by manufacturer):

$<1000$ spores/mL

Required sample preparation? Extensive

display? Yes

Power: $110 \mathrm{~V}$ or $220 \mathrm{~V}$

System cost: $\$ 55,000$ (instrument kit); $\$ 369 /$ box of A0 assays (anthrax target 1 or target 2)

Additional costs: None assays may ship with 2 or more months of shelf-life

time PCR assays. All of BFDx's biothreat assays can be run on R.A.P.I.D. ${ }^{\circledR}$ (including the 'Biothreat 10 panel'). In a limited evaluation performed in 2004 by the U.S. EPA (weblink to the report provided in the References), the anthrax test was found to detect $2000 \mathrm{CFU} / \mathrm{mL}$ consistently with the R.A.P.I.D. ${ }^{\circledR} B$. anthracis targets 1,2, and 3 assays. Assuming a sensitivity of less than 1000 spores $/ \mathrm{mL}$, the B. anthracis assays can detect 20 organisms, assuming a $20 \mu \mathrm{L}$ extracted DNA sample is used. Commercial assays are available for the following targets: anthrax, botulinum toxin, E. coli 0157, ricin, smallpox, Brucellosis (Brucella spp), tularemia, salmonella, and plague. 


\section{References}

Idaho Technology Inc. R.A.P.I.D. ${ }^{\circledR}$ System for the Detection of Francisella tularensis, Yersinia pestis, Bacillus anthracis, Brucella suis, and Escherichia coli. EPA Environmental Technology

Verification Report 2004. Evaluation of R.A.P.I.D. ${ }^{\circledR}$ for detection of potential bioterror agents in drinking water. Sensitivity for B. anthracis was found to be $2000 \mathrm{CFU} / \mathrm{mL}$ using the Idaho Technology 1-2-3 Flow Kit for sample preparation and R.A.P.I.D. ${ }^{\circledR}$ B. anthracis targets 1,2 , and 3 assays.

Environmental Technology Verification (ETV) Report for Idaho Technology Inc., R.A.P.I.D. System for the detection of Francisella tularensis, Yersinia pestis, Bacillus anthracis, Brucella suis, and Escherichia coli. Testing performed by Battelle between May 27 and July 8, 2004.

www.epa.gov/etv/pubs/01_vr_rapid.pdf 


\section{BioFire Diagnostics (formerly Idaho Technology): RAZOR ${ }^{\circledR}$ EX}

Website: http://www.biofiredx.com

Contact: Lou Banks, Biodefense Marketing Manager (Lou.Banks@ biofiredx.com)

Phone: (801) 736-6354

\section{Technology Summary}

The RAZOR ${ }^{\circledR}$ EX is PCR-based system for pathogen detection in the field. The RAZOR ${ }^{\circledR} \mathrm{EX}$ system is packaged in an over-the-shoulder carrying case weighing $11 \mathrm{lb}$. The system includes a rechargeable internal battery pack that can power the system for eight assays. The system has been extensively tested for field use (e.g., temperature, humidity, vibration, and drop tests) and is currently being employed by a wide range of first responders (e.g., police and fire departments) and friendly governments (e.g., Malaysia, France, Spain, and Germany).

The system performs PCR on a crude sample solubilized from a swab. Typically, a single sample is input into the "reagent pouch," which contains all the assay reagents (e.g., primers, probes, enzymes, and buffers) needed for the PCR reaction. The system performs minimal sample preparation in the form of sample dilution to reduce the effects of possible PCR inhibitors and thermal disruption of cells and viruses. No additional cleanup of the sample is performed. In preparing the pouch for a run, there are several required manual preparative steps that involve fine manual dexterity. Within the pouch, the sample is split among 12 channels for 12 independent PCR assays. For the BioThreat 10 panel, 10 of the channels are used for pathogen detection (1 signature per channel) with the remaining 2 channels used for control reactions to

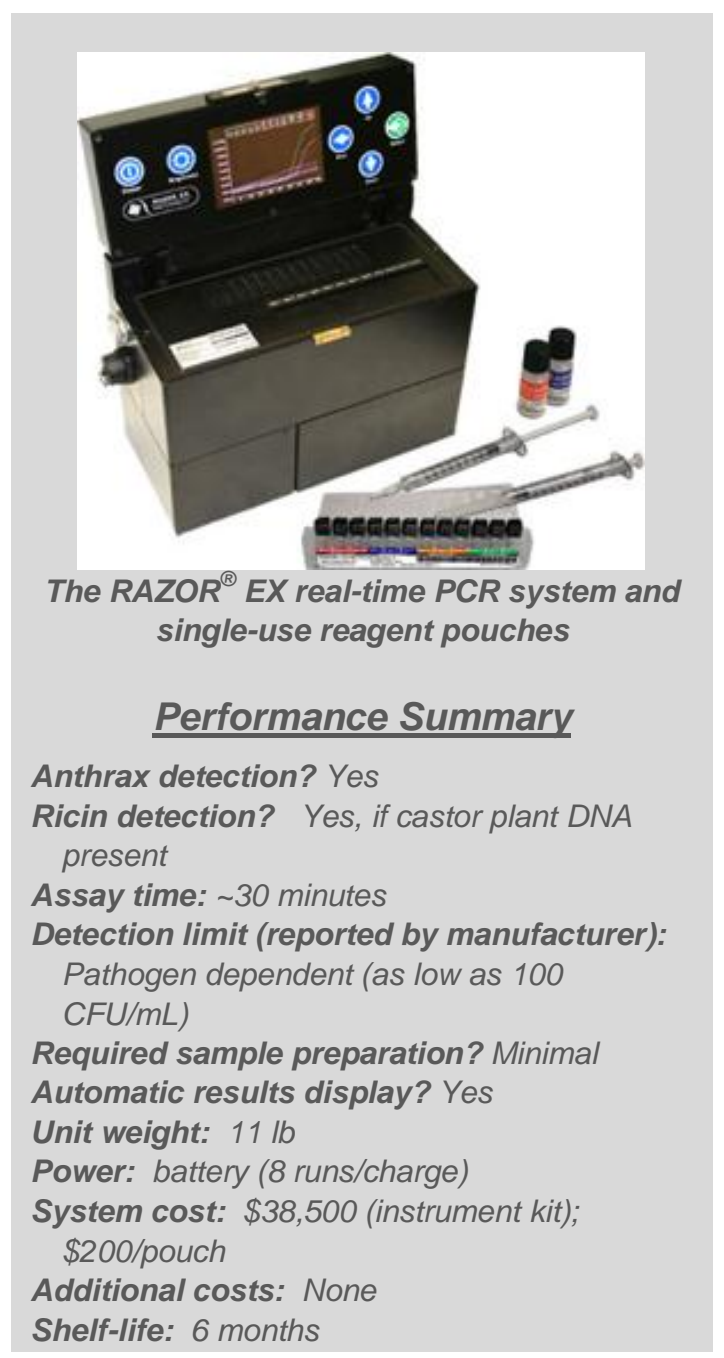
measure the effect of inhibitors that may be present in a sample. If the sample contains PCR inhibitors, the user is directed to dilute the sample and re-run the assay. Each instrument run takes approximately 30 minutes.

\section{Demonstrated Biodetection Assays}

BFDx reports a sensitivity of as low as $100 \mathrm{CFU} / \mathrm{mL}$ for anthrax spores, which corresponds to 50 or 200 spores depending on the sample volume (the BA-3 pouch requires $0.5 \mathrm{~mL}$, while the 10 -threat pouches require a $2 \mathrm{~mL}$ sample). Biothreat assays have been evaluated by end-users in Australia, Canada, and Spain (testing sponsored by BFDx and reported on the BFDx website). The Biothreat 10 target screen kit tests for B. anthracis, Brucella, Coxiella, E. coli, Francisella tularensis, Salmonella, Y. pestis, smallpox, ricin toxin, and botulinum toxin. In addition, the RAZOR ${ }^{\circledR}$ platform has been independently evaluated in a Department of Homeland Security-sponsored Stakeholder Panel on Agent Detection 
Assays (SPADA) (referenced below) for the analysis of extracts from aerosol collection filters and with manual sample preparation done prior to PCR analysis. This extensive testing found that 2473 of 2479 samples tested provided the expected results (99\% success with $95 \%$ confidence). Unfortunately, the anthrax assay evaluated in these studies is not commercially available, so the applicability of these results to the currently distributed assay is unknown.

\section{References}

Razor $^{\circledR}$ EX Anthrax Air Detection System. Journal of AOAC International 95(3) (2012) 860-891. This reference summarizes the AOAC Method Developer and Independent Laboratory Validation studies for the RAZOR ${ }^{\circledR}$ EX Anthrax Air Detection System. The system could reliably detect $1 \mathrm{pg} / \mathrm{reaction}$ volume of B. anthracis, which is equivalent to $2000 \mathrm{spores} / \mathrm{mL}$. Unfortunately, these test pouches are not currently commercially available, so the applicability of this study to the commercially available B. anthracis assays is unknown. 


\section{Smiths Detection: Bio-Seeq ${ }^{\mathrm{TM}}$ PLUS}

Website: http://www.smithsdetection.com

Contact: Ken Klein, Bio-ID Product Manager (ken.klein@ smithsdetection.com)

Phone: (203) 207-9700

\section{Technology Summary}

The Bio-Seeq ${ }^{\mathrm{TM}}$ PLUS is a hand portable PCR instrument that includes a battery for operation in the field. The Bio-Seeq ${ }^{\text {TM }}$ PLUS uses cartridges that contain a single target assay and a control assay. Six assay cartridges can be run simultaneously on the instrument. The system relies on thermal stress to disrupt cells/spores during the assay; no specific lysis or DNA sample preparation is performed.

Visual acuity and manual dexterity are required to process samples. After sampling a white powder, a fixed pipettor (provided) is used to pipette $40 \mu \mathrm{L}$ of sample into the bottom half of a thimble-sized cartridge. The top half of the cartridge is then screwed on the bottom half, and the cartridge is shaken to mix the reagents. The cartridge is then flicked with a snapping wrist motion to move the solution down into the attached cuvette. The cartridge is placed into one of the six ports of the instrument and a run is initiated. Test results are reported as positive, negative, or indeterminate (requires re-reading of the fluorescence signal).

\section{Demonstrated Biodetection Assays}

The Bio-Seeq ${ }^{\mathrm{TM}}$ PLUS has commercially available cartridges, updated in Spring 2012, that include a new sampling protocol. Commercial assays are available for anthrax (pXO1), anthrax (pXO2), smallpox, tularemia, and plague. The company claims LODs of 3000 to $4000 \mathrm{copies} / \mathrm{mL}$ for these assays (120 to 160

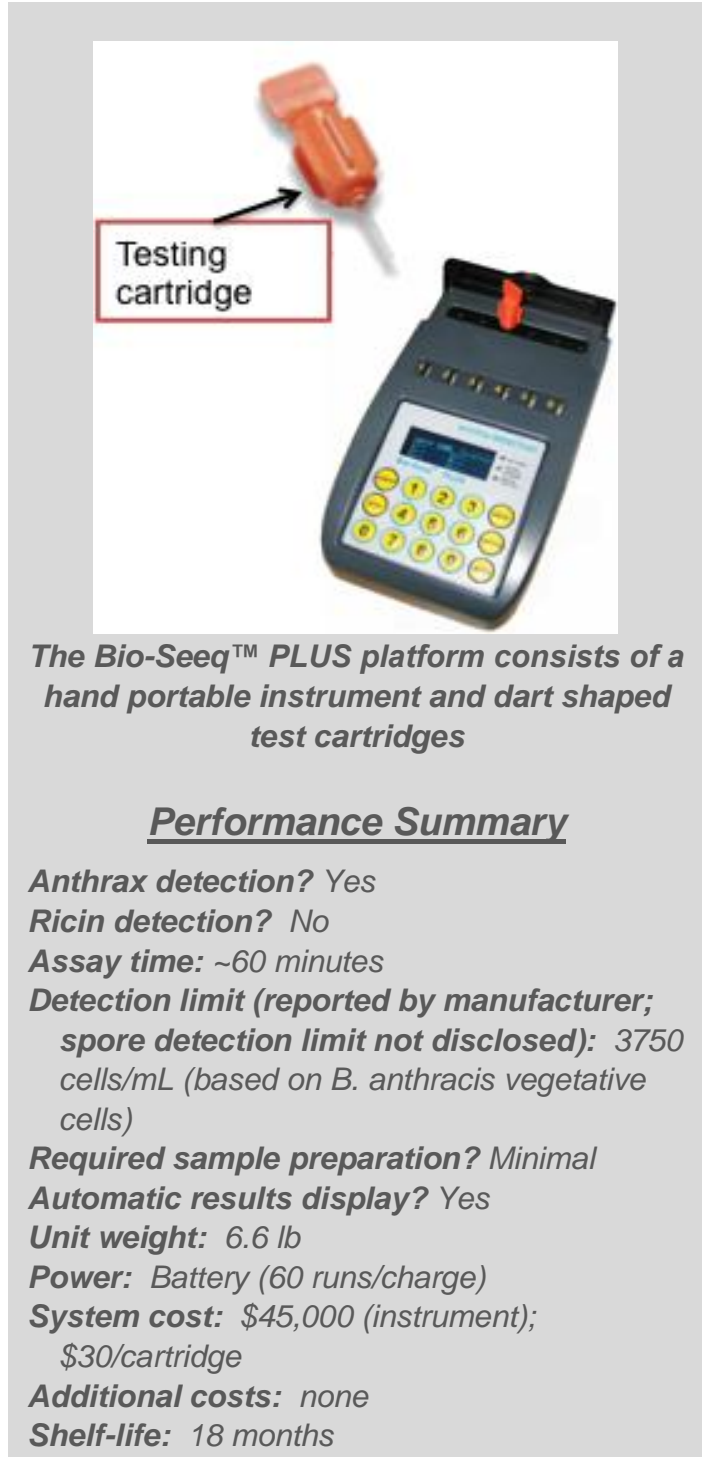
anthrax spores assuming a $0.04 \mathrm{~mL}$ sample). An evaluation of the previous version of the Bio-Seeq assays, sponsored by Smiths and performed at ECBC, demonstrated the pXO1 assay for anthrax could reliably detect 150 genome equivalents of purified DNA from B. anthracis Sterne strain (report available upon request from Smiths, see References). This study also found the $\mathrm{pXO} 2$ assay could reliably detect 23,000 genome equivalents for purified DNA from B. anthracis Pasteur strain. This detection limit was higher than expected; the loss of sensitivity was attributed to suboptimal reagents provided for testing. 


\section{References}

Detection of Francisella tularensis within Infected Mouse Tissues by Using a Hand-Held PCR Thermocycler. Journal of Clinical Microbiology (2003) 41:689-93. This reference describes the detection of Francisella tularensis DNA using the original Bio-Seeq ${ }^{\mathrm{TM}}$ instrument and reports a detection limit 200 to $300 \mathrm{fg}$ of purified DNA, which is equivalent to approximately 100 to 150 genome equivalents. The same assays were 4 to 6 fold more sensitive when performed on a laboratory-based realtime PCR instrument (ABI 7900).

Evaluation of LATE-PCR Assays for the Identification of Biological Agents using the BioSeeq Plus. Test Analysis Report. (not peer reviewed) Report compiled by US Army Edgewood Chemical Biological Center, Biophysical Chemistry and Biodefense Branches. February 5, 2009. Available upon request from Smiths Detection. 


\section{Tetracore: $\mathrm{T}-\mathrm{COR} 4^{\mathrm{TM}}$}

Website: http://www.tetracore.com/t-cor/index.html

Contact: Pete Pillay (ppillay@tetracore.com)

Phone: (204) 268-5400

\section{Technology Summary}

The Tetracore T-COR $4^{\mathrm{TM}}$ is a hand portable, battery-powered PCR instrument. The system is capable of running four independent samples simultaneously. However, only two detection channels are available for each assay; therefore, typically only one target and one internal positive control assay are performed in each assay tube. The instrument kit includes a small, batteryoperated centrifuge (pictured) used during the sample preparation.

Sample preparation is not intensive; however, visual acuity and manual dexterity are required. After sampling and solubilizing a suspicious powder with a sampling kit (not provided), $30 \mu \mathrm{L}$ of sample is transferred into the assay tube. The assay tube is briefly centrifuged to remove bubbles and the tube is then pinched between the thumb and forefingers 8 to 10 times to ensure proper mixing. Finally, the tube is placed into the instrument and the run is initiated.

\section{Demonstrated Biodetection Assays}

Tetracore has developed assays to test for a variety

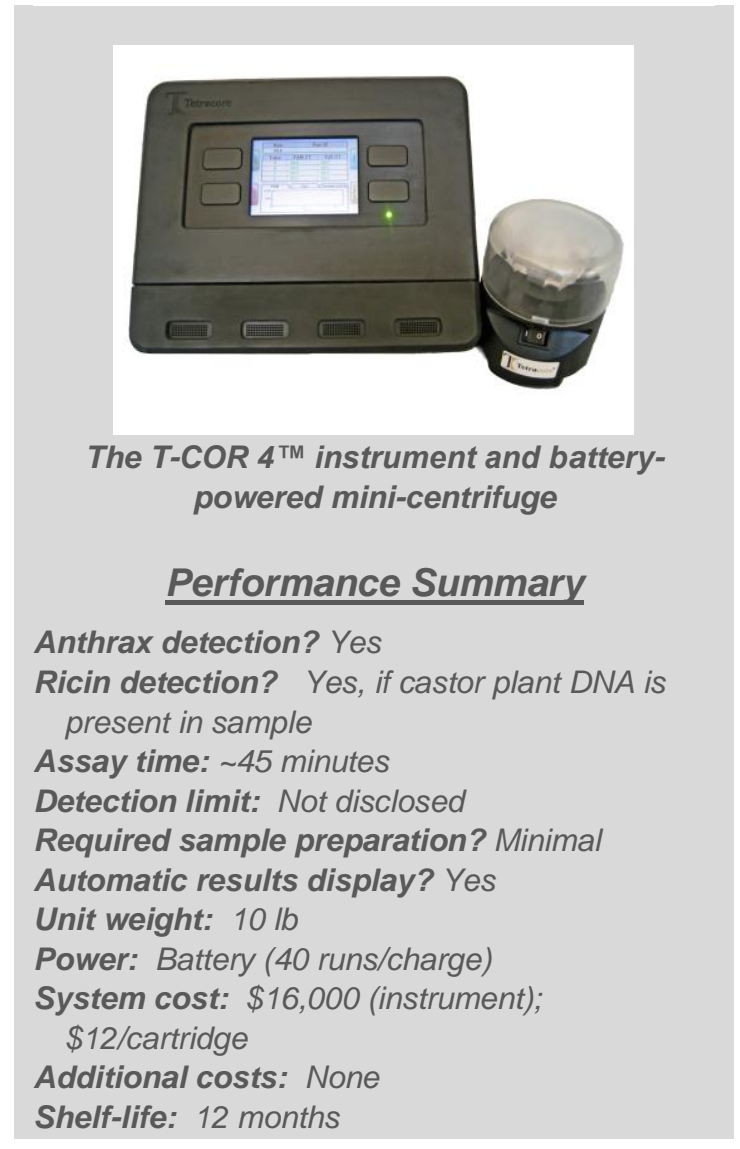
of bioagents and the respective diseases they cause, including anthrax, SEB, plague, ricin, tularemia, and botulinum.

\section{References}

No publicly available, peer-reviewed references were found for this product. 



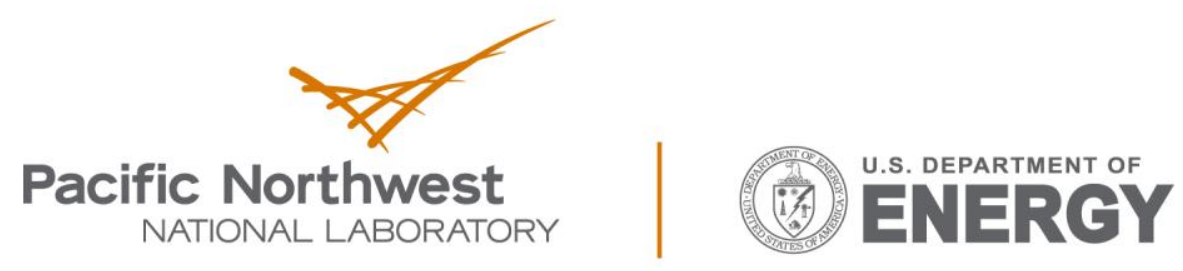

Proudly Operated by Battelle Since 1965

902 Battelle Boulevard

P.O. Box 999

Richland, WA 99352

1-888-375-PNNL (7665)

www.pnnl.gov 